\title{
Flaxseed Lignans as Important Dietary Polyphenols for Cancer Prevention and Treatment: Chemistry, Pharmacokinetics, and Molecular Targets
}

\author{
S. Franklyn De Silva *(D) and Jane Alcorn*(D) \\ Drug Discovery \& Development Research Group, College of Pharmacy and Nutrition, 104 Clinic Place, \\ Health Sciences Building, University of Saskatchewan, Saskatoon, SK S7N 2Z4, Canada \\ * Correspondence: f.desilva@usask.ca (S.F.D.S.); jane.alcorn@usask.ca (J.A.); Tel.: +1-306-966-6365 (J.A.)
}

Received: 22 March 2019; Accepted: 30 April 2019; Published: 5 May 2019

\begin{abstract}
Cancer causes considerable morbidity and mortality across the world. Socioeconomic, environmental, and lifestyle factors contribute to the increasing cancer prevalence, bespeaking a need for effective prevention and treatment strategies. Phytochemicals like plant polyphenols are generally considered to have anticancer, anti-inflammatory, antiviral, antimicrobial, and immunomodulatory effects, which explain their promotion for human health. The past several decades have contributed to a growing evidence base in the literature that demonstrate ability of polyphenols to modulate multiple targets of carcinogenesis linking models of cancer characteristics (i.e., hallmarks and nutraceutical-based targeting of cancer) via direct or indirect interaction or modulation of cellular and molecular targets. This evidence is particularly relevant for the lignans, an ubiquitous, important class of dietary polyphenols present in high levels in food sources such as flaxseed. Literature evidence on lignans suggests potential benefit in cancer prevention and treatment. This review summarizes the relevant chemical and pharmacokinetic properties of dietary polyphenols and specifically focuses on the biological targets of flaxseed lignans. The consolidation of the considerable body of data on the diverse targets of the lignans will aid continued research into their potential for use in combination with other cancer chemotherapies, utilizing flaxseed lignan-enriched natural products.
\end{abstract}

Keywords: flaxseed lignans; dietary polyphenols; phytochemicals; cellular/molecular targets; pharmacokinetics; chemopreventive; chemotherapeutic; hallmarks of cancer; quality of life

\section{Introduction}

The exploration of alternative strategies for cancer prevention and treatment has become necessary owing to the high costs of current chemotherapies, prolonged time in regulatory authorization processes for new cancer treatments, and the considerable expenditure associated with taking a medicinal agent from bench to bed-side. Repositioning of noncancer therapeutics, such as plant polyphenols, to treat cancer offers an alternate strategy to address these challenges. Such therapeutic interventions are usually associated with lower costs and manageable toxicity with concomitant improvement in quality of life. Plant polyphenols have a long history of proposed benefits in the prevention and treatment of a chronic disease like cancer [1-4]. Although the evidence for health benefits of plant polyphenols is available throughout the literature, the flaxseed polyphenols have gained increasing attention. Flaxseed contains numerous nutrient and non-nutrient chemical constituents, like $\alpha$-linolenic acid, fiber, and lignans, which can support our well-being [5-20]. More recently, polyphenols of flaxseed-the lignans-have sparked increased interest mostly attributing to their antioxidative, anti-inflammatory, anti-atherosclerogenic, and antiestrogenic potential, thus suggesting ability to reduce risk and protect against cancer [16,21-38]. Such attributes have compelled expansion of investigations into lignan mechanisms of action. 
Plant lignans [39], different from lignins (racemic polymers that are components of the plant cell wall $[39,40])$, are non-nutrient, noncaloric, bioactive phenolic plant compounds [39]. Diverse lignanoid constituents from plant-based food resources [41], like secoisolariciresinol diglucoside (SDG) [42], lariciresinol [41], isolariciresinol [43], 7-hydroxymatairesinol [44], matairesinol (MAT) [45], pinoresinol, arctigenin, syringaresinol [46], and asarinin [47], can be precursors of enterolignans-the mammalian-derived lignans-following oral consumption of plant lignans [39]. The primary intent of this review is to consolidate the evidence of lignan pharmacokinetics and modulation of cellular processes and cell signaling pathways within the cancer phenotype so as to provide opportunity to direct future investigations into the role and benefit of the dietary polyphenols, specifically flaxseed lignans, in the prevention and treatment of cancer (i.e., complementary and integrative medicine [48]).

\section{Growing Use of Naturally Derived Products}

Unsatisfactory results of Western medicine have given complementary and alternative treatment options more attention [49]. Many patients rely on phytochemicals and herbal medicines (collectively referred to as natural health products (NHPs) for the purpose of this review) for primary health care, especially in the developing world [50]. In developed countries, NHPs are used to promote healthier living [50]. Although several NHPs have promising effects with wide utilization, some remain untested with clinical use unmonitored and undocumented [50], while some NHPs have safety concerns [51]. Existence of a regulatory framework for NHPs provides greater reassurance to consumers; however, regulations and product quality specification vary among countries [49]. As an example, the Dietary Supplement Health and Education Act (DSHEA) of 1994 provided the U.S. FDA the authority to implement Good Manufacturing Practices (GMP) for dietary supplements and ensure safety of such products, and the framework of the Federal Food, Drug, and Cosmetic Act, which led to the DSHEA, provides the necessary framework needed by the Food and Drug Administration (FDA) to regulate dietary supplements [52]. Additionally, in Canada, NHPs approved by Health Canada (e.g., herbal remedies [53]) are regulated under the Natural and Non-Prescription Health Products Directorate [54]. This allows for large production and lower prices (due to competition) by companies, even though NHPs are regulated somewhat similar to pharmaceutical drugs under the Natural Health Products Regulation (NHPR). These regulations protect Canadians by ensuring that the products obtained meet their health needs $[55,56]$. Regardless of the preclinical evidence of NHPs, translational capabilities into the clinic can be hampered by similar factors encountered by drugs in development such as the dose size and dosage forms and the variability in outcomes caused by gender, ethnicity, and comorbidities [55].

\section{Cancer, the Unmet Medical Need}

Cancer was identified as an important human disease thousands of years ago [57]. In the subsequent thousands of years cancer patients faced little hope for cure and survival, a situation unchanged for some cancers and clearly an unmet medical need for these patients. Globally, cancer contributes to considerable mortality with estimates projected to increase from 14 million new cases per year in 2012 [2] to an estimated 19.3 million cases yearly by 2025 [58,59]. Colorectal, liver, breast, gastric, prostate, cervical, and lung cancers remain the principal causes of cancer deaths [2], and the majority of cancer related mortality occurs in low- and middle-income countries [60,61]. Surgery, radiotherapy, and systemic therapy, which include general chemotherapy, hormonal therapy, immunotherapy, and targeted therapies, are the current treatments of cancer [58]. In too many patients these treatments fail, and cancer remains a major challenge to clinical interventions. A need exists to discover more effective ways of targeting cancer and new avenues of disease management might offer some potential.

Today's improved understanding of the characteristics of cancer offer renewed hope for treating cancer. The pioneering work of Weinberg and colleagues to categorize the cancer characteristics into distinct tumor properties, the so-called "Hallmarks of Cancer", provide a framework around which to rally the considerable scientific and technological advances to identify more effective treatments 
for different cancer phenotypes [62,63]. Among the different cancer characteristics, mutations enable malignant cells both continuity and survival. These driver mutations stem from various mechanisms including carcinogen exposure [57]. Carcinogenesis is a complex multifactorial and multistep process separated into three closely related stages: initiation, promotion, and progression [64-67] (Figure 1). The first stage, initiation, follows usually from carcinogen (or its metabolite) exposure and is traditionally considered an irreversible step with one or more genetic alterations resulting from DNA mutations, transitions, transversions, or deletions [65,68]. Promotion is the second stage and is considered a reversible stage where the proliferation of neoplastic cells takes prominence [65]. This stage does not involve DNA structural changes but rather changes in genome expressions brought out by promoter-receptor interactions [68]. Tumor progression is the last stage where neoplastic transformation occurs followed by tumor growth, invasion, and metastasis [65]. Stages of carcinogenesis are governed by proto-oncogenes, cellular oncogenes, and tumor suppressor genes. These genes and their protein products may serve as druggable targets for cancer treatment.

In order to reduce the incidence and mortality of different malignancies, effective preventive strategies that impede tumorigenesis are needed [69]. Although the heterogeneity of tumors and tumor development may pose a challenge for successful therapeutic interventions [70], the initial stages of carcinogenesis is usually associated with a lower burden of molecular and cellular aberrations such that chemopreventive or early chemotherapy is more likely to achieve therapeutic efficacy as compared with treatment of more advanced stages of tumorigenesis [70]. Furthermore, it is well known that cancer development and progression is associated with inflammation. Hence, early preventive or treatment strategies should include anti-inflammatory therapies. While recruitment and activation of inflammatory cells due to mutations that initiate cancer may trigger cancer-intrinsic inflammation, a multitude of factors (e.g., toxin exposure, microbial infections, autoimmune disease, and obesity) are responsible for cancer-extrinsic inflammation [71]. Epidemiologic studies reveal that $\sim 20 \%$ of all cancers emerge as a direct result of long-standing inflammatory disease [71-73]. For these reasons inflammation is a frequent mechanism of action for diverse cancer risk factors [71]. Therefore, various anti-inflammatory agents such as selective cyclooxygenase- 2 inhibitors, nonsteroidal anti-inflammatory drugs, and natural health products with anti-inflammatory properties have been identified as potential chemopreventive agents $[69,71,74-79]$.

\section{Cancer Prevention}

The sequence of events in the multistage process of carcinogenesis provides opportunities for intervention with the goal of preventing, reversing, or delaying tumor development and progression [80]. Interventions generally fall into three categories of prevention, namely primary (preventing disease or injury), secondary (reducing impact of disease or injury), and tertiary (reducing impact of ongoing disease or injury having lasting consequences) [81-88]. These categories are based on the concept of chemoprevention first proposed in the early 1970s by Sporn [85,89], and extended by Wattenberg, who suggested the selective inhibition of carcinogenesis in any of the phases of cancer-initiation, promotion, or progression $[90,91]$. Primary chemopreventives block the disease by inhibiting mutagenesis, cancer initiation, and tumor promotion [65]. During early stages of tumorigenesis, secondary chemopreventive agents inhibit tumor progression by interfering with signal transduction, hormones, angiogenesis, antioxidant activity, and immune status [65]. The third class promotes chemoprevention by blocking cancer invasion and metastasis in patients usually after initial therapy [65] through mechanisms including activation of antimetastatic processors and modulation of cell adhesion factors or extracellular matrix degradation components $[3,65,88]$ (Figure 1). However, interventions that interfere with all three phases will likely bring about a more meaningful degree of cancer prevention [81]. 


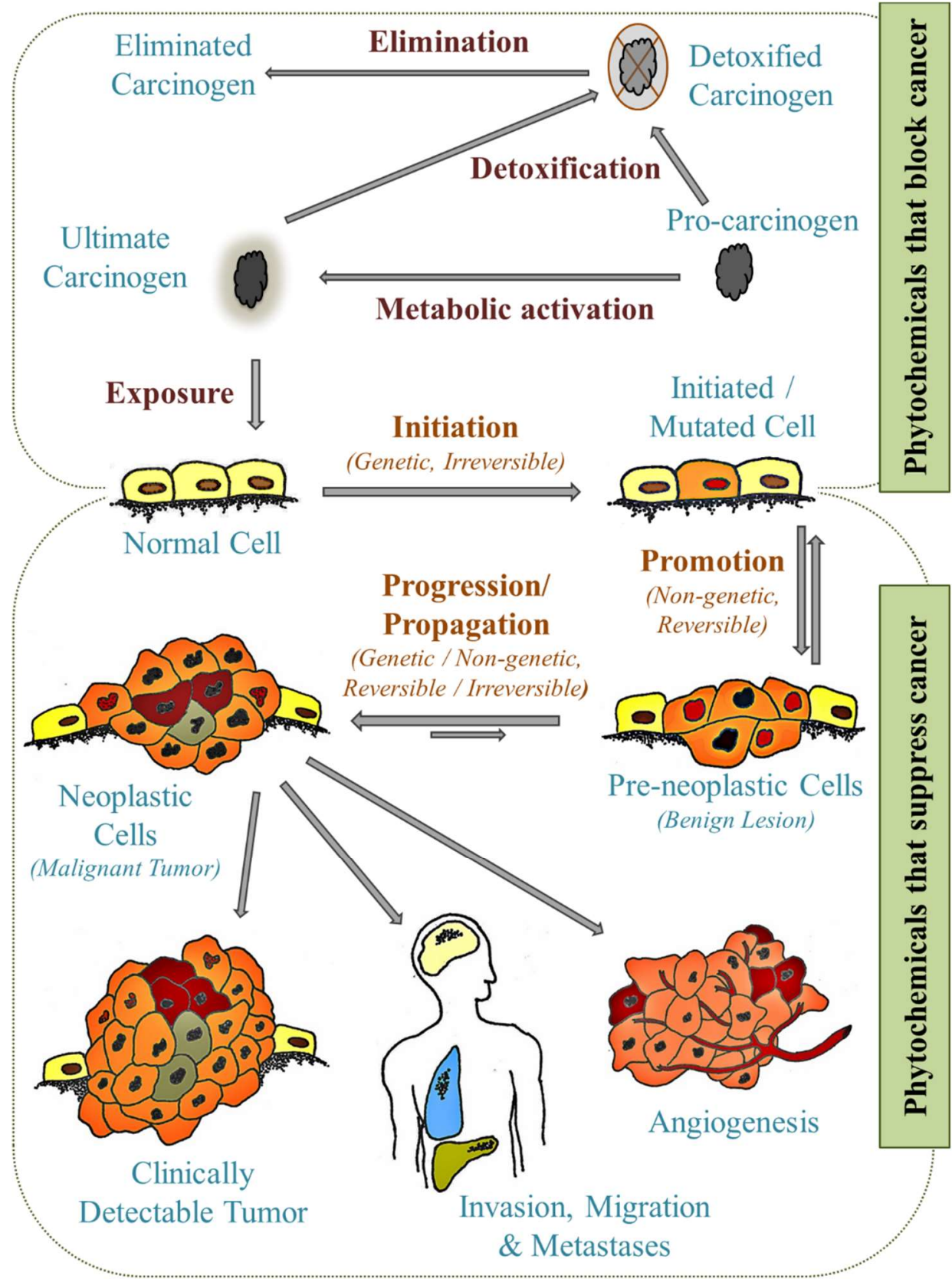

Figure 1. Polyphenolic phytochemicals (e.g., lignans) block and suppress carcinogenesis. Carcinogenesis is a multistage process of initiation, promotion, and progression. Carcinogens may initiate carcinogenesis by causing the conversion of a normal cell into an "initiated cell", a process that is irreversible and involves genetic mutations. Initiated cells further transform into pre-neoplastic cells during the stage of promotion, and subsequently progress into neoplastic cells. Polyphenolic phytochemicals are capable of interfering with cellular and molecular processors in various stages of carcinogenesis. Phytochemicals may block cancer initiation through inhibition of procarcinogen activation into electrophilic species and their subsequent interaction with DNA. Alternatively, phytochemicals can stimulate carcinogen detoxification and their subsequent elimination from the body. Phytochemicals may suppress cancer by interfering with cancer promotion (a reversible process that involves nongenetic changes) or by regulating cancer progression, a complex process that involves both genetic and nongenetic changes as well as cell survival. Some polyphenols can act as blocking agents; others act as both blocking and suppressing agents, and some function as suppressing agents to modulate autophagy, cell cycle, and differentiation, thus affecting cancer cell proliferation. Adapted from references $[3,4,67]$. 
In general, chemoprevention can be achieved through reduction in bioactivation of procarcinogens, obstruction of expansion of additional malignant cells, or through suppression of metabolism of specific compounds to reduce toxicity [4,92]. This understanding has led to four notable categories of chemoprevention and include medications, hormones (i.e., antiestrogens and antiandrogens), vaccines, and dietary agents [93]. Only a handful of agents have been clinically approved for cancer chemoprevention (e.g., the anti-inflammatory drugs, aspirin, celecoxib and diclofenac) [70,71], with several others suggested as possible chemopreventive agents (e.g., the anti-hypercholesterolemic statins, the antidiabetic drug metformin, and antiosteoporosis bisphosphonates) [94]. The complexity associated with cancer pathogenesis has otherwise limited our ability to identify primary, secondary, or tertiary interventions that effectively reduce cancer risk or progression. The cost of patient survival and quality of life, though, continue to drive research into effective chemopreventive interventions $[70,71,91,95]$.

An active avenue of research in chemoprevention involves natural chemicals derived from plants (i.e., phytochemicals). Over 80,000 species of plants are utilized in healthcare management, while more than $60 \%$ of the existing anticancer drugs come from nature [96]. The broad selection of biologically active, structurally different natural compounds continues to aid the process of cancer drug discovery with respect to chemoprevention and chemotherapy [97,98]. An abundance of phytochemical constituents with preventive anticancer properties against cancers such as lung, breast, ovarian, prostate, thyroid, and colon have been reported throughout the literature [92,99-109]. These phytochemicals have not seen wide application despite the limitations of current treatment methods [110] as general Western practices often dismiss their value for patient treatment. For this reason, researchers covering a wide area of health research have turned their focus on alternate ways to address the issues related to general western practices and to capitalize on the protective effects of phytochemicals [111].

\section{Alternate Approaches to Malignant Disease}

The Halifax Project-an international task force comprising of 180 scientists-has posed a "broad-spectrum therapeutic approach" as an alternate low-toxicity strategy to mitigate the problems of cancer chemotherapy [58]. Following from a rigorous examination of the cancer hallmarks, this interdisciplinary group identified 74 high-priority targets. Many of the suggested therapeutic approaches for these targets were phytochemicals with evidence of low toxicity [58]. Such phytochemicals are also commonly considered complementary and alternative medicines (CAMs), and are associated with integrative medicine. For cancer, integrative medicine is based on a foundation of lifestyle therapies, drawing attention to diet, dietary components, and physical activity $[58,112,113]$. It focuses on patient quality of life and demands marshalling of all therapeutic and lifestyle strategies to ensure the best outcomes and optimal health of the patient [112,114]. Phytochemicals as CAMs should be included as a strategic lifestyle intervention in a broad-spectrum approach to cancer disease management [58]. Already, the potential psychological and socioeconomic benefits of CAM use is exemplified by studies that report $32-66 \%$ of cancer patients having used cost-effective CAMs as a means to improve quality of life and therapeutic outcomes [115]. Furthermore, studies employing a combination of clinically relevant chemotherapeutic drugs with natural bioactive compounds demonstrate enhancement in antitumor effects and reduction in side-effects $[111,112,116]$. Some reports also document the potential of phytochemicals in overcoming chemoresistance and radioresistance of malignant cells [111,117]. Hence, the repositioning of traditionally considered "noncancer", nontoxic phytochemical therapies with promising antineoplastic characteristics may help achieve better therapeutic outcomes and reduced toxicity profiles [118]. Convincing practitioners of this broad-spectrum therapeutic approach will be important to ensure a larger number of patients achieve improved quality of life and cancer treatment outcomes with phytochemical interventions.

\section{Potential of Dietary Phytochemicals for Malignant Disease}

The World Health Organization (WHO) reported that approximately $65 \%$ of the world's population relied on plant-derived drugs for their primary health care by 1985 [119]. These therapies demonstrate 
potential, but their safe and rational use in Western medicine is limited by a lack of rigorous scientific investigation of their potential therapeutic and adverse effects, mechanisms of action, and interactions with pharmaceuticals and functional foods [50]. Although the use of dietary phytochemicals in cancer treatment has had a long history, their efficacy is variable due to their complexity, their poorly defined targets and modes of action, and lack of knowledge of effective doses [120]. Nonetheless, a number of phytochemicals have been applied successfully in the clinical setting such as metformin and nonsteroidal anti-inflammatory drugs (NSAIDs) [121,122]. As well, the complexity and diversity in structure of phytochemicals make these compounds an often exploited scaffold to aid the discovery and synthesis of analogs that share similar structures but with improved and modified efficacy [123-125]. High-throughput screening (HTS), a specialized tool using automation to screen compound libraries against the drug target within a short period of time [126], has made the rediscovery of phytochemicals even more feasible [55]. The pleiotropic, multitarget effects of phytochemicals as well as polypharmacology also resonate within the emerging paradigm in drug discovery [127-130]. These factors identify dietary phytochemicals as an invaluable resource for new treatment options in current unmet medical needs, such as cancer. Yet few randomized clinical trials document the use of dietary phytochemicals in combination with standard of care treatments against human malignancies. An ability of phytochemicals to enhance the efficacy of standard treatments against cancer warrants an investigation into the wide range of biologically active compounds that have been isolated, identified, and tested for their application as treatments for cancer [131].

\subsection{Dietary Polyphenols as Principal Phytochemicals for Malignant Disease}

An inverse relationship exists between the high consumption of fruits and vegetables and a reduced risk of cancer [132,133], with an average $35 \%$ of all human cancer mortality directly attributed to diet $[4,134]$. Such statistics prompted organizations such as the WHO, the American Cancer Society (ACS), the American Institute of Cancer Research (AICR), and the U.S. National Cancer Institute (NCI) to establish dietary guidelines in an attempt to reduce cancer risk [4]. These guidelines are complemented by ongoing clinical trials that investigate diet and dietary supplements for the prevention of cancer [4]. Although food is generally perceived as providing nutritional value, phytochemicals have an additional potential to modulate molecular and cellular targets [135]. Their influence on biological function suggests that institution of an adequate, economical, and rapid system for evaluation and testing of phytochemicals with potential anticancer properties may augment the current dietary guidelines or identify lead compounds for drug discovery in different cancer phenotypes [96,136].

Phytochemicals ("phyto" in Greek means plant) are bioactive non-nutritive chemical components of plant-based diets such as fruits, vegetables, nuts, and grains $[4,137]$ produced as primary and secondary metabolites of the plant [65]. These are generally classified into polyphenols, alkaloids, carotenoids, and organosulfur compounds [135,138] (Table 1). Primary metabolites are involved in plant functions such as respiration, development and photosynthesis, while secondary metabolites play a role in defense against herbivores and pathogens, attracting pollinators, and protection against ultraviolet radiation [139]. These secondary metabolites can have benefit in vertebrates as chemopreventive agents, drugs, herbicides, and antibiotics [65,139], and their chronic exposure is suggested to have health benefits for neurodegenerative disorders, cancer, diabetes and cardiovascular disease [140-142]. Polyphenols are an important class of beneficial secondary metabolites found in food and drink sources from vegetables, fruits, nuts, spices, grains, coffee tea, and wine [65].

Plant polyphenolic secondary metabolites are synthesized from carbohydrates through the shikimate pathway $[143,144]$. Although these metabolites may exist as insoluble or bound forms [144], they are present generally as glycosylated forms with single or multiple sugar or carbohydrate residues conjugated to a hydroxyl functional $(-\mathrm{OH})$ group or an aromatic ring involving a co-translational or post-translational enzymatic process. Over 8000 plant-based polyphenols have been identified [65,145], and are divided into a number of classes based on chemical structure, source, and biological function including the flavonoids (flavonols, flavones, flavanones, catechins, anthocyanidins, and isoflavones), 
phenolic acids (benzoic acids and cinnamic acids), stilbenes, lignans, coumarins, tannins, and other polyphenols (e.g., curcumin, rosmarinic acid, gingerol) $[137,139,141,146]$. More broadly, polyphenolics can be classified as either being flavonoid and nonflavonoids based on their abundance $[65,139]$. There are over 4000 types of diverse flavonoids accounting for $\sim 60 \%$ of structurally-related dietary polyphenols $[80,141]$, while $~ 30 \%$ of dietary polyphenols are phenolic acids (i.e., hydroxy-cinnamic and hydroxy-benzoic acids) $[80,141]$. Flavonoids, phenolic acids, stilbenes and lignans are the most abundantly occurring plant polyphenols [80].

Table 1. The classification of phytochemicals. Adopted from references [135,138,139].

\begin{tabular}{|c|c|c|c|c|}
\hline & Classification & & Representative Members & $\begin{array}{c}\text { Examples of Dietary } \\
\text { Sources }\end{array}$ \\
\hline \multirow{13}{*}{ Poly-Phenolics } & \multirow[t]{2}{*}{ Phenolic Acids } & $\begin{array}{l}\text { Hydroxycinnamic } \\
\text { acids }\end{array}$ & $\begin{array}{l}\text { p-Coumaric, caffeic, ferulic, } \\
\text { sinapic }\end{array}$ & $\begin{array}{c}\text { Barley, eucalyptus, coffee, } \\
\text { Arabidopsis, Hibiscus, } \\
\text { cereal grains }\end{array}$ \\
\hline & & $\begin{array}{l}\text { Hydroxybenzoic } \\
\text { acids }\end{array}$ & $\begin{array}{c}\text { Gallic, vanillic, syringic, } \\
\text { ellagic }\end{array}$ & $\begin{array}{l}\text { Chestnuts (boiled or } \\
\text { roasted), witch hazel, tea } \\
\text { leaves, oak bark, rhubarb, } \\
\text { pomegranate, grapes, } \\
\text { chocolate, wine }\end{array}$ \\
\hline & \multirow[t]{2}{*}{ Lignans } & Plant Lignans & $\begin{array}{c}\text { sesamin, secoisolariciresinol } \\
\text { diglucoside, lariciresinol, } \\
\text { isolariciresinol, } \\
\text { 7-hydroxymatairesinol, } \\
\text { matairesinol, pinoresinol, } \\
\text { arctigenin, syringaresinol, } \\
\text { asarinin }\end{array}$ & \multirow[t]{2}{*}{$\begin{array}{l}\text { Flaxseed, pumpkin, } \\
\text { sunflower, poppy, rye, } \\
\text { oats, barley, wheat, oat, } \\
\text { rye, berries }\end{array}$} \\
\hline & & $\begin{array}{c}\text { Mammalian } \\
\text { Lignans } \\
\text { (enterolignans) }\end{array}$ & Enterodiol, enterolactone & \\
\hline & Stilbenes & & & Grapes \\
\hline & Other Phenolics & Coumarins & & Tonka bean, vanilla grass \\
\hline & & Tannins & & Eucalyptus, geranium \\
\hline & \multirow{6}{*}{ Flavonoids } & Flavonols & $\begin{array}{l}\text { Quercetin, kaempferol, } \\
\text { myricetin }\end{array}$ & $\begin{array}{c}\text { Aloe Vera, European } \\
\text { elderberry, soy, St John's } \\
\text { wort, tomatoes, red onions }\end{array}$ \\
\hline & & Flavones & Apigenin, luteolin & $\begin{array}{c}\text { Celery, parsley, chamomile } \\
\text { tea, green peppers, thyme, } \\
\text { oregano }\end{array}$ \\
\hline & & $\begin{array}{l}\text { Flavanols } \\
\text { (catechins) }\end{array}$ & $\begin{array}{l}\text { Catechin, epicatechin, } \\
\text { epigallocatechin gallate }\end{array}$ & $\begin{array}{l}\text { White tea, green tea, } \\
\text { persimmon, pomegranate, } \\
\text { cocoa beans }\end{array}$ \\
\hline & & Flavanones & Eriodictyol, hesperetin & $\begin{array}{l}\text { Citrus fruits, rose hip, } \\
\text { mountain balm }\end{array}$ \\
\hline & & Anthocyanidins & $\begin{array}{c}\text { Cyanidin, pelargonidin, } \\
\text { malvidin }\end{array}$ & $\begin{array}{l}\text { Grapes, berries, red } \\
\text { cabbage, red onions, } \\
\text { plums, kidney beans, } \\
\text { geranium }\end{array}$ \\
\hline & & Isoflavonoids & Genistein, glycitein & $\begin{array}{l}\text { Lupin, fava beans, soy, } \\
\text { coffee }\end{array}$ \\
\hline Alkaloids & & & & Poppy, tomatoes, potatoes \\
\hline Carotenoids & $\begin{array}{c}\alpha \text {-carotene, } \\
\beta \text {-carotene, lutein, } \\
\text { zeaxanthin, } \\
\text { lycopene }\end{array}$ & & & $\begin{array}{l}\text { Carrots, broccoli, spinach, } \\
\text { zucchini }\end{array}$ \\
\hline $\begin{array}{l}\text { Organosulfur } \\
\text { compounds }\end{array}$ & $\begin{array}{l}\text { Isothiocyanates, } \\
\text { indoles, allyl } \\
\text { sulfur compounds }\end{array}$ & & & $\begin{array}{l}\text { Cabbage, broccoli, spinach, } \\
\text { garlic, onions }\end{array}$ \\
\hline
\end{tabular}


The literature provides ample evidence for the anticancer properties of polyphenols [2,140,147-150]. The key anticancer characteristics of polyphenols include anti-inflammatory and antioxidative effects, immunomodulation, and modulation of molecular/cellular targets within signaling pathways involved with cell proliferation, survival, differentiation, angiogenesis, migration, and hormonal activities [2,151,152]. In general, the pleiotropic effects of dietary polyphenols usually follow from their multitarget effects having the ability to impact an entire process or several processors of the malignant disease condition or status. Polyphenols typically exhibit low to moderate affinity for their targets. However, their ability to simultaneously modulate multiple targets with low affinity is suggested to account for their effects in the cancer phenotype $[153,154]$. Since bioactivity is not only dependent upon the interaction of the polyphenol with its target sites, but also on the chronic exposure to the polyphenol, the increasing popularity of polyphenols have led to the emergence of two new terms, 'nutridynamics' and 'nutrikinetics' $[155,156]$. These terms, similar in meaning to drug pharmacodynamics and pharmacokinetics, are expected to make significant contributions in our understanding of the relationship between disease phenotypes and bioactivity, as well as the interplay between chronic exposure and the host's physiology including digestion, metabolism, and gastrointestinal microflora $[157,158]$.

\subsection{General Properties of Polyphenols and Evidence on Health}

As drug discovery efforts continue to move away from single target drugs, the multitarget characteristics of polyphenols, such as the lignans, warrant further attention to fully grasp their potential use in the clinic. Diet-derived polyphenols have gained popularity among nutritionists, food scientists, and consumers during recent years for their health-promoting and chemopreventive properties [141,159]. The beneficial effects on human health by long-term polyphenol rich diet consumption is linked to the modulation of cell proliferation, body weight, chronic disease, and metabolism [160]. The antioxidant and anti-inflammatory potential of polyphenols as indicated in animal, human, and epidemiologic studies, suggest chemopreventive or therapeutic effects for a number of noncommunicable diseases such as neurodegenerative disorders, obesity, diabetes, cardiovascular disease, osteoporosis, gastrointestinal issues, pancreatitis, and cancer [160-162]. Overconsumption of dietary polyphenols, especially when they are not consumed in a form of a food matrix, though, may result in adverse effects on health $[160,163,164]$. Our understanding of the mechanisms underlying the potential health benefits largely arise from in vitro studies and, therefore, a certain degree of uncertainty exists if these mechanisms hold true in human patients [160,165-168]. Nonetheless, polyphenol mechanism of action has greater complexity than the long standing belief that polyphenols form stabilized chemical complexes to negate free radicals and prevent further reactions [160,169], or result in the production of hydrogen peroxide $\left(\mathrm{H}_{2} \mathrm{O}_{2}\right)$ for protection against oxidative stress to aid in the immune response and modulate cell growth $[160,169,170]$.

\subsubsection{General Pharmacodynamic (or Nutridynamic) Effects of Polyphenols}

In general, nutridynamic effects of polyphenols can be broadly summarized and grouped based on the following general molecular mechanisms [92]; (a) modulation of phase I and II drug metabolizing enzymes (e.g., cytochrome P450s and UDP-glucuronyltransferases) [69,80,141,171-173]; (b) inhibition of reactive oxygen species and modulation of antioxidant activity $[4,141,171,174-176]$; (c) inhibition of multidrug resistance (e.g., c-Myc and HDACs) [4,80,141,176,177]; (d) modulation of inflammation [69,141,172,175,177]; (e) modulation of androgen and estrogenic activity [141,176,178-181]; (f) inhibition of tyrosine kinases [80,141,176,177,182]; (g) modulation of matrix metalloproteinases, epithelial-to-mesenchymal transition [183], and metastases [80,91,141,172,177]; (h) modulation of angiogenesis [91,141,171,177,184]; (i) inhibition of cell cycle regulators and induction of cell cycle arrest $[80,141,171,177,185]$; (j) induction of apoptosis [80,91,141,171,175]; (k) inhibition of cell growth and proliferation [91,141,174,175,177]; (1) modulation of endoplasmic reticulum-stress and type II programmed cell death or autophagy [141,175,176,185-187]; (m) modulation of mitogen-activated protein 
kinases [69,141,171,176,177]; (n) modulation of PI3K-AKT signaling [4,69,141,177,185]; (o) modulation of JNK pathway [80,141,176,177,185]; (p) modulation of glucose and lipid [69,171,174,185,188,189]; and (q) hepatoprotective effects [190-194]. However, only a few polyphenols (e.g., flavonoids) have gained approval as NHPs, some with defined health claims, and none have been widely approved for clinical use [92].

\subsubsection{General Pharmacokinetic (Or Nutrikinetic) Characteristics of Polyphenols}

Absorption and disposition (i.e., nutrikinetics) characteristics play an important role in exposure to dietary polyphenols and their eventual therapeutic effects. With oral consumption, nutrikinetic processes ultimately determine the concentration and persistence of polyphenolic compounds at their target sites. Since both genetic and epigenetic factors influence the nutrikinetics of polyphenols, these factors often result in considerable interindividual variation in blood and tissue exposure levels $[137,195-200]$. Despite the importance of nutrikinetics as a determinant of polyphenolic action, only a handful of in vivo studies have systematically addressed the factors that contribute to the differences in their absorption and disposition characteristics [137].

Dietary polyphenols must become systemically available to influence cancer treatment. Many plant polyphenols first undergo modification by gastrointestinal enzymes and/or bacteria to produce metabolites that are more or less systemically biologically active. The initial metabolic transformations typically involve deglycosylation to release aglycones into the gastrointestinal tract lumen following enzymatic breakdown of polymeric forms with subsequent deconjugation of monomeric forms by $\beta$-glucosidases on the brush border membrane or by the resident (small intestine and colon) gut bacteria $[137,143,144]$. These aglycones may undergo absorption or be further subjected to microbial enzymatic transformations including ring fission, $\alpha / \beta$-oxidation, dihydroxylation, dehydrogenation, and demethylation reactions [137,144,201-203], with their subsequent absorption from the gastrointestinal lumen. Given their interactions with intestinal bacteria, polyphenols also can induce intestinal microbial changes [144], with reports that identify a polyphenol-gut microbiota interaction that either contributes to or prevents the development of disease [144,204,205].

During their permeation across the intestinal epithelium or with passage through the liver, aglycones or their metabolites may undergo extensive first-pass metabolism. These metabolic transformations typically involve conjugation reactions, with glucuronic acid or, to a lesser extent, with glutathione or sulfate [137]. UDP-glucuronosyltransferases (UGT), sulfotransferases (SULTs), and glutathione-S-transferases (GST) carry out conjugation reactions in both enterocytes and hepatocytes to produce conjugates that are excreted into the bile or become systemically available with subsequent excretion by the kidney into the urine [137]. Conjugates excreted into bile may undergo enterohepatic recycling making available the nonconjugated form for absorption following deconjugation by intestinal and/or microbial $\beta$-glucuronidase [137]. Typically, the aglycones are more biologically active, but the glycosidic forms, and rarely the glucuronide conjugates, have biological activity [137,206-213].

An important consideration in the oral bioavailability of phytochemicals is the role of intestinal epithelial transporters. Plasma membrane ATP-binding cassette (ABC) transporters play a vital role in the systemic availability of a number of dietary polyphenols or their metabolites. These ATP-dependent transmembrane efflux transporters are expressed on the apical or basolateral epithelial membrane, depending on the isoform. On the basolateral membrane, ABC transporters actively efflux phytochemical conjugates from intestinal cells (where conjugation occurred) into the portal blood supply. When expressed on the apical side of the epithelium, ABC transporters efflux phytochemicals back into the intestinal lumen to cause reductions in oral bioavailability [137]. P-Glycoprotein (Pgp/ABCB1/MDR1), multidrug resistance proteins (MRPs/ABCCs), and the breast cancer resistance protein (BCRP/ABCG2) are the key ABC efflux transporters $[137,214,215]$ known to influence systemic availability of a number of dietary polyphenols $[216,217]$. For example, enterolactone is a substrate and competitive inhibitor of ABCG2 [218]. These ABC transporters exhibit several genetic polymorphisms 
that may influence the systemic availability of these compounds, which can contribute to considerable interindividual variation in their oral bioavailability [219-221].

Members of the solute carrier (SLC) family of transporters also contribute to the intestinal epithelial uptake of certain dietary polyphenolic compounds. The polar glycosidic forms of the dietary polyphenols typically exploit SLC transporters to ensure their systemic availability [142,222-225]. Glucosides could be transported into enterocytes by sodium-dependent glucose transporters (SGLT) such as SGLT-1 [142]. Once inside they can be hydrolyzed by cytosolic $\beta$-glucosidase to their aglycone forms [142]. Additionally, in the small intestine brush border membrane, extracellular hydrolysis of several glucosides can be carried out by lactase phloridzine hydrolase [142]. Although it is speculated that both enzymes are involved this process, their relative contribution towards different glucosides is unknown [142]. The aglycone metabolites have sufficient lipophilicity for passive diffusion to be the principal transport process during absorption. However, some polyphenols show ability to inhibit SLC transporters to influence the uptake of substrates of such transporters [215].

The relatively limited information on the tissue distribution of dietary polyphenols largely comes from preclinical evaluations with rodent models. Polyphenol compounds generally accumulate in highly perfused tissues such as the liver, kidney, heart, lung, and intestine, and many are present predominantly in their conjugated forms [142,145,226-231]. Tissue specific accumulation is observed as well, as is the case for flaxseed lignans which accumulate in prostate and breast tissue [232,233]. Extent of plasma protein binding, which can function to limit availability of polyphenols to tissue sites depending upon relative affinity between plasma protein and tissue binding sites, tends to increase with increasing lipophilicity of the compounds [213,230,234-237]. However, the polar conjugates of dietary polyphenols exhibit very limited plasma protein binding characteristics. Finally, expression of ABC transporters at tissue-blood barriers might limit access of certain polyphenols to such tissues preventing their accumulation and possible activity at such sites. For example, tumor cells typically overexpress $A B C$ transporters to restrict access of a broad range of chemically unrelated pharmacological therapeutics to the cancer cell (aka multidrug resistance or MDR) [215]. ABC transporters also function to reduce intracellular concentrations of polyphenols, but as competitive inhibitors [215] polyphenols may enhance the cellular concentration and pharmacological response of chemotherapeutic drugs [238-240].

Most polyphenols are eliminated by intestinal and hepatic metabolism [241,242]. Aglycones of plant polyphenols that bypass first-pass metabolism are typically eliminated via hepatic phase II metabolism with the subsequent excretion of these metabolites by the biliary or renal system [241-243]. First-pass and systemic phase II metabolism are typically considered inactivation processes that result in loss of biological activity [241]. Very limited phase I metabolism occurs yielding primarily aromatic hydroxylated metabolites largely mediated by the cytochrome P450 enzyme superfamily [241,244,245]. These hydroxylated metabolites undergo further phase II conjugation and subsequent excretion by the kidney [241,242]. Given the extensive first-pass metabolism and ability to undergo enterohepatic recirculation, fecal excretion represents a major route of elimination of many dietary polyphenols, while fecal and urinary excretion is the principal route of elimination for the metabolites of polyphenols [231,241,246].

\section{Challenges Associated with Cancer Prevention and Dietary Polyphenols}

Screening, early detection, and chemoprevention are widely accepted as the major strategies to address the burden of cancer [85]. Chemoprevention as a major strategy is viewed less optimistically, as there exists a lack of clear understanding of the benefits of chemoprevention. The clustering of various approaches including dietary manipulation, NHPs such as polyphenols, and repurposed "benign drugs" into the idea of chemoprevention has done little to mitigate the uncertainty associated with the value of chemoprevention in reducing cancer risks [85]. Nonetheless, preventive strategies support the rationale for the early disruption of the carcinogenic process, which can avoid the treatment difficulties arising with the complexity and heterogeneity of more advanced stage cancers [85]. Chemoprevention has potential to address the many intrinsic genetic, epigenetic, and environmental factors that influence individual risk for cancer [85,247-252]. Hence, a basic rethinking of the nature of carcinogenesis 
as proceeding in a nonlinear fashion with irregular interruptions owing to changes in genetics and epigenetics [85] may benefit and expand the understanding and application of chemoprevention [85].

A variety of obstacles have hindered the development of dietary polyphenols as clinically approved chemopreventives. There has been a general inability to confirm their effect in reducing cancer risk due to a number of factors that include the lack of appropriate experimental models, the costs and time associated with epidemiological studies, as well as variations in length of exposure and adherence data in clinical populations, difficulties in evaluating the dietary intake of polyphenols, the variation in composition of polyphenols among different dietary sources, degradation or alteration of polyphenol chemical structures that may result in loss of bioactivity, variability and unpredictability in pharmacokinetic profiles, the impact of the microbiome on polyphenol bioactivity, and drug-polyphenol interactions [92,160,230,253-260]. To address these obstacles, research is focusing on improved extraction and purification methodology [92,261-264], development of microbial production systems for plant polyphenols [265-270], formulation of polyphenols into micro- or nanodelivery systems [271-274], development of antibody directed enzyme prodrug therapy approaches [275-278], administration of glycosidic derivatives [92,279,280], use of bioenhancers [281-283] or specific ATP binding cassette transporter inhibitors [92,284], use of antibiotics or other natural products to modulate intestinal microflora [260,285], development of novel polyphenol derivatives by modification of chemical structures [286-290], and polyphenol complexing with protein or phospholipids [92,291-295]. To date though, much of the investigation into polyphenols have involved in vitro evaluations and a sparsity of clinical trials using well-defined amounts of polyphenolic compounds [296] suggests a need for well-conducted clinical investigations to resolve their safety and efficacy as chemopreventives. The substantive evidence that exist beyond their publicized antioxidant properties [259,297], for their selective actions on a plethora of cellular and molecular signaling pathways, warrant their investigation in human clinical populations so that we may realize the health benefits of polyphenols in chronic diseases such as cancer [298-301].

\section{Polyphenols of Flaxseed as Important Phytochemicals in Malignant Disease}

Flax is well known for its usefulness as a source for industrial oil and fiber [109,302]. Canada and the United States are among the top producers of flax [15]. Flaxseed is considered to be a multicomponent system consisting of plant-based dietary fiber (insoluble $20-30 \%$ and soluble fiber $9-10 \%$ ), oil (triacylglyceride fatty acid typically include linolenic $52 \%$, linoleic $17 \%$, oleic $20 \%$, palmitic $6 \%$, and stearic $4 \%$ acids), minor lipids and lipid-soluble components (tocopherols, monoacylglycerides, diacylglycerides, sterols, sterol-esters, phospholipids, waxes, free fatty acids, and carotenoids), protein, soluble polysaccharides, vitamins, minerals, lignans, and other phenolic compounds $[15,303,304]$. Various flaxseed products, such as whole and ground flaxseed, defatted flaxseed meal, and flaxseed oil, are available with suggested health benefits [305-314] and even health claims [308,315-318]. Although these products contain a number of bioactive substances including $\alpha$-linolenic acid and the linusorbs (cyclolinopeptides) [5,319-321], lignans receive increasing attention for their health effects [322].

The lignans of flaxseed were once marketed in a highly concentrated standardized formulation as BeneFlax ${ }^{\circledR}$, a $\sim 38 \%$ secoisolariciresinol diglucoside (SDG)-enriched product (Archer Daniel's Midland) approved by both the U.S. Food and Drug Administration Agency and Health Canada that ensured a significant source of lignan with oral consumption [323]. BeneFlax ${ }^{\circledR}$ demonstrated good tolerability and safety with long-term supplementation [323,324]. Additionally, Goyal et al. exhaustively listed the traditional and medicinal uses of different flax forms such as flaxseed tea, flaxseed flour and flaxseed drink for various health conditions as well as of various medicinal preparations using flaxseed oil [15]. Flaxseed oil, whole seed, ground whole seed, fully defatted flaxseed meal, partially defatted flaxseed meal, flaxseed hulls, flaxseed mucilage extracts, flaxseed oleosomes, and flaxseed alcohol extracts are among the many different types of available flaxseed products for consumption [304]. However, most of these commercially available products contain insufficient amounts of lignan, with levels of consumption unlikely to achieve therapeutic concentrations. The use of such products containing 
relatively modest to low lignan levels in studies investigating the health effects of lignans have contributed to inconclusive and unsatisfactory results of flaxseed lignan interventions [325-329]. The mounting preclinical and clinical evidence, though, suggests a need to revisit the requirement for lignan enriched products, particularly as the role of flaxseed lignans against chronic disease such as cancer continues to attract increased attention [22,33,303,330-347]. These include detailed investigations into the molecular mechanisms in order to relate to lignan safety and efficacy in malignant disease.

\subsection{Lignans of Flaxseed}

Naturally occurring plant lignans are present in vegetables, fruits, and whole grains [22], although the major source is flaxseed (the richest known source with 9-30 mg per gram, with lignan production at 75-800 times over other sources [28,348]) followed by sesame and rye bran [349]. The seed of Linum usitatissimum (Linum, a Celtic word for lin or "thread," and usitatissimum, a Latin word for "most useful" [302]) contains a rich source of the plant lignan, secoisolariciresinol diglucoside (SDG) [350], and contains minor amounts of other lignans [351,352] and cyanide-containing substances $[213,303,353]$. Biosynthesis of lignans in flaxseed is reported to occur through the following pathways that include phenylpropanoid pathway, stereospecific coupling by dirigent proteins, biosynthesis of dibenzylbutane lignans, and glycosylation of lignans into SDG [6,354-356]. SDG primarily exists in the seed hulls [350] with an average of $32 \mathrm{nmol} / \mathrm{mg}$ hull compared with $9.2 \mathrm{nmol} / \mathrm{mg}$ in the other parts of the seed [357]. Flax is an old agronomic crop with over 300 species [318]. Newer cultivars, though, can contain higher concentrations of lignans in the hull [358,359]. Differences in climatic conditions and methods of cultivation can influence the percentage composition of the various bioactive compounds [213,360,361]. In 1956, Bakke and Klosterman were first to isolate SDG from flaxseed [213]. However, scientific interest grew in the early 1970s with the discovery of enterodiol and enterolactone, later referred to as the mammalian lignans [362,363] when Axelson et al. identified SDG as the precursor for mammalian lignans $[213,364]$. Traditionally, plant lignans are considered phytoestrogens along with stilbenes and flavonoids containing the dibenzyl butane scaffold [213,365,366]. Today, lignan interest as potential bioactive compounds goes beyond the long-held belief of estrogenic effects as their health benefits undergo further scrutiny at the molecular level.

\subsection{Chemistry and Pharmacokinetics (or Nutrikinetics) of Lignans}

Lignans are a complex class of polyphenolic bioactive phytochemicals. Lignans can be described as stereospecific dimers of monolignols (aka cinnamic alcohols) bonded at carbon 8, which can exist free or bound to sugars in plants [39]. Secoisolariciresinol, syringaresinol, and pinoresinol are commonly found lignan diglucosides [39]. The major lignan, SDG, exists as two enantiomers-(+) and (-)-with varying distribution in different Linum species where some species predominatly contain one of the two enantiomers, while others contain both (e.g., L. elegans and L. flavum) [6,302]. Additionally, hydroxycinnamic acid derived monolignols can be dimerized into lignans (monolignol dimers) or polymerized into lignins (insoluble dietary fibers composed of p-coumaryl, coniferyl, and sinapyl hydroxycinnamic alcohol large polymers [367,368]) [39]. Although lignans are not categorized as dietary fibers, lignans and lignins share some chemical characteristics [39,369]. Mataresinol (MAT), SDG, lariciresinol, and pinoresinol are the most common plant lignans, but the lignans arctigenin, syringaresinol, cyclolariciresinol (isolariciresinol), medioresinol, $7^{\prime}$-hydroxymatairesinol, and 7-hydroxysecoisolariciresinol, sesamin, and the lignan precursor sesamolin, can also exist in plant-based food $[39,138,370]$.

Flaxseed lignans are formed by the coupling of two coniferyl alcohol residues that become integrated into an oligomeric polymeric structure, termed the lignan macromolecule $[371,373,374]$ (Figure S1). This polymer complex is composed of five SDG structures held together by four hydroxy-methylglutaric acid (HMGA) residues (3-hydroxy-3-methyl glutaric acid [371]) with the hydroxycinnamic acids, $\mathrm{p}$-coumaric glucoside $(4-\mathrm{O}-\beta-\mathrm{d}$-glucopyranosyl-p-coumaric acid or linocinnamarin [371]), and ferulic acid glucoside (4-O- $\beta$-d-glucopyranosyl ferulic acid [371]) as 
end units linked to the glucosyl moiety of SDG [354,372,374-376]. HMGA is considered the backbone of the lignan macromolecule [374] (Figure 2). The flavonoid herbacetin diglucoside (HDG) is also part of the lignan macromolecule attached via ester linkages with HMGA, similar to SDG [374,377]. This complex is a straight chain oligomeric complex with an average molecular weight of $4000 \mathrm{Da}$ [371] and the average chain length of the complex is three SDG moieties with a hydroxycinnamic acid at each of the terminal positions [372]. Additionally, caffeic acid glucoside (CaAG) has also been isolated from the flaxseed lignan macromolecule [378]. The suggestion that the different phenolic compounds of flaxseed exist in acylated forms adds further complexity to the lignan polymer composition of flaxseed [371].

(a)

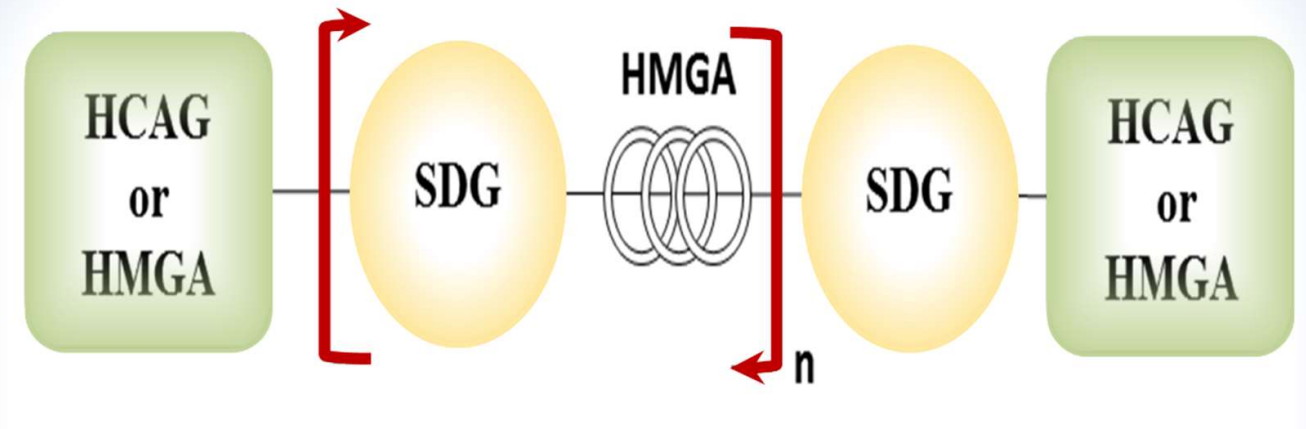

(b)

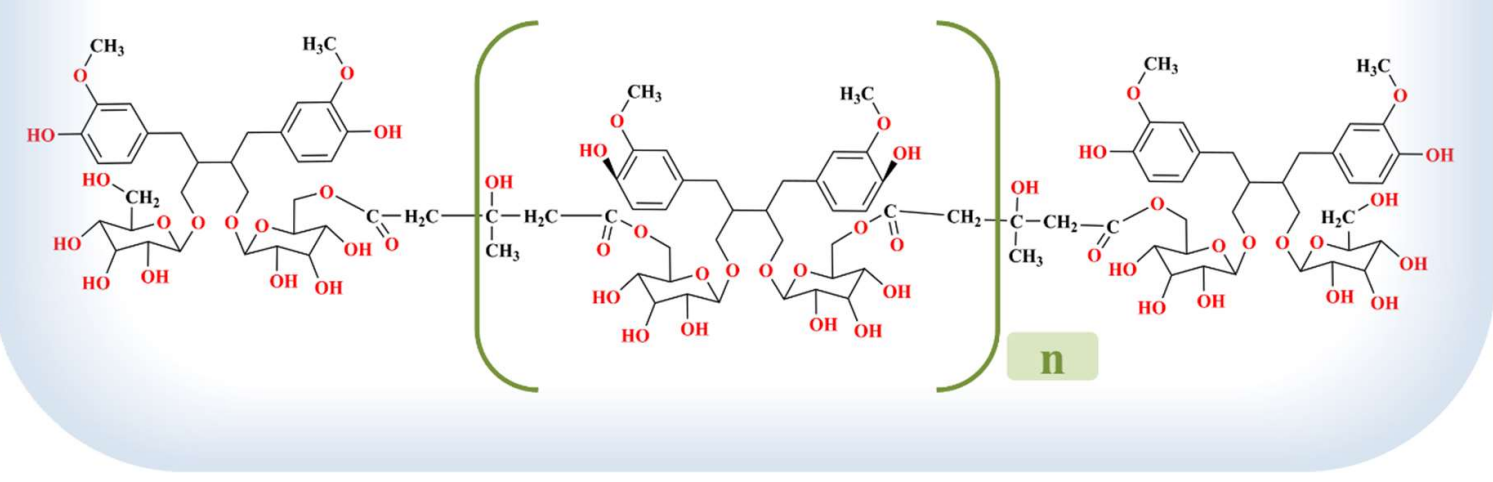

Figure 2. Chemical composition of flaxseed. (a) Schematic representation of the lignan macromolecule. The principal flaxseed lignan, secoisolariciresinol diglucoside (SDG), exists as a macromolecule in the flaxseed hull. This polymer complex is composed of five SDG structures held together by four hydroxy-methylglutaric acid (HMGA) residues with the hydroxycinnamic acids, p-coumaric glucoside (4-O- $\beta$-d-glucopyranosyl-p-coumaric acid or linocinnamarin) (CouAG), and ferulic acid glucoside (4-O- $\beta$-d-glucopyranosyl ferulic acid) (FeAG) as end units linked to the glucosyl moiety of SDG. The backbone moieties of this macromolecule are represented by the circles. The overlapping circles represent the linker molecule HMGA and the squares represent the terminal units. The terminal unit can be CouAG/FeAG or HMGA. (b) Postulated structure of the lignan oligomer. The SDG-HMGA polymer complex is converted into its monomer units-3-HMGA and SDG-by hydrolysis (average size, $n$ =3). Flaxseed contains high levels of the lignan oligomer (with ester linkages to HMGA, cinnamic acid, and other phenolic glucosides), which undergoes conversion to its aglycone, secoisolariciresinol (SECO), with further biotransformation into mammalian lignans by the action of the colonic bacteria in mammalian systems. Adopted from references [234,302,348,371,372].

The bioactivity of the lignans requires their removal from the oligomeric macromolecule structure upon oral consumption of the seed hull. The mechanism of release of SDG from the complex is 
uncertain, but the cleavage of the glucose groups of SDG is thought to be mediated by $\beta$-glucosidase and bacterial fermentation in the gastrointestinal tract to yield its aglycone, secoisolarisiresinol (SECO) [379]. SDG-deglycosolating bacteria strains Clostridium sp. SDG-Mt85-3Db (DQ100445), Bacteroides ovatus SDG-Mt85-3Cy (DQ100446), Bacteroides fragilis SDG-Mt85-4C (DQ100447), and B. fragilis SDG-Mt85-5B (DQ100448) are mainly responsible for conversion in the human gastrointestinal tract $[55,380]$. Alternative bacterial species (e.g., Butyrivibrio fibrosolvens, Peptostreptococcus anaerobius, and Fibrobacter succinogens in cow [381] and Klebsiella [382], Bacteroides distasonis, Clostridium cocleatum, Butyribacterium methylotrophicum, Eubacterium callendari, Eubacterium limosum, Ruminococcus productus, Peptostreptococcus productus, Clostridium scindens, Eggerthella lenta and ED-Mt61/PYG-s6 in human [179,380,383,384] and Ruminococcus gnavus in goat [385], Prevotella spp., and B. proteoclasticus [381]) are also involved in various reactions with lignan conversion [380,381]. SECO may undergo further bacterial demethylation and dihydroxylation reactions to produce the mammalian lignan, enterodiol (ED), which undergoes further oxidation to enterolactone (ENL) by microbes. Streptomyces avermitilis MA-4680 and Nocardia farcinica IFM10152 bacteria have the highest hydroxylation activity for ED [386]. The microorganism P450 enzyme, Nfa45180, is reported to show the highest hydroxylation activity towards ED, especially for ortho-hydroxylation of the aromatic ring in vivo [386]. Other plant lignans in flaxseed, such as matairesinol (MAT), pinoresinol (pinoresinol diglucoside [387]), and lariciresinol (isolariciresinol [351]) that are found in minor amounts, are also converted into the mammalian lignans ENL and ED [46,388] (Figure 3). Hence, following consumption, SDG is released from the macromolecule (the exact location within the gastrointestinal tract is unknown) and is principally converted to the mammalian lignans in the lower intestine, either by the brush border enzymatic activity of the gut mucosa or by bacterial enzymatic activity [379,389]. Oral antimicrobial drugs are known to decrease serum concentrations of mammalian lignans highlighting the importance of gastrointestinal flora in the production of mammalian lignan [390]. A detailed composition of the flax lignan macromolecule, history of lignans and the analytical methods used to identify lignans as well as extraction, isolation and purification techniques are described in previous reviews [28,391].

Bioactivity of the lignans also requires their adequate systemic exposure following oral consumption. Systemic exposure of the lignans is generally quite low due to their limited oral bioavailability. As a polar molecule, SDG does not undergo oral absorption due to its poor permeation characteristics across the gastrointestinal mucosa [199,213,234,323,392,393]. The lipophilicity of the aglycone SECO and the mammalian lignans encourages passive diffusion across the gastrointestinal mucosa [392]. However, these lignan metabolites (Table S1) are subject to extensive first-pass metabolism, primarily through phase II conjugation reactions, before they enter the systemic circulation resulting in their rather limited bioavailability [55,323,379,392-399]. Glucuronidation by UDG-glucuronosyltransferases (UGTs) is the principal conjugative reaction, although sulfation by sulfotransferases (STs) and, to a minor extent, methylation by catechol-O-methyltransferase also contribute to lignan metabolite metabolism [246]. Although the ST isoforms involved in lignan metabolism are unknown, animal studies suggest the UGT2B subfamily is principally responsible for the glucuronidation of lignans to mono- and diglucuronic acid conjugates [55,400]. The extent of conjugation relates to the order of lipophilicity (SDG $<$ SECO $<$ ED $<$ ENL) [392], and therefore indicates that metabolism, excretion, and the ratios of each conjugate and aglycone may vary depending upon the cell and tissue type. Polar conjugates of the lignans produced in enterocytes are transported out of the cell to the portal blood supply through the activity of the multidrug resistance-like protein, MRP3 [242]. Such polar metabolites bypass the liver and are ultimately excreted by the kidney, but lignans escaping intestinal first-pass metabolism undergo additional hepatic phase II metabolism and to a limited extent, cytochrome P450 enzyme mediated metabolism [46,55,213]. Relevant lignan-drug interactions have not been identified, but lignans may reversibly inhibit several cytochrome P450 enzymes at high concentrations [213,401]. Additionally, SECO and ENL can activate the nuclear receptor pregnane $X$ receptor (PXR), which may modulate the induction of phase I and II enzymes and, in turn, alter systemic and tissue concentrations of other substrates of these enzymes [213,402]. 


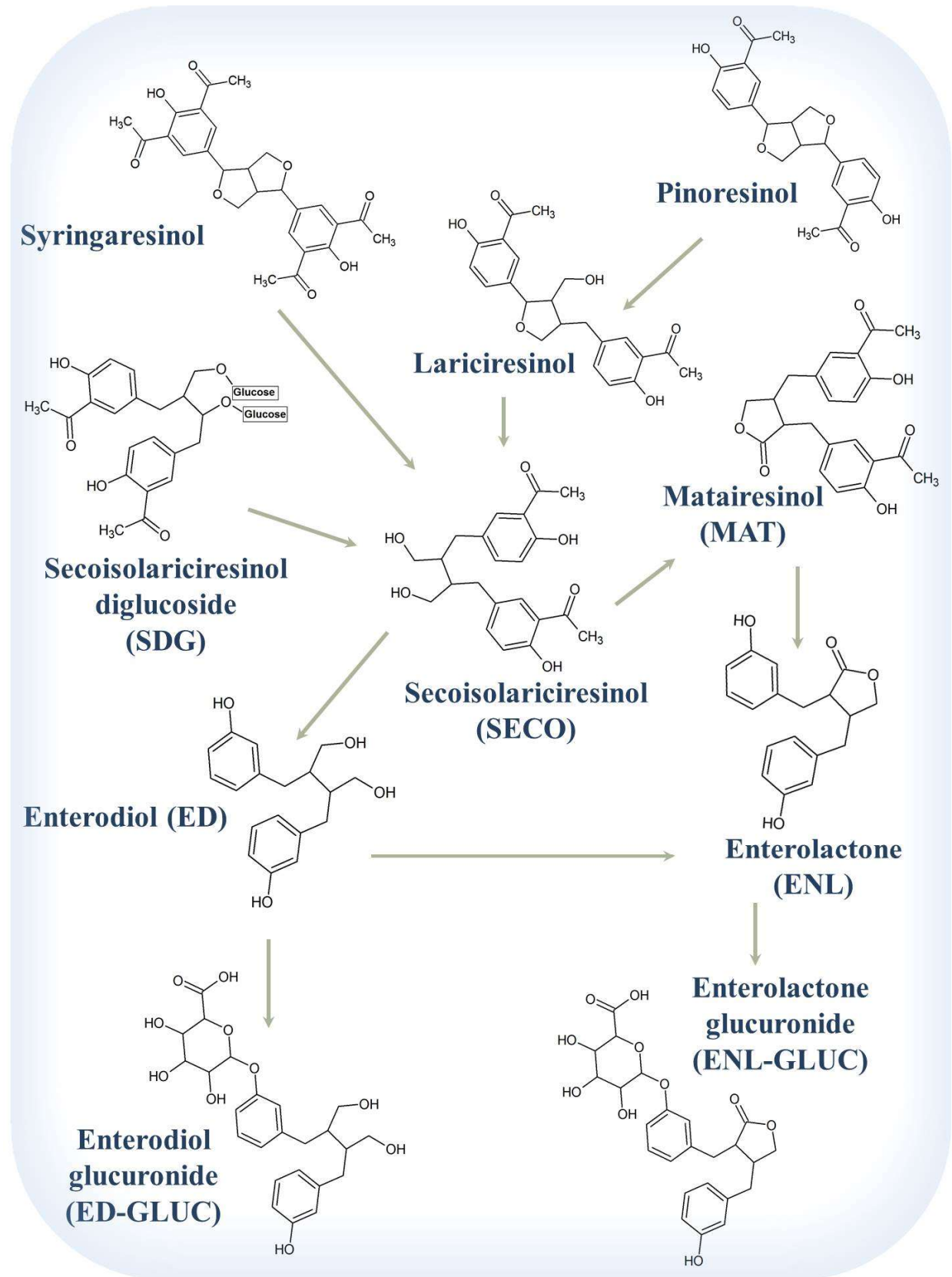

Figure 3. Lignan chemical structure and metabolites. Plant lignans are converted to various metabolites including the mammalian lignans (enterolactone (ENL) and enteroldiol (ED)) and their phase II metabolites such as glucuronide conjugates. The conversion of plant lignan secoisolariciresinol diglucoside (SDG) into the mammalian lignans can by separated into four catalytic reactions in order of O-deglycosylation (SDG to the its aglycone, SECO), O-demethylation (SECO to 2,3-bis (3'-hydroxybenzyl)butyrolactone/2,3-bis(3,4-dihydroxybenzyl)butane-1,4-diol), dehydrogenation (2,3-bis(3,4-dihydroxybenzyl)butane-1,4-diol to ED), and dihydroxylation (ED to ENL). Adopted from references [42,380,381,384].

Given the propensity for hepatic phase II metabolism, SECO, ED, and ENL undergo enterohepatic recirculation [403] (Figure 4). Reabsorption of nonconjugated lignans result in fluctuations in plasma concentrations, as evidenced by secondary peaks in the oral plasma concentration-time profile [213], and prolongation of their mean residence times in the body $[199,213]$. Approximately $20-50 \%$ of glucuronide and sulphate conjugates are excreted into the bile $[213,404]$, and of this amount $80 \%$ is deconjugated by $\beta$-glucuronidase of intestinal microflora in the intestinal lumen $[213,405]$. $\beta$-glucuronidase activity 
has been detected in various bacterial genera such as Bacteroides, Bifidobacterium, Eubacterium, and Ruminococcus, belonging to the prominent human intestinal microbiota [406], and specifically genes encoding $\beta$-glucuronidase have been described in Escherichia coli, Lactobacillus gasseri, Clostridium perfringens, Staphylococcus aureus, and Thermotoga maritina [406]. Due to the high $\beta$-glucuronidase activity, such glucuronides are more likely to be hydrolyzed back to their aglycone forms for reabsorption or their fecal excretion. As a result, physiologically relevant lignan concentrations in the range of 10 to $1000 \mu \mathrm{M}$ are likely achievable in the colon lumen [407,408]. Enterohepatic recirculation also results in $10-35 \%$ of conjugated and unconjugated lignan excretion by the fecal route [213,409-412]. However, a considerable proportion is excreted by the kidney as glucuronide conjugates with permanent removal from the body [213,413]. Generally, a good correlation exists between plasma concentrations and urinary excretion of various lignan metabolites $[213,411,414]$, but the relative ratio and extent of urinary excretion can vary depending upon population characteristics, e.g., postmenopausal women with or without breast cancer [199,213,415-417]. Additionally, small portions of enterolignans have been reported to be found in certain animal based food such as milk [39,418-420] and therefore can be considered as another route of excretion.

Blood and tissue levels of the lignans and their conjugative metabolites show a high degree of interindividual variability due to variation in their absorption and disposition (distribution and elimination) characteristics as well as differences in diet, microflora, gender, and age [213,421]. Extensive first-pass metabolism results in concentrations of unconjugated SECO, ED, and ENL in the lower nanomolar range [323,421-424], with concentration of the conjugated forms 250 times or more higher than the unconjugated lignans $[55,213,323,379,393]$. Low plasma concentrations are also due to their wide distribution throughout the body with detection in tissues such as the intestine, liver, lung, kidney, breast, heart, and brain with higher levels in liver and kidney [213,232,392,404,425,426]. In humans, plasma protein binding of flaxseed lignans is unknown but in rat plasma the unbound fraction for SECO, ED, and ENL was 33\%, 7\%, and 2\%, respectively [234]. Plasma protein binding of the conjugated metabolites of SECO, ED, and ENL is likely very low given the polar nature of these metabolites. Additionally, an erythrocyte partitioning study indicated no accumulation of ENL in erythrocytes [234]. Despite low blood levels of ENL and the polar nature of the conjugates, ENL and its conjugates seem to concentrate in body fluids such as breast milk, intestinal fluid, prostatic and breast cyst fluid [381,420,424,427,428]. Accumulation is also most prominent with chronic administration of flaxseed lignans compared to acute administrations [213,233,429].

Although lignan accumulation into solid tumors is unknown, tumors commonly possess poorly formed, highly permeable vasculature that results in the accumulation of various macromolecules (e.g., plasma protein albumin) within the tumor microenvironment [430-432]. Several studies have suggested tumors as sites of albumin catabolism, and the presence of putative albumin-binding proteins on tumor cell surfaces [433]. Therefore, taking this into consideration, it is possible that albumin bound lignans may accumulate in the tumor environment independently and/or released upon albumin catabolism, e.g., similar to albumin conjugated drugs used for increasing intratumoral accumulation of drugs for antitumor effects [434]. Similarly, the conjugated metabolites of the aglycone and mammalian lignans may gain easy access to the tumor microenvironment due to the leakiness of the tumor vasculature.

The biological interactions of SECO, ED, ENL, and their phase II conjugates within the molecular and cellular environment remains unclear. Phase II enzyme reactions are typically considered as deactivation pathways. Hence, extensive first-pass metabolism, which results in high levels of circulating phase II conjugates traditionally considered to be inactive metabolites [400], raises questions on how lignans exhibit health benefit following oral consumption. Recent evidence, though, may suggest the conjugative metabolites of the mammalian lignans exert pharmacological activity in certain cellular contexts [435]. Furthermore, evidence exists of the ability of polyphenolic glucuronide conjugates to undergo deconjugation reactions in specific tissues such as the inflammatory sites of the tumor microenvironment due to extracellular availability of $\beta$-glucuronidase, which expresses 
optimal enzyme activity at low pH [142,436-440], as well as evidence of the ability of the vascular endothelium to deconjugate certain glucuronide conjugates $[436,441]$. This suggests that high circulating glucuronide conjugates might act as aglycone carriers with release of the aglycones at target sites upon deconjugation [436,442].

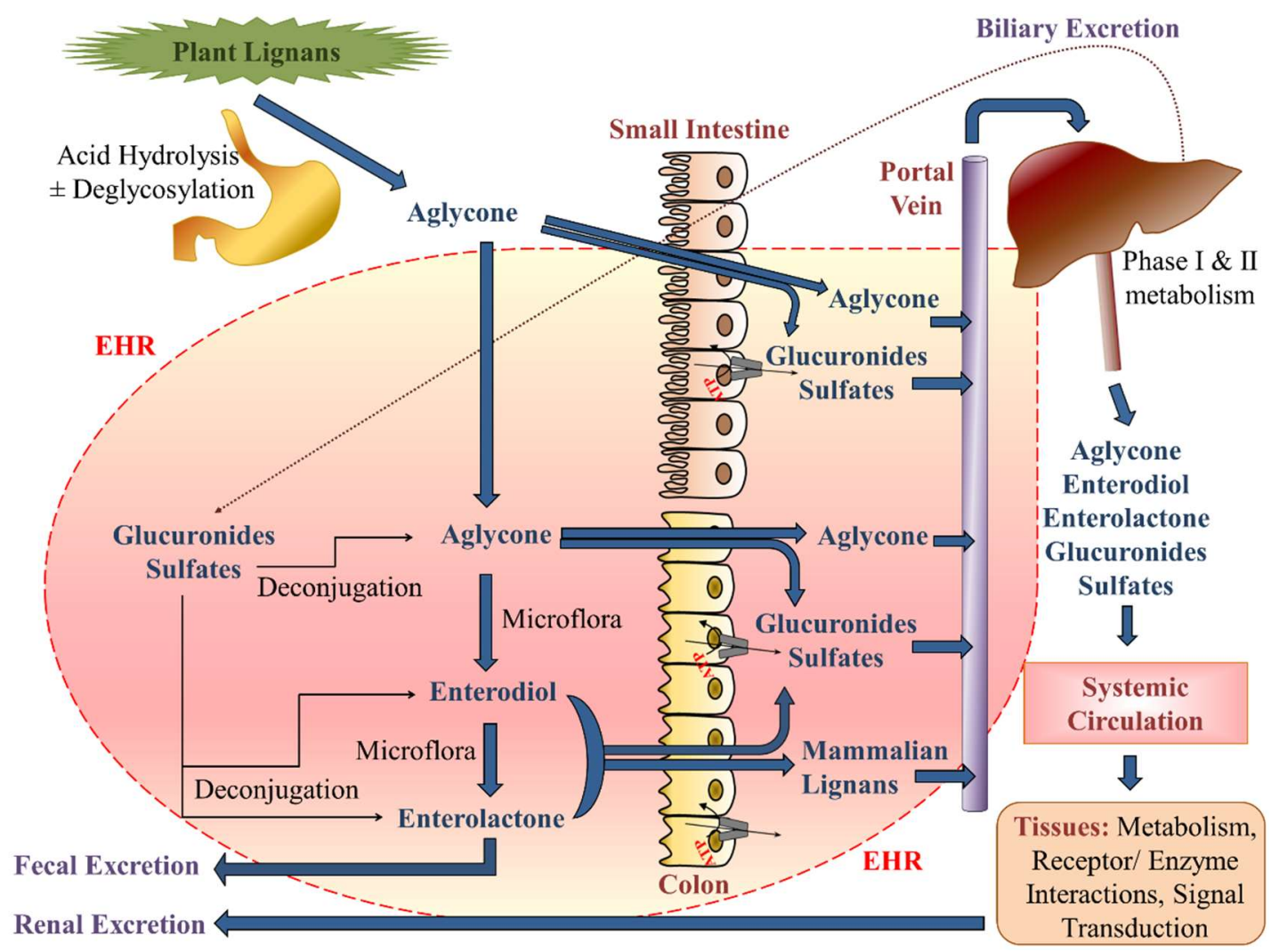

Figure 4. Flaxseed lignan absorption, first-pass metabolism, and enterohepatic recycling. The flaxseed lignan, secoisolariciresinol diglucoside (SDG), is biotransformed by bacteria in the gastrointestinal tract upon oral intake. Due to their lipophilicity, the aglycones and mammalian lignans may cross biological membranes via passive diffusion. With permeation into the enterocyte a portion of the aglycone and mammalian lignans undergo first-pass metabolism by phase II enzymes (e.g., UDP-glucuronosyltransferases (UGT), sulfotransferases (ST)). The polar, water-soluble glucuronide and sulfate conjugates require transport across the basolateral membrane of the intestinal epithelium by active transporters to gain access to the portal blood supply. Unmetabolized aglycone and mammalian lignans enter the hepatocyte by passive diffusion and undergo phase II metabolism by UGTs and STs. The conjugated metabolites are actively transported into the bile and can be reintroduced into the gastrointestinal tract. Here, they can be deconjugated and undergo reabsorption, a process called enterohepatic recirculation (EHR). The various lignans and their corresponding metabolites may elicit biological responses upon entering the systemic circulation by interacting with various enzymes, transporters, and other cell signaling macromolecules. Elimination of the conjugated metabolites can occur through either fecal or renal excretion. Adopted from reference [403].

\subsection{Lignans as Therapeutic Agents for Cancer}

Cancer involves complex mechanistic changes in multiple interdependent and redundant cellular signaling networks that ensure initiation, survival, and promotion of carcinogenesis. This complexity results in many failures of single target therapies in clinical drug development despite the enormous investments made to advance such products to the market [443]. The effects of conventional chemotherapy, though, might be enhanced by compounds that have ability to inhibit and antagonize multiple targets within the complex array of cell signaling processes [444]. This is supported by an 
increased focus on multitarget agents in drug discovery and development, which has gained much needed attention in recent years [445]. The historical presence in the human diet of phytochemicals such as lignans, though, may have an advantage over synthetic compounds due to their coevolutionary exposure. Given their possible multiple therapeutic effects, we have witnessed an increased investment into the investigation of their mechanisms of actions in order to more fully understand their antitumor effects [443].

Flaxseed lignans have a long history of purported health benefits [25,28,38,304] (Figure 5). For cancer, flaxseed is consumed for both chemopreventive and treatment purposes [15,318,446,447]. Studies with preclinical models of cancer clearly have demonstrated therapeutic benefits of lignan rich diets with evidence of reductions in early tumorigenesis [448,449], as well as inhibition of tumor growth, angiogenesis, and progression of the disease [450,451]. Such evidence supports the putative relevance of lignans in carcinogenesis $[1,15,55,174]$. However, clear evidence of benefit in human clinical populations is confounded by the numerous epidemiological and population-based studies that report an unclear accounting of the daily lignan dose and, hence, uncertain lignan exposure levels [325,452-457]. The availability of standardized lignan-enriched products now provides opportunity to clearly understand daily dose exposures and ensure adequate therapeutic levels for clinical benefit. Such lignan-enriched products have demonstrated good safety and tolerability in vulnerable populations, such as frail elderly adults [323,458], as well as in other preclinical and human clinical trials [32,55,459-461], except during pregnancy [462-465] and lactation [420], or with products that produce high ED levels [466,467]. These lignan-enriched products can guarantee pharmacological lignan doses, which will allow us to address past inconclusive epidemiological studies of the effect of lignans (and other polyphenols) on human cancer risk and therapy [55,323,326,333,417,452,468-481].

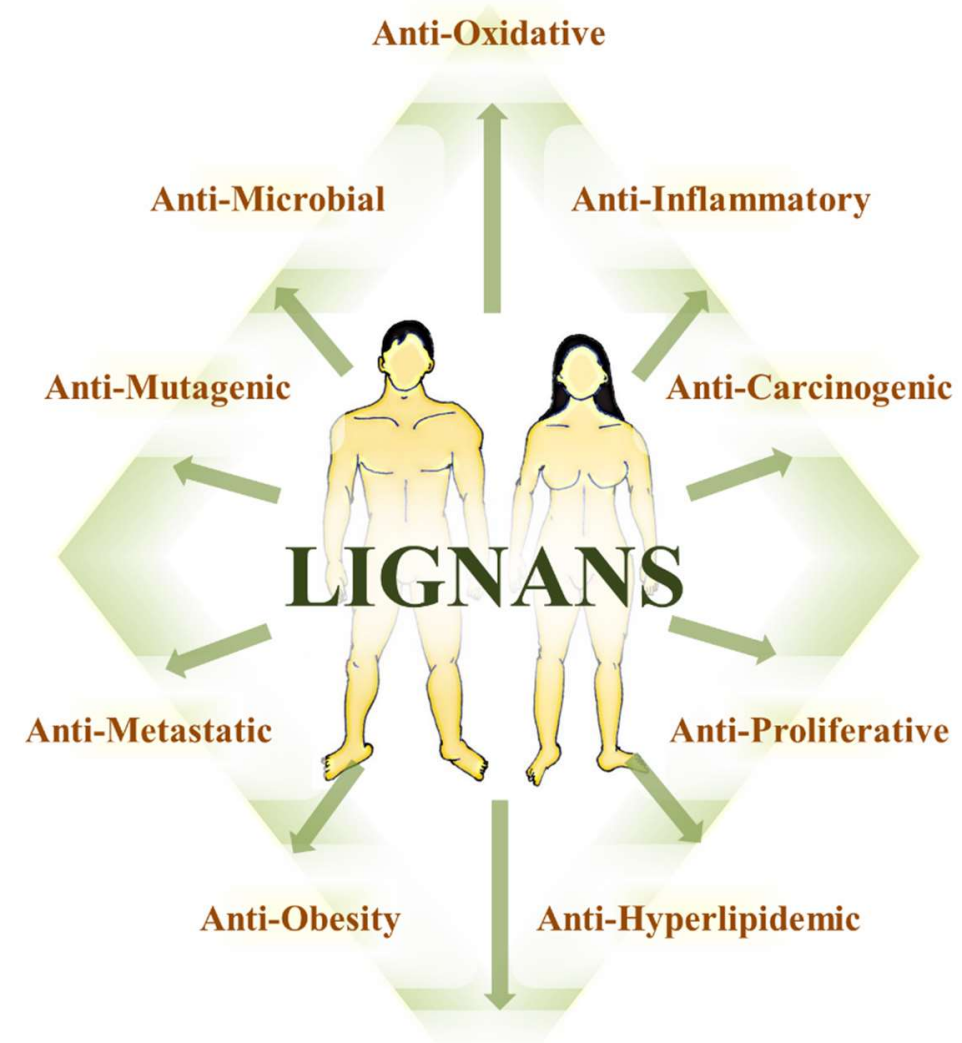

Neuroprotective

Figure 5. Protective health benefits of lignans. Lignans are polyphenolic phytochemicals that have varying biological activities under several contexts. Lignan containing diets or supplements can support general health as well as target many diseases. 


\subsection{Linking Benefits of Flaxseed with Cancer Associated Chronic Diseases}

Cancer shares a number of risk factors common to other chronic disease states [482]. This is emphasized by statistics that indicate cancer, diabetes, and cardiovascular disease (CVD) were responsible for $71 \%$ of deaths globally in 2015 [482]. Chronic diseases, including type 2 diabetes [483-485], and CVD risk factors, such as cholesterol level [486-491], heart rate [492,493], blood pressure [494-498], uric acid [499-503], and chronic kidney disease [504-509], as well as pulmonary disease [510], are associated consistently with the risk of cancer [482]. The abundant evidence confirming the health promoting beneficial effects of flaxseed in chronic disease can be grouped according to health benefits in (1) the cardiovascular system (e.g., platelet aggregation, atherosclerosis, hyperlipidemia, and dyslipidemia [7,9,10,17,19,24,26,27,35,485,511-518]); (2) insulin resistance, glycemic control, and obesity $[9,25,27,35,519-526]$; (3) inflammation $[5,7,8,19,25,27,514,527,528]$ and oxidative stress [5,12,21,23,35,407,513,514,529-534]; (4) hepatic [28,535] and renal systems (e.g., lupus nephritis) $[15,28,435,536]$; (5) the immune and nervous system $[7,15,28,537-543]$; (6) the reproductive system [8,11,14,25,28,33,311,352,514,542,544-546]; and (7) the gut microbiome [547-549]. Detailed discussions on the relationship between chronic disease and flaxseed can be found in our previous review [25] and others [5,6,8,15,16,21,34,304,513]. This collective epidemiological, observational, and preclinical evidence support the idea of flaxseed lignans as qualified candidates for risk reduction and treatment of chronic disease (Table S2) warranting additional clinical trials with known pharmacological doses to provide the evidence base to support their use clinically $[21,513]$.

\subsection{Purposing Lignans into Established Models of Cancer Characteristics}

Several models have been elaborated to describe the wide range of properties and characteristics of cancer [62,550]. These models aid in understanding both the complexity of cancer pathogenesis and the various processes contributing to cancer, as well as to focus research efforts on identifying possible chemopreventive agents or therapeutics [59]. These models provide an organizing framework to explain responses to a targeted therapy, where cancers may modify their dependence on a particular hallmark, while enhancing the activity of another [551]. The "hallmarks of cancer" model established in 2000 by Hanahan and Weinberg identified the six cancer hallmarks of evading growth suppressors, resisting cell death, activating invasion and metastasis, enabling replicative immortality, sustained proliferative signaling, and inducing angiogenesis [63]. This model was subsequently updated in 2011 with further inclusion of two enabling characteristics (genomic instability and tumor-promoting inflammation that support cancer cells to acquire the hallmarks) and two emerging hallmarks (deregulation of cellular energetics and avoidance of immune destruction) [59,62]. In a model (signaling pathways and cellular processes) articulated by Vogelstein et al. in 2013 [550], tumors contain two to eight "driver gene" mutations that drive cancer growth, while the remaining "passenger" mutations do not add to the selective growth advantage [59]. Genes either contain intragenic mutations (Mut-driver genes) or epigenetic alterations (Epi-driver genes), both of which are responsible for carcinogenesis as well as a selective growth advantage. According to this model, twelve major signaling pathways drive cancer growth and include (a) cell survival: PI3K (phosphatidylinositide 3-kinase), MAPK (mitogen-activated protein kinase), RAS (rat sarcoma), STAT (signal transducers and activators of transcription), cell cycle/apoptosis, and TGF $\beta$ (transforming growth factor $\beta$ ); (b) cell fate: NOTCH, HH (Hedgehog), APC (Adenomatous polyposis coli), chromatin modification, and transcriptional regulation; and (c) genome maintenance: DNA damage control related pathways [59]. Finally, K.I. Block's model (pathways of progression and contributing metabolic factors) of nutraceutical-based targeting of cancer lists nine "pathways of progression" (proliferation, apoptosis, treatment resistance, immune evasion, angiogenesis, metastasis, cell-to-cell communication, differentiation, and immortality) and six "metabolic terrain factors" (oxidation, inflammation, glycemia, blood coagulation, immunity, and stress chemistry) that influence the quality of life of all cancer patients [59,552]. Together, these models clearly demonstrate the interrelationships of different signaling network pathways and the enormous number of targets that require interrogation for cancer prevention and therapeutic management. 
Many phytochemicals are known to modulate multiple targets within these complex cancer processes [444,553-556]. In particular, flaxseed lignans may concurrently target various complex interdependent pathways involved in cancer progression and survival raising the possibility that lignans could be incorporated into a design of a broad-spectrum combination chemotherapy [557] (Figure 6). Drug discovery programs today have moved away from the single-target approach and currently consider systems biology approaches to improve pharmacological network understanding [59]. The complexities in tumor heterogeneity and in the interconnections amongst the various growth factors, cytokines, chemokines, transcription factors, and the proteome makes systems biology approaches exceedingly more relevant $[558,559]$. It also makes the broad-spectrum multitargeted approach to cancer highly significant [59]. In recognition of this changing paradigm to cancer discovery, we compiled the known lignan targets alongside their potential identification within the different cancer characteristics models listed above (Table 2).

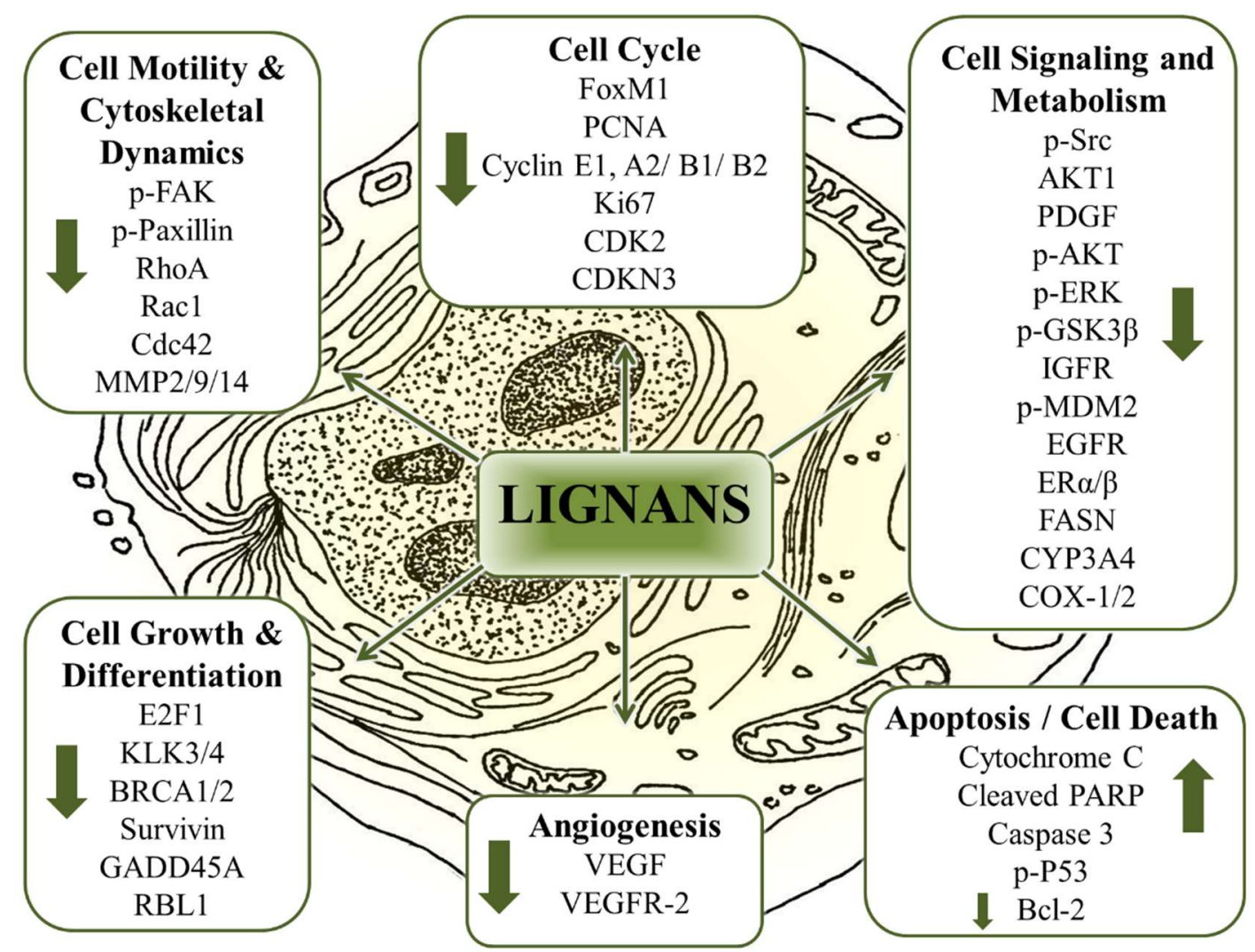

Figure 6. The cellular and molecular targets of lignans. Flaxseed lignans have the ability to target multiple pathways in cancer given the evidence from both in vitro and in vivo evaluations (Table 2). Cancer metastases can be inhibited by the modulation of the cytoskeleton and cell motility processors. Modulation of cell growth and differentiation as well as cell cycle arrest interfere with tumor proliferation and survival. Starving tumors by targeting angiogenesis as well as triggering apoptosis leads to inhibition of progression and survival. Interfering with different cell signaling pathways linking AKT and ERK modulates cell metabolism and disfavors progression and survival.

\subsection{The Multitarget Effects of Lignans in Cancer (Nutridynamics)}

In the following section, the ability of the lignans to influence the cancer phenotype is broadly organized according to the cancer hallmarks [62]. Lignan modulation of a specific target is highlighted under specific areas linked to hallmarks, although any one target might have overlapping function in the different hallmarks. Examples are provided, but due to the complexity and interconnections among molecular signaling networks, flaxseed lignans are able to impact an array of targets leading to the modulation of various signaling cascades in the different stages of the malignant disease to disfavor 
progression. The reader is referred to the review by Teponno et al. [560] for detailed information on other lignans and neolignans.

\subsubsection{Antioxidant and Anti-Inflammatory Properties}

Lignans are well recognized for their antioxidant and anti-inflammatory activities, key properties that contribute to their multitarget effects $[55,561]$. As polyphenolic compounds, lignans can act as direct antioxidants (e.g., direct scavenging of hydroxyl radical) [562] or through indirect mechanisms such as modulation of the expression of antioxidant enzymes [563,564]. A number of in vitro studies have shown the lignans to be effective direct antioxidants [565]. For example, the direct antioxidant activity of SECO, ED, and EL exceeded vitamin E, a typical comparator, by approximately 4.5 to 5 times, with SDG showing similar activity to vitamin E [38,530]. ED and EL are reported to be effective inhibitors of lipid peroxidation in vitro [407], and in a model of lipid autoxidation, SECO showed much better antioxidant activity than SDG [566]. There is no significant difference between SECO/SDG and BHT-a food preservative known to cause liver toxicity-to prevent/delay the autoxidation process [567]. SDG and SECO are effective antioxidants (attributed to the 3-methoxy-4-hydroxyl substituents) against 1,1-diphenyl-2-picrylhydrazyl (DPPH))-initiated peroxyl radical plasmid DNA damage and phosphatidylcholine liposome lipid peroxidation [532]. In an aqueous environment, benzylic hydrogen abstraction and potential resonance stabilization of phenoxyl radicals are likely to aid in the antioxidant activity of the mammalian lignans [532]. Further details on the antioxidant properties of flaxseed lignans can be found in several other reviews [38,568,569]. Despite these direct antioxidant effects in vitro, it is debatable whether lignans attain adequate systemic concentrations with dietary consumption to mediate similar effects in vivo as lignans largely exist as conjugated metabolites.

The indirect antioxidant activity of lignans is mediated through upregulation of a number of antioxidant enzymes and phase II detoxifying enzymes. Upregulation of these enzymes is associated with the nuclear factor erythroid 2 (Nrf2)-linked pathway-a key transcriptional regulator of many antioxidative and anti-inflammatory pathways [570]. Nuclear factor- $\mathrm{kB}$ (NF- $\mathrm{kB}$ ) is a transcription factor that is of importance in inflammation and plays a role in development, cell growth, cell survival, and proliferation [571]. Certain NF-KB-regulated genes play a pivotal role in controlling reactive oxygen species (ROS), but ROS also has various inhibitory/stimulatory effects in NF-kB mediated signaling [571]. Transcriptional regulation by Nrf2 is clearly associated with lignan induction of heme oxygenase-1 (HO-1) expression [562] with subsequent modulation of NF- $\mathrm{KB}$ mediated inflammatory and oxidative pathways [572,573]. Lignans also increase the abundance of antioxidant genes such as superoxide dismutase (SOD), catalase (CAT) and glutathione peroxidase (GPX) [564,574], and induce the expression of glutathione S-transferases (e.g., GSTM1) and $\mathrm{NAD}(\mathrm{P}) \mathrm{H}$ dehydrogenase [quinone] 1 (NQO1) [575,576]. SOD2, SOD1, NQO1, CAT, GST, and GPX are all regulated by NF-кB [571]. SDG in physiological solutions provide DNA radioprotection by scavenging active chlorine species and reducing chlorinated nucleobases [577], suggesting SDG as a promising candidate for radioprotection of normal tissue during cancer radiation therapy [578]. The molecular pathways connected to these various antioxidant activities contribute to the control of multiple cancer hallmarks such as "resisting cell death", "genome instability and mutation", "deregulating cellular energetics", and others depending on the context.

The anti-inflammatory properties of lignans are well-documented and are suggested to benefit chronic inflammatory diseases such as cancer [55,576,579-581]. Lignans can modulate inflammation through several mechanisms including modulation of immune cell activation through interference with NF-kB pathway signaling [408]; reductions in proinflammatory cytokines, such as IL-1B, IL-6, $\mathrm{TNF} \alpha, \mathrm{HMGB} 1$, and TGFß1, and cytokine receptors, TNF $\alpha$ R1 and TGFßR1 [582]; and downregulation of cyclooxygenase enzyme activity and levels [583]. Flaxseed also downregulates microRNA (miRNA) miR-150, which is integrated into immune response-mediated networks [584]. Lignan influence on the inflammatory process clearly impacts the "tumor promoting inflammation" hallmark of cancer. 


\subsubsection{Anticarcinogenic and Antimutagenic Properties}

Carcinogenesis occurs in several stages and mutagenesis supports the progression of the malignant disease. As effective antioxidants against DNA damage and lipid peroxidation [532], lignans are suggested to have chemopreventive properties in cancer, and SDG is emerging as a potential anticarcinogenic agent $[344,582]$. Preclinical in vivo studies that have demonstrated decreased incidence of tumor formation in tumor induction models and reductions in the procarcinogenic microenvironment following flaxseed lignan supplementation, offer support for lignans as chemopreventive agents [583,585-588]. Activation of p53 can induce cell cycle arrest as well as apoptosis in response to DNA damage [589]. The transcriptional activation of target genes of p53 is critical in cell fate determination after genotoxic stress $[589,590]$. Oxygen radical-based alterations at specific nucleotides can lead to mutations that occur when altered bases are copied by DNA polymerases (replicate the genome) [591]. ROS has been attributed to the pathogenesis of liver, lung, and prostate cancers [591]. The use of antioxidant therapy (preventive), such as with the lignans [576,581,582,592], has been suggested to slow tumorigenesis to prevent clinical presentation of cancers [591]. In cancer cell model systems, lignans can modulate the percentage of cells in the different stages of the cell cycle [593], downregulate viral oncogenes E6 and E7, upregulate tumor suppressor p53, and fail to exhibit genotoxicity in cancer cells [588]. However, depending upon the cancer type, p53 status, and lignan concentration, flaxseed lignans may have different effects on cancer prevention and treatment.

Interestingly, the various signaling pathways involved in anticarcinogenic and antimutagenic effects of lignans could be connected to lignan ability to favorably modulate lipid and glucose homeostasis [9,519,537,594-596]. High cholesterol, fat, and glucose levels are known to increase the risk of cancer [491,597-602]. Several studies have shown altered cholesterol metabolism and accumulation within mitochondria of malignant cells seems to favor continuous cell growth, survival, and progression [603-606]. The lignans variably influence targets within cellular energy and lipid homeostasis pathways, including the ability to reduce expression and activity of CPT 1 (carnitine palmitoyltransferase 1$)$, as well as modulate pAMPK (5' adenosine monophosphate-activated protein kinase), PPAR $\alpha$ (peroxisome proliferator-activated receptor alpha), FASN (fatty acid synthase), expression and activity of SREBP1c (sterol regulatory element-binding proteins) and adipogenesis-related genes, such as leptin, adiponectin, glucose transporter 4 (GLUT-4), and PPAR $\gamma$ (peroxisome proliferator-activated receptor gamma) [213,607-610]. Additionally, a recent study reports upregulation of INSIG-1 (insulin-induced gene 1) and alteration in intracellular cholesterol trafficking in Caco2 colorectal adenocarcinoma cells [435]. Collectively, lignan effects on cellular energy metabolism and lipid homeostasis favorably modulate the cancer hallmarks of "deregulated cellular energetics" and "resisting cell death".

\subsubsection{Anti-proliferative properties}

Lignans are known to reduce chemically-induced mammary and colon tumorigenesis [31,345,582]. In addition to their well-known antioxidative and anti-inflammatory effects, lignans are purported phytoestrogens with ability to modulate estrogen receptors and other hormonal functions [611]. Their putative role as phytoestrogens prompted extensive investigation into hormone-dependent cancers, since hormones play a vital role in their etiology influencing rate of cancer cell division, differentiation, survival, and metastasis $[55,612,613]$. Interestingly, lignans demonstrate weak binding properties to estrogen receptor $\alpha(E R \alpha)$ and $E R \beta$ suggesting a limited potential for estrogenic and antiestrogenic activity [614]. Yet, studies suggest lignans' ability to inhibit hormone-dependent cancer cell proliferation, cancer growth, and progression [55,467,615-617]. This may result from such mechanisms as lignan-mediated reduction in the expression of hormonal and growth factor receptor expression or binding affinity (e.g., ER, progesterone receptor (PR), EGFR (epidermal growth factor receptor), and IGF-1R (insulin-like growth factor 1 receptor)) [341,453,618], regulation of plasma sex hormone binding globulin (SHBG) levels $[55,619]$ or binding affinity with endogenous 
hormones [55,620], competition with estradiol for the type II estradiol binding sites (EBS) [621-623], inhibition of aromatase and $17 \beta$-hydroxysteroid dehydrogenase and thereby reducing sex hormone synthesis [55,624-626], modulation of secreted matrix metalloproteinase (MMP) activities [531], and/or alteration in the expression and activity of cell cycle regulators and signal transduction networks regulating cell proliferation, survival, and migration [335,593,613,618,627-629]. The multitarget effects of lignans on hormonal signaling pathways identify their key role in modulating the important cancer hallmark of "sustaining proliferative signaling".

\subsubsection{Dysregulated cellular metabolism}

A common feature of cancer cell metabolism is the ability to obtain nutrients from the nutrient-poor tumor environment to maintain viability and make new biomass [630]. Given the linkage between cell proliferation and cell metabolism [631], the core fluxes such as aerobic glycolysis, de novo lipid biosynthesis, and glutamine-dependent anaplerosis, have been suggested to form a stereotyped platform in order to carry out proliferation [631]. Additionally, regulation of these cellular fluxes are predominantly linked to phosphatidylinositol 3-kinase (PI3K)/protein kinase B (Akt)/mechanistic target of rapamycin (mTOR), hypoxia-inducible factor 1 (HIF-1), and Myc (myelocytomatosis oncogene) mediated signal transduction and gene expression [631]. Interestingly, upregulation of HO-1 is suspected to act through PI3K/Akt and Nrf-2 signaling pathways [632,633]. PI3K/Akt signaling (master regulator of glucose uptake) stimulates mRNA expression of GLUT1 glucose transporter and the translocation of its protein to the cell surface [630]. Akt amplifies the activity of the glycolytic enzymes hexokinase, the first enzyme of the glycolytic pathway (phosphorylates glucose molecules, and prevents their efflux out of the cell), and phosphofructokinase (catalyzes the main irreversible step) [630]. Akt alone also is capable of stimulating glycolysis to restore cell size, viability, mitochondrial potential, and ATP levels [630]. Additionally, constitutively active Akt can prevent reductions in ATP levels, which is usually triggered by the loss of cellular attachment [630]. Lignans have been reported to reduce Akt signaling [618,629,634], as well as HO-1 and Nrf-2 signaling [562]. Therefore, not only the hallmark of "sustaining proliferative signaling" but other hallmarks such as "deregulating cellular energetics", "enabling replicative immortality", and "evading growth suppressors" can be targeted by lignans.

\subsubsection{Antiangiogenic Properties}

Angiogenesis is a complicated process that depends on the type of tumor $[635,636]$. Solid tumors with high vascularization (e.g., ovarian cancer, non-small cell lung cancer, renal cell carcinoma, hepatocellular carcinoma, and colorectal cancer) have been the main focus of the development for antiangiogenic drugs [636,637]. The series of events in this complex process include an initial activation of endothelial cells (EC), which often results in the release of proteases that causes the degradation of the basement membranes in the surrounding area of existing vessels, and the migration of ECs to the growing lesion, followed by extensive cell proliferation forming tubes for new blood vessels [635]. However, unlike normal tissue angiogenesis, tumor blood vessel network is disorganized and leaky [638]. Lignans may have a role as effective agents in targeting the hallmark "inducing angiogenesis". Lignans were shown to inhibit estradiol-induced tumor growth and angiogenesis in vivo [451]. The antiangiogenesis activity may relate to ability of lignans to reduce extracellular cancer stroma-derived vascular endothelial growth factor (VEGF) and increase in placenta growth factor (PIGF), a VEGF family member [331,451]. The platelet-derived growth factor (PDGF), its receptor, PDGFR, fibroblast growth factor (FGF) and its receptor, FGFR pathways, can aid in compensatory escape mechanisms facilitating tumor growth from anti-VEGF/VEGFR therapy drugs, which has been the gold standard pharmaceutical target [636]. However, current antiangiogenic strategy is investigating novel and emerging agents that target multiple pathways for treatment [636]. Interestingly, lignans also modulate PDGF signaling pathways making it a multitargeted agent to suppress tumor growth [628]. 


\subsubsection{Anti-invasive and Antimigratory Properties}

The lignans can modulate a number of key targets to reduce cancer cell propensity for invasion and migration $[13,32,55,330,331,467,618,639]$. Lignans were shown to reduce metastasis in an experimental model of melanoma [108,582]. They demonstrate ability to inhibit matrix metalloproteinases (MMPs), the enzymes responsible for degradation of the extracellular matrix (ECM) [55,640-642], modulate the phosphorylation of FAK (focal adhesion kinase), Src (proto-oncogene nonreceptor tyrosine protein kinase Src), and Paxillin, with subsequent modulation of their key targets (e.g., uPA (urokinase-type plasminogen activator), PAI-1 (plasminogen activator inhibitor-1), TIMP-1 (TIMP metallopeptidase inhibitor 1) and TIMP-2, RhoA (Ras homolog gene family, member A), Rac1 (Ras-related C3 botulinum toxin substrate 1), Cdc42 (cell division control protein 42 homolog), and ITGA2 (Integrin subunit alpha 2)) $[627,628]$, and inhibit organization of the actin cytoskeleton to influence cell motility and clonogenicity $[627,628,642,643]$. Given that cancer relapse and metastasis continue to challenge effective chemotherapy $[644,645]$, such properties suggest a potential for the use of lignans to target this cancer hallmark.

\subsubsection{Induction of Apoptosis and Cell Death}

Apoptosis plays a pivotal role in the pathogenesis of cancer where limited apoptosis results in survival of malignant cells. The complex mechanism of apoptosis is linked to many cell signaling pathways where deregulation can cause malignant transformation, metastasis, and resistance to anticancer drugs [646]. Consequently, lignan-mediated enhancement of apoptosis can occur through many mechanisms that are generally categorized into disruption of mitochondrial membrane potential (mitochondrial mediated cell death) $[55,629,634]$, and activation of the intrinsic or extrinsic apoptotic pathways through mechanisms such as TRAIL (tumor necrosis factor (TNF)-related apoptosis-inducing ligand)-induced BID (BH3 interacting-domain death agonist) cleavage [629], reduction in antiapoptosis proteins, Bcl-2 (B-cell lymphoma 2) and survivin [22,588], caspase dependent cell death [634], and death receptor-sensitization through decreased expression of death receptor DR4 expression and TRAIL-DISC (death-inducing signaling complex) proteins, c-FLIPL/S (cellular FLICE-inhibitory protein: short form; FLICE: (Fas-associated death domain-like interleukin $1 \beta$-converting enzyme) and caspase-8, and pGSK-3 $\beta$ (glycogen synthase kinase 3 beta) $[629,634]$. Flaxseed along with radiation therapy have reported to significantly decrease the p53-responsive miRNA, miR-34a, which is responsible for regulating cellular senescence and apoptosis related factors [584]. Dietary flaxseed lignan complex, mainly consisting of SDG, induced radiosensitizing effects in a model of metastatic lung cancer. SDG is protective against radiation pneumonopathy, decreasing lung injury and eventual fibrosis, while improving survival indicating its ability to selectively target malignant cells but spare normal cells [576,581]. Although specific targeting of apoptosis can be associated with safety issues [646], as one of multiple hallmarks influenced by lignans, the ability to enhance cell death is an important attribute of the role of lignans in the therapeutic management of cancer. 
Table 2. Cellular targets modulated by flaxseed lignan and lignan metabolites in cancer ${ }^{1}$.

\begin{tabular}{|c|c|c|c|c|}
\hline $\begin{array}{l}\text { Experimental System } \\
\text { and Lignan* }\end{array}$ & $\begin{array}{l}\text { Targets: Molecules } \\
\text { (Protein/Gene) }\end{array}$ & Block's Model & $\begin{array}{c}\text { Hanahan and } \\
\text { Weinberg's Model }\end{array}$ & $\begin{array}{l}\text { Vogelstein et al., } \\
\text { Model }\end{array}$ \\
\hline \multirow{3}{*}{$\begin{array}{l}\text { MDA-MB231 (BC) } \\
\text { ENL * }\end{array}$} & $\begin{array}{c}\downarrow \text { Ki67, } \downarrow \text { PCNA, } \downarrow \text { FoxM1, } \\
\downarrow \text { Cyclin E1, } \downarrow \text { Cyclin A2, } \\
\downarrow \text { Cyclin B1 } \downarrow \text { Cyclin B2 [627] }\end{array}$ & $\begin{array}{c}\text { Proliferation, } \\
\text { Immortality, } \\
\text { Treatment resistance }\end{array}$ & $\begin{array}{c}\text { Sustaining } \\
\text { proliferative } \\
\text { signaling, Evading } \\
\text { growth } \\
\text { suppressors }\end{array}$ & Cell survival \\
\hline & $\begin{array}{c}\downarrow \text { pFAK, } \downarrow \text { pPaxillin [627] } \\
\downarrow \text { ERK- } 1 / 2, \downarrow N F-\kappa B \\
\downarrow \text { MAPK-p38, } \downarrow \text { CD44 [647] }\end{array}$ & $\begin{array}{c}\text { Proliferation, } \\
\text { Metastasis, } \\
\text { Cell-to-cell } \\
\text { communication and } \\
\text { Immortality } \\
\end{array}$ & $\begin{array}{l}\text { Activating invasion } \\
\text { \& metastasis, } \\
\text { Sustaining } \\
\text { proliferative } \\
\text { signaling }\end{array}$ & $\begin{array}{l}\text { Cell survival, Cell } \\
\text { fate }\end{array}$ \\
\hline & $\begin{array}{c}\downarrow \text { uPA, } \downarrow \text { MMP-2, } \downarrow \text { MMP-9, } \\
\uparrow \text { PAI-1, } \uparrow \text { TIMP-1, } \uparrow \text { TIMP-2 } \\
\text { [643] } \\
\downarrow \text { N-cadherin, } \downarrow \text { vimentin, } \\
\uparrow \text { E-cadherin, } \uparrow \text { occludin, } \\
\downarrow \text { Snail [647] }\end{array}$ & $\begin{array}{l}\text { Differentiation, } \\
\text { Metastasis }\end{array}$ & $\begin{array}{l}\text { Activating invasion } \\
\text { \& metastasis }\end{array}$ & Cell fate \\
\hline $\begin{array}{l}\text { XM (MDA-MB231) } \\
\text { SDG * }\end{array}$ & 个LIV-1, $\downarrow$ ZIP2, ZnT-1 [648] & Proliferation & $\begin{array}{l}\text { Sustaining } \\
\text { proliferative } \\
\text { signaling }\end{array}$ & Cell survival \\
\hline $\begin{array}{l}\text { MO (basal-like BC) } \\
\text { SDG * }\end{array}$ & $\begin{array}{l}\downarrow \text { Proinflammatory markers } \\
(\mathrm{F} 4 / 80, \mathrm{CRP}), \downarrow \text { p-p65 [649] }\end{array}$ & Inflammation & $\begin{array}{l}\text { Tumor promoting } \\
\text { inflammation }\end{array}$ & Cell survival \\
\hline $\begin{array}{l}\mathrm{MO}(\mathrm{MCF7})(\mathrm{BC}) \\
\mathrm{ENL}^{*}\end{array}$ & $\downarrow$ VEGF, $\uparrow$ PIGF [331] & $\begin{array}{l}\text { Proliferation, } \\
\text { Treatment resistance, } \\
\text { Angiogenesis }\end{array}$ & $\begin{array}{l}\text { Inducing } \\
\text { angiogenesis }\end{array}$ & Cell survival \\
\hline \multirow{2}{*}{$\begin{array}{l}\text { OVX MO (MCF-7) } \\
\text { SDG * }\end{array}$} & $\begin{array}{l}\downarrow \text { ER } \alpha, \downarrow \text { ER } \beta, \downarrow \text { EGFR }, \downarrow \text { pS2 } \\
\quad \downarrow \text { IGF-1R, } \downarrow \text { BCL2 [341] }\end{array}$ & $\begin{array}{l}\text { Apoptosis, } \\
\text { Proliferation, } \\
\text { Glycemia }\end{array}$ & $\begin{array}{c}\text { Sustaining } \\
\text { proliferative } \\
\text { signaling, Resisting } \\
\text { cell death }\end{array}$ & Cell survival \\
\hline & $\downarrow$ pMAPK [341] & Proliferation & $\begin{array}{l}\text { Sustaining } \\
\text { proliferative } \\
\text { signaling }\end{array}$ & Cell survival \\
\hline $\begin{array}{l}\text { MCF7, MDA-MB231 } \\
\text { ENL * }^{*}\end{array}$ & $\begin{array}{c}\downarrow \text { MMP2, } \downarrow \text { MMP9 } \downarrow \text { MMP14, } \\
\pm \text { MMP11 [642] }\end{array}$ & $\begin{array}{l}\text { Differentiation, } \\
\text { Metastasis }\end{array}$ & $\begin{array}{l}\text { Activating invasion } \\
\quad \& \text { metastasis }\end{array}$ & Cell fate \\
\hline \multirow{3}{*}{$\begin{array}{l}\text { A549, H60 (Lung } \\
\text { cancer) } \\
\text { ENL * }^{*}\end{array}$} & $\underset{[\mathrm{pFAK}, \downarrow \mathrm{pSrc}, \downarrow \text { pPaxillin }}{[628]}$ & $\begin{array}{l}\text { Proliferation, } \\
\text { Metastasis, } \\
\text { Cell-to-cell } \\
\text { communication }\end{array}$ & $\begin{array}{l}\text { Activating invasion } \\
\text { \& metastasis, } \\
\text { Sustaining } \\
\text { proliferative } \\
\text { signaling }\end{array}$ & $\begin{array}{l}\text { Cell survival, Cell } \\
\text { fate }\end{array}$ \\
\hline & $\downarrow$ RhoA, $\downarrow$ Rac1, $\downarrow$ Cdc42 [628] & $\begin{array}{c}\text { Metastasis, } \\
\text { Cell-to-cell } \\
\text { communication }\end{array}$ & $\begin{array}{l}\text { Activating invasion } \\
\text { \& metastasis }\end{array}$ & Cell fate \\
\hline & $\begin{array}{c}\uparrow \downarrow F A K, \text { PDGF signaling } \\
\text { (AKT1, CCND3). } \downarrow \text { RhoA, } \\
\text { Rac1, Cdc42, } \uparrow \text { ITGA2 [628] }\end{array}$ & $\begin{array}{l}\text { Metastasis, } \\
\text { Differentiation, } \\
\text { Proliferation, } \\
\text { Cell-to-cell } \\
\text { communication }\end{array}$ & $\begin{array}{l}\text { Activating invasion } \\
\text { \& metastasis, } \\
\text { Sustaining } \\
\text { proliferative } \\
\text { signaling }\end{array}$ & $\begin{array}{l}\text { Cell survival, Cell } \\
\text { fate }\end{array}$ \\
\hline \multirow{2}{*}{$\begin{array}{l}\text { MG-63 (Osteosarcoma) } \\
\text { ENL and ED * }\end{array}$} & $\begin{array}{c}\text { Biphasic }(\uparrow \downarrow) \text { - osteonectin, } \\
\text { collagen I [650] }\end{array}$ & $\begin{array}{l}\text { Proliferation, } \\
\text { Differentiation, } \\
\text { Cell-to-cell } \\
\text { communication }\end{array}$ & $\begin{array}{l}\text { Activating invasion } \\
\quad \& \text { metastasis }\end{array}$ & Cell fate \\
\hline & $\begin{array}{l}\uparrow A L P, \uparrow o s t e o p o n t i n, \\
\uparrow o s t e o c a l c i n[650]\end{array}$ & $\begin{array}{l}\text { Proliferation, } \\
\text { Differentiation, } \\
\text { Metastasis, } \\
\text { Cell-to-cell } \\
\text { communication }\end{array}$ & $\begin{array}{l}\text { Activating invasion } \\
\text { \& metastasis }\end{array}$ & Cell fate \\
\hline
\end{tabular}


Table 2. Cont.

\begin{tabular}{|c|c|c|c|c|}
\hline $\begin{array}{l}\text { Experimental System } \\
\text { and Lignan* }\end{array}$ & $\begin{array}{l}\text { Targets: Molecules } \\
\text { (Protein/Gene) }\end{array}$ & Block's Model & $\begin{array}{c}\text { Hanahan and } \\
\text { Weinberg's Model }\end{array}$ & $\begin{array}{c}\text { Vogelstein et al., } \\
\text { Model }\end{array}$ \\
\hline $\begin{array}{l}\text { WPMY-1 (PS) } \\
\text { ENL * }\end{array}$ & $\begin{array}{c}\uparrow \text { GPER, } \uparrow p-E R K, \uparrow P 53, \uparrow P 21, \\
\downarrow \text { Cyclin D1 [651] }\end{array}$ & $\begin{array}{l}\text { Proliferation, } \\
\text { Immortality }\end{array}$ & $\begin{array}{l}\text { Sustaining } \\
\text { proliferative } \\
\text { signaling }\end{array}$ & Cell survival \\
\hline $\begin{array}{l}\text { Rat prostate } \\
\text { SDG * }\end{array}$ & 个GPER [651] & $\begin{array}{l}\text { Proliferation, } \\
\text { Immortality }\end{array}$ & $\begin{array}{l}\text { Sustaining } \\
\text { proliferative } \\
\text { signaling }\end{array}$ & Cell survival \\
\hline \multirow{2}{*}{$\begin{array}{l}\text { WPE1-NA22, } \\
\text { WPE1-NB14, } \\
\text { WPE1-NB11, } \\
\text { WPE1-NB26 and } \\
\text { LNCaP (PC) } \\
\text { ENL * }\end{array}$} & $\begin{array}{c}\uparrow \downarrow D N A \text { licensing genes } \\
\text { (GMNN, CDT1, MCM2, } \\
\text { MCM7) [593] }\end{array}$ & $\begin{array}{c}\text { Proliferation, } \\
\text { Immortality, } \\
\text { Treatment resistance }\end{array}$ & $\begin{array}{l}\text { Sustaining } \\
\text { proliferative } \\
\text { signaling }\end{array}$ & $\begin{array}{l}\text { Cell survival, } \\
\text { Genome } \\
\text { maintenance }\end{array}$ \\
\hline & $\begin{array}{c}\downarrow \mathrm{miR}-106 \mathrm{~b} \text { cluster } \\
\text { (miR-106b, miR-93, } \\
\text { miR-25), } \uparrow \text { PTEN [593] }\end{array}$ & $\begin{array}{l}\text { Proliferation, } \\
\text { Angiogenesis }\end{array}$ & $\begin{array}{l}\text { Sustaining } \\
\text { proliferative } \\
\text { signaling } \\
\end{array}$ & Cell survival \\
\hline \multirow[b]{2}{*}{$\begin{array}{l}\mathrm{LNCaP} \\
\mathrm{ENL}^{*}\end{array}$} & $\begin{array}{c}\downarrow \text { BRCA1, } \downarrow \text { CDK2, } \downarrow \text { CDKN3, } \\
\downarrow \text { E2F1, } \downarrow \text { KLK3, } \downarrow \text { KLK4 }, \\
\downarrow \text { PCNA, } \downarrow \text { PIAS1, } \downarrow \text { PRKCD }, \\
\downarrow \text { PRKCH }, \downarrow \text { RASSF1, } \downarrow \text { TPM1 } \\
\downarrow \text { SLC43A1 }[335]\end{array}$ & $\begin{array}{l}\text { Proliferation, } \\
\text { Immortality, } \\
\text { Differentiation, } \\
\text { Treatment resistance }\end{array}$ & $\begin{array}{l}\text { Sustaining } \\
\text { proliferative } \\
\text { signaling, } \\
\text { Replicative } \\
\text { immortality, } \\
\text { Evading growth } \\
\text { suppressors }\end{array}$ & $\begin{array}{c}\text { Cell survival, } \\
\text { Genome } \\
\text { maintenance Cell } \\
\text { fate }\end{array}$ \\
\hline & 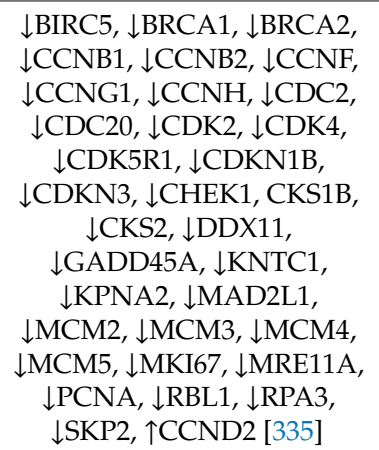 & $\begin{array}{l}\text { Proliferation, } \\
\text { Immortality, } \\
\text { Treatment resistance, } \\
\text { Stress chemistry }\end{array}$ & $\begin{array}{c}\text { Sustaining } \\
\text { proliferative } \\
\text { signaling, Evading } \\
\text { growth } \\
\text { suppressors }\end{array}$ & $\begin{array}{c}\text { Genome } \\
\text { maintenance, Cell } \\
\text { survival }\end{array}$ \\
\hline \multirow{4}{*}{$\begin{array}{l}\text { LNCaP } \\
\text { MAT * }\end{array}$} & $\downarrow$ pAKT [629] & $\begin{array}{c}\text { Treatment resistance, } \\
\text { Apoptosis, } \\
\text { Proliferation, } \\
\text { Glycemia }\end{array}$ & $\begin{array}{l}\text { Sustaining } \\
\text { proliferative } \\
\text { signaling }\end{array}$ & Cell survival \\
\hline & $\downarrow D R 4$ [629] & $\begin{array}{l}\text { Apoptosis, } \\
\text { Proliferation, } \\
\text { Immortality }\end{array}$ & Resisting cell death & $\begin{array}{l}\text { Cell survival, Cell } \\
\text { fate }\end{array}$ \\
\hline & $\begin{array}{c}\downarrow \text { TRAIL-DISC proteins } \\
\text { (c-FLIP L/S, caspase-8) [629] }\end{array}$ & $\begin{array}{l}\text { Apoptosis, } \\
\text { Proliferation }\end{array}$ & $\begin{array}{c}\text { Sustaining } \\
\text { proliferative } \\
\text { signaling, Resisting } \\
\text { cell death }\end{array}$ & $\begin{array}{l}\text { Cell survival, Cell } \\
\text { fate }\end{array}$ \\
\hline & $\begin{array}{l}\text { 个TRAIL-induced BID } \\
\text { cleavage [629] }\end{array}$ & $\begin{array}{l}\text { Apoptosis, } \\
\text { Proliferation }\end{array}$ & Resisting cell death & Cell survival \\
\hline \multirow{3}{*}{$\begin{array}{l}\text { LNCaP } \\
\text { ENL * }\end{array}$} & $\begin{array}{c}\uparrow \text { Cytochrome c release, } \\
\uparrow \text { cleaved caspase-3, } \uparrow \text { PARP } \\
\text { [634] }\end{array}$ & $\begin{array}{l}\text { Apoptosis, } \\
\text { Proliferation, } \\
\text { Glycemia, } \\
\text { Immortality, } \\
\text { Oxidation }\end{array}$ & $\begin{array}{c}\text { Deregulated } \\
\text { cellular energetics, } \\
\text { and Genome } \\
\text { instability and } \\
\text { mutation }\end{array}$ & Cell survival \\
\hline & $\begin{array}{l}\downarrow \text { pAKT, } \downarrow \text { pGSK-3 } \beta, \\
\downarrow \text { pMDM2, } \uparrow \text { P53 [634] }\end{array}$ & $\begin{array}{l}\text { Apoptosis, } \\
\text { Immortality, } \\
\text { Proliferation }\end{array}$ & $\begin{array}{c}\text { Sustaining } \\
\text { proliferative } \\
\text { signaling, Evading } \\
\text { growth } \\
\text { suppressors, } \\
\text { Enabling } \\
\text { replicative } \\
\text { immortality }\end{array}$ & Cell survival \\
\hline & $\uparrow$ Caspase cell death [634] & Apoptosis & Resisting cell death & Cell survival \\
\hline
\end{tabular}


Table 2. Cont

\begin{tabular}{|c|c|c|c|c|}
\hline $\begin{array}{l}\text { Experimental System } \\
\text { and Lignan* }\end{array}$ & $\begin{array}{l}\text { Targets: Molecules } \\
\text { (Protein/Gene) }\end{array}$ & Block's Model & $\begin{array}{c}\text { Hanahan and } \\
\text { Weinberg's Model }\end{array}$ & $\begin{array}{l}\text { Vogelstein et al., } \\
\text { Model }\end{array}$ \\
\hline \multirow{3}{*}{$\begin{array}{l}\text { PC3 (PC) } \\
\text { ENL * }\end{array}$} & $\begin{array}{c}\downarrow \text { pIGF-R(IGF-1), } \downarrow \text { pAKT, } \\
\downarrow \text { p-p70S6K1, } \text { pGSK3 } \beta, \\
\downarrow \text { pCyclinD1, } \downarrow \text { pERK } \frac{1}{2}[618]\end{array}$ & $\begin{array}{l}\text { Proliferation, } \\
\text { Glycemia, } \\
\text { Immortality }\end{array}$ & $\begin{array}{c}\text { Sustaining } \\
\text { proliferative } \\
\text { signaling, } \\
\text { Activating invasion } \\
\text { \& metastasis }\end{array}$ & $\begin{array}{l}\text { Cell survival, Cell } \\
\text { fate }\end{array}$ \\
\hline & $\downarrow$ IGF-1 signaling [618] & $\begin{array}{l}\text { Proliferation, } \\
\text { Glycemia }\end{array}$ & $\begin{array}{l}\text { Sustaining } \\
\text { proliferative } \\
\text { signaling }\end{array}$ & $\begin{array}{l}\text { Cell survival, Cell } \\
\text { fate }\end{array}$ \\
\hline & $\downarrow$ FASN [213] & $\begin{array}{l}\text { Proliferation, } \\
\text { Treatment resistance }\end{array}$ & $\begin{array}{c}\text { Sustaining } \\
\text { proliferative } \\
\text { signaling, } \\
\text { Deregulated } \\
\text { cellular energetics }\end{array}$ & Cell survival \\
\hline $\begin{array}{l}\text { HUVEC (endothelial) } \\
\text { ENL * }\end{array}$ & $\downarrow$ VEGFR-2 [331] & $\begin{array}{l}\text { Proliferation, } \\
\text { Angiogenesis }\end{array}$ & $\begin{array}{c}\text { Inducing } \\
\text { angiogenesis }\end{array}$ & Cell survival \\
\hline $\begin{array}{l}\text { Adipocytes } \\
\text { ENL* }\end{array}$ & $\begin{array}{c}\downarrow \text { ROS - oxidative damage, } \\
\downarrow \text { DNMTs, } \downarrow \text { HDACs, } \downarrow \text { MBD2 } \\
{[334]}\end{array}$ & $\begin{array}{c}\text { Proliferation, } \\
\text { Oxidation, } \\
\text { Inflammation, Stress } \\
\text { chemistry, } \\
\text { Immortality }\end{array}$ & & $\begin{array}{l}\text { Cell fate, Genome } \\
\text { maintenance }\end{array}$ \\
\hline $\begin{array}{l}\text { Colonocytes-YAMC } \\
\text { ENL and ED * }\end{array}$ & $\downarrow$ Cyclin D1, $\downarrow$ Bcl-2 [586] & $\begin{array}{l}\text { Proliferation, } \\
\text { Immortality, } \\
\text { Apoptosis }\end{array}$ & $\begin{array}{c}\text { Sustaining } \\
\text { proliferative } \\
\text { signaling, Resisting } \\
\text { cell death }\end{array}$ & Cell survival \\
\hline $\begin{array}{c}\text { Colo201 (COC) } \\
\text { ENL * }^{*}\end{array}$ & $\begin{array}{c}\downarrow \mathrm{Bcl}-2, \downarrow \mathrm{PCNA}, \uparrow \text { cleaved } \\
\text { caspase-3 }[22]\end{array}$ & $\begin{array}{l}\text { Apoptosis, } \\
\text { Proliferation }\end{array}$ & Resisting cell death & Cell survival \\
\hline $\begin{array}{l}\text { Apc-Min (intestinal) } \\
\text { Diet (flaxseed) }{ }^{*}\end{array}$ & $\downarrow$ COX-1, COX-2 [652] & $\begin{array}{l}\text { Proliferation, } \\
\text { Immortality, } \\
\text { Inflammation }\end{array}$ & $\begin{array}{l}\text { Sustaining } \\
\text { proliferative } \\
\text { signaling, Tumor } \\
\text { promoting } \\
\text { inflammation }\end{array}$ & Cell survival \\
\hline \multirow[b]{2}{*}{$\begin{array}{c}\text { Hens } \\
\text { Flaxseed supplement * }\end{array}$} & $\downarrow$ COX-2 [583] & $\begin{array}{l}\text { Proliferation, } \\
\text { Immortality, } \\
\text { Inflammation }\end{array}$ & $\begin{array}{l}\text { Tumor promoting } \\
\text { inflammation }\end{array}$ & Cell survival \\
\hline & $\begin{array}{c}\downarrow \text { Prostaglandin E2, } \downarrow \text { ER } \alpha, \\
\downarrow \text { CYP3A4, } \downarrow \text { CYP1B1, } \\
\downarrow 16-\text { OHE1, } \uparrow \text { CYP1A1, } \\
\uparrow 2-\text { OHE1 [583] }\end{array}$ & $\begin{array}{c}\text { Proliferation, } \\
\text { Inflammation, } \\
\text { Treatment resistance, } \\
\text { Stress chemistry }\end{array}$ & $\begin{array}{l}\text { Tumor promoting } \\
\text { inflammation }\end{array}$ & Cell survival \\
\hline \multirow{3}{*}{$\begin{array}{l}\text { Hela (CC) } \\
\text { ENL * }\end{array}$} & $\downarrow$ Viral oncogene E6 [588] & Proliferation & $\begin{array}{l}\text { Evading growth } \\
\text { suppressors }\end{array}$ & Cell survival \\
\hline & $\downarrow$ Survivin [588] & $\begin{array}{l}\text { Apoptosis, } \\
\text { Proliferation }\end{array}$ & $\begin{array}{l}\text { Resisting cell death, } \\
\text { Sustaining } \\
\text { proliferative } \\
\text { signaling }\end{array}$ & Cell survival \\
\hline & 个pHistone H2AX [588] & $\begin{array}{l}\text { Apoptosis, } \\
\text { Immortality, } \\
\text { Proliferation }\end{array}$ & Resisting cell death & $\begin{array}{l}\text { Cell survival, Cell } \\
\text { fate }\end{array}$ \\
\hline $\begin{array}{l}\text { Hela } \\
\text { ED * }\end{array}$ & $\uparrow$ Caspase 3 [588] & Apoptosis & Resisting cell death & Cell survival \\
\hline \multirow{2}{*}{$\begin{array}{l}\text { CaSki (CC) } \\
\text { ENL * }\end{array}$} & $\downarrow$ Viral oncogene E7 [588] & Proliferation & $\begin{array}{l}\text { Evading growth } \\
\text { suppressors }\end{array}$ & Cell survival \\
\hline & $\downarrow \mathrm{Bcl}-2[588]$ & $\begin{array}{l}\text { Apoptosis, Treatment } \\
\text { resistance }\end{array}$ & Resisting cell death & Cell survival \\
\hline
\end{tabular}


Table 2. Cont

\begin{tabular}{|c|c|c|c|c|}
\hline $\begin{array}{l}\text { Experimental System } \\
\text { and Lignan * }\end{array}$ & $\begin{array}{l}\text { Targets: Molecules } \\
\text { (Protein/Gene) }\end{array}$ & Block's Model & $\begin{array}{c}\text { Hanahan and } \\
\text { Weinberg's Model }\end{array}$ & $\begin{array}{l}\text { Vogelstein et al., } \\
\text { Model }\end{array}$ \\
\hline \multirow{2}{*}{$\begin{array}{l}\text { Hela and CaSki } \\
\text { ENL * }\end{array}$} & $\uparrow$ P53 [588] & $\begin{array}{l}\text { Proliferation, } \\
\text { Apoptosis }\end{array}$ & $\begin{array}{l}\text { Evading growth } \\
\text { suppressors }\end{array}$ & $\begin{array}{l}\text { Cell survival, } \\
\text { Genome } \\
\text { maintenance }\end{array}$ \\
\hline & $\uparrow \operatorname{Bax}[588]$ & $\begin{array}{l}\text { Apoptosis, Treatment } \\
\text { resistance }\end{array}$ & Resisting cell death & Cell survival \\
\hline \multicolumn{5}{|c|}{$\begin{array}{l}\text { Targets: Cellular } \\
\text { Processors }\end{array}$} \\
\hline $\begin{array}{c}\text { SKBR3 and } \\
\text { MDA-MB231 (BC) } \\
\text { ENL * }^{*}\end{array}$ & $\begin{array}{c}\downarrow \text { Cell viability with } \\
\text { anticancer agents }[55,608]\end{array}$ & $\begin{array}{l}\text { Proliferation, } \\
\text { Treatment resistance, } \\
\text { Stress chemistry, } \\
\text { Apoptosis }\end{array}$ & $\begin{array}{l}\text { Resisting cell death, } \\
\text { Sustaining } \\
\text { proliferative } \\
\text { signaling, Evading } \\
\text { growth } \\
\text { suppressors }\end{array}$ & Cell survival \\
\hline \multirow{5}{*}{$\begin{array}{l}\text { MDA-MB231 } \\
\text { ENL * }\end{array}$} & $\begin{array}{l}\uparrow \text { Cell cycle } S \text { phase, } \downarrow \text { cell } \\
\text { viability [627] }\end{array}$ & $\begin{array}{l}\text { Apoptosis, } \\
\text { Immortality, } \\
\text { Proliferation }\end{array}$ & $\begin{array}{c}\text { Sustaining } \\
\text { proliferative } \\
\text { signaling, Evading } \\
\text { growth } \\
\text { suppressors } \\
\end{array}$ & $\begin{array}{l}\text { Cell survival, } \\
\text { Genome } \\
\text { maintenance, Cell } \\
\text { fate }\end{array}$ \\
\hline & $\begin{array}{c}\downarrow \text { Actin cytoskeleton } \\
\text { organization }[627,647] \\
\downarrow \begin{array}{c}\downarrow \text { Epithelial-mesenchymal } \\
\text { transition }[647]\end{array}\end{array}$ & $\begin{array}{l}\text { Proliferation, } \\
\text { Metastasis }\end{array}$ & $\begin{array}{c}\text { Sustaining } \\
\text { proliferative } \\
\text { signaling, } \\
\text { Activating invasion } \\
\text { \& metastasis } \\
\end{array}$ & $\begin{array}{l}\text { Cell survival, Cell } \\
\text { fate }\end{array}$ \\
\hline & $\begin{array}{c}\downarrow \text { Migration, invasion } \\
{[627,642]}\end{array}$ & Metastasis & $\begin{array}{l}\text { Activating invasion } \\
\text { \& metastasis }\end{array}$ & Cell fate \\
\hline & $\begin{array}{l}\downarrow \text { Actin, filopodia, } \\
\text { lamellipodia [642] }\end{array}$ & $\begin{array}{l}\text { Proliferation, } \\
\text { Metastasis }\end{array}$ & $\begin{array}{c}\text { Sustaining } \\
\text { proliferative } \\
\text { signaling, } \\
\text { Activating invasion } \\
\text { \& metastasis }\end{array}$ & $\begin{array}{l}\text { Cell survival, Cell } \\
\text { fate }\end{array}$ \\
\hline & $\begin{array}{c}\text { Anticancer/metastatic/ } \\
\text { proliferative/migratory/clonogeni } \\
\text { [643] }\end{array}$ & iic Metastasis & $\begin{array}{l}\text { Activating invasion } \\
\& \text { metastasis }\end{array}$ & Cell fate \\
\hline $\begin{array}{c}\text { MCF7 and } \\
\text { MDA-MB231 } \\
\text { SDG and ASECO * }\end{array}$ & $\downarrow$ Growth [653] & Proliferation & $\begin{array}{l}\text { Sustaining } \\
\text { proliferative } \\
\text { signaling } \\
\end{array}$ & Cell survival \\
\hline $\begin{array}{l}\mathrm{ER}+\mathrm{BC}(\mathrm{XM}) \\
\text { ENL and ED * }\end{array}$ & $\downarrow$ Angiogenesis [451] & Angiogenesis & $\begin{array}{c}\text { Inducing } \\
\text { angiogenesis }\end{array}$ & Cell survival \\
\hline $\begin{array}{l}\text { WPMY-1 } \\
\text { ENL * }\end{array}$ & $\begin{array}{l}\downarrow \text { proliferation, arrested cell } \\
\text { cycle }\left(G_{0} / G_{1}\right)[651]\end{array}$ & Proliferation & $\begin{array}{l}\text { Sustaining } \\
\text { proliferative } \\
\text { signaling }\end{array}$ & Cell survival \\
\hline $\begin{array}{l}\text { Rat model }(\mathrm{PH}) \\
\mathrm{SDG}^{*}\end{array}$ & $\begin{array}{c}\downarrow \text { Prostate enlargement, \# } \\
\text { papillary projections, } \\
\text { thickness of cell layers [651] }\end{array}$ & Proliferation & $\begin{array}{l}\text { Sustaining } \\
\text { proliferative } \\
\text { signaling }\end{array}$ & Cell survival \\
\hline \multirow{3}{*}{$\begin{array}{l}\text { WPE1-NA22, } \\
\text { WPE1-NB14, } \\
\text { WPE1-NB11, } \\
\text { WPE1-NB26 and } \\
\text { LNCaP } \\
\text { ENL * }\end{array}$} & $\begin{array}{c}\downarrow \text { Metabolic } \\
\text { activity, } \uparrow \text { doubling time [593] }\end{array}$ & $\begin{array}{l}\text { Proliferation, Stress } \\
\text { chemistry, Oxidation }\end{array}$ & $\begin{array}{c}\text { Sustaining } \\
\text { proliferative } \\
\text { signaling, } \\
\text { Deregulated } \\
\text { cellular energetics, } \\
\text { Evading growth } \\
\text { suppressors }\end{array}$ & $\begin{array}{l}\text { Cell survival, Cell } \\
\text { fate }\end{array}$ \\
\hline & Modulated cell cycle [593] & $\begin{array}{l}\text { Proliferation, } \\
\text { Immortality }\end{array}$ & $\begin{array}{l}\text { Evading growth } \\
\text { suppressors, } \\
\text { Sustaining } \\
\text { proliferative } \\
\text { signaling }\end{array}$ & $\begin{array}{l}\text { Cell survival, } \\
\text { Genome } \\
\text { maintenance }\end{array}$ \\
\hline & $\uparrow$ Apoptosis [593] & $\begin{array}{l}\text { Immortality, } \\
\text { Apoptosis }\end{array}$ & $\begin{array}{c}\text { Sustaining } \\
\text { proliferative } \\
\text { signaling, Resisting } \\
\text { cell death }\end{array}$ & Cell survival \\
\hline
\end{tabular}


Table 2. Cont

\begin{tabular}{|c|c|c|c|c|}
\hline $\begin{array}{l}\text { Experimental System } \\
\text { and Lignan * }\end{array}$ & $\begin{array}{l}\text { Targets: Molecules } \\
\text { (Protein/Gene) }\end{array}$ & Block's Model & $\begin{array}{c}\text { Hanahan and } \\
\text { Weinberg's Model }\end{array}$ & $\begin{array}{l}\text { Vogelstein et al., } \\
\text { Model }\end{array}$ \\
\hline \multirow{4}{*}{$\begin{array}{l}\text { LNCaP } \\
\text { ENL* }\end{array}$} & $\begin{array}{l}\uparrow \text { Sub-G0 and S, } \downarrow \text { G0/G1, } \\
\downarrow G 2 / \mathrm{M} \text { cell cycle [335] }\end{array}$ & $\begin{array}{l}\text { Proliferation, } \\
\text { Immortality }\end{array}$ & $\begin{array}{c}\text { Sustaining } \\
\text { proliferative } \\
\text { signaling, Evading } \\
\text { growth } \\
\text { suppressors }\end{array}$ & $\begin{array}{l}\text { Cell survival, Cell } \\
\text { fate }\end{array}$ \\
\hline & $\begin{array}{c}\downarrow \text { Cell density, } \downarrow \text { metabolic } \\
\text { activity, } \downarrow \text { PSA, } \uparrow \text { apoptosis } \\
{[335]}\end{array}$ & $\begin{array}{l}\text { Proliferation, } \\
\text { Apoptosis }\end{array}$ & $\begin{array}{c}\text { Sustaining } \\
\text { proliferative } \\
\text { signaling, Resisting } \\
\text { cell death, } \\
\text { Deregulated } \\
\text { cellular energetics }\end{array}$ & $\begin{array}{l}\text { Cell survival, Cell } \\
\text { fate }\end{array}$ \\
\hline & $\begin{array}{c}\uparrow \text { Apoptosis with anticancer } \\
\text { agents [335] }\end{array}$ & Apoptosis & Resisting cell death & Cell survival \\
\hline & $\begin{array}{l}\downarrow \text { Mitochondrial membrane } \\
\text { potential [634] }\end{array}$ & $\begin{array}{c}\text { Treatment resistance, } \\
\text { Stress chemistry, } \\
\text { Glycemia, Oxidation, } \\
\text { Proliferation, } \\
\text { Apoptosis }\end{array}$ & $\begin{array}{l}\text { Deregulated } \\
\text { cellular energetics }\end{array}$ & Cell survival \\
\hline \multirow[t]{2}{*}{$\begin{array}{l}\text { LNCaP } \\
\text { MAT * }^{*}\end{array}$} & $\begin{array}{c}\text { Death receptor sensitizer } \\
\text { (sensitizes TRAIL-induced } \\
\text { apoptosis) [629] }\end{array}$ & $\begin{array}{l}\text { Proliferation, } \\
\text { Apoptosis }\end{array}$ & $\begin{array}{c}\text { Sustaining } \\
\text { proliferative } \\
\text { signaling, Evading } \\
\text { growth } \\
\text { suppressors, } \\
\text { Resisting cell death }\end{array}$ & $\begin{array}{l}\text { Cell survival, Cell } \\
\text { fate }\end{array}$ \\
\hline & $\begin{array}{c}\uparrow \text { TRAIL-induced } \\
\text { mitochondrial } \\
\text { depolarization [629] }\end{array}$ & $\begin{array}{l}\text { Proliferation, } \\
\text { Apoptosis }\end{array}$ & $\begin{array}{l}\text { Resisting cell death, } \\
\text { Deregulated } \\
\text { cellular energetics }\end{array}$ & Cell survival \\
\hline \multirow[t]{2}{*}{$\begin{array}{l}\text { PC3 } \\
\text { ENL * }\end{array}$} & $\begin{array}{c}\downarrow \text { IGF- } 1 \text { induced proliferation, } \\
\downarrow \text { cell cycle arrest (G0/G1) } \\
{[618]}\end{array}$ & Proliferation & $\begin{array}{c}\text { Sustaining } \\
\text { proliferative } \\
\text { signaling, Evading } \\
\text { growth } \\
\text { suppressors }\end{array}$ & Cell survival \\
\hline & $\begin{array}{l}\downarrow \text { IGF-1 induced migration } \\
{[618]}\end{array}$ & Metastasis & $\begin{array}{l}\text { Activating invasion } \\
\text { \& metastasis }\end{array}$ & $\begin{array}{l}\text { Cell survival, Cell } \\
\text { fate }\end{array}$ \\
\hline \multirow[b]{2}{*}{$\begin{array}{l}\text { A549 and H60 } \\
\text { ENL * }\end{array}$} & $\downarrow$ Migration, invasion [628] & Metastasis & $\begin{array}{l}\text { Activating invasion } \\
\quad \& \text { metastasis }\end{array}$ & Cell fate \\
\hline & $\downarrow$ Density F-actin fibers [628] & $\begin{array}{l}\text { Metastasis, } \\
\text { Proliferation }\end{array}$ & $\begin{array}{c}\text { Activating invasion } \\
\text { \& metastasis, } \\
\text { Sustaining } \\
\text { proliferative } \\
\text { signaling }\end{array}$ & $\begin{array}{l}\text { Cell survival, Cell } \\
\text { fate }\end{array}$ \\
\hline $\begin{array}{c}\text { YAMC } \\
\text { ENL and ED * }\end{array}$ & $\begin{array}{c}\downarrow \text { Cell growth, } \uparrow \text { apoptosis } \\
{[586]}\end{array}$ & $\begin{array}{l}\text { Proliferation, } \\
\text { Apoptosis }\end{array}$ & $\begin{array}{l}\text { Resisting cell death, } \\
\text { Sustaining } \\
\text { proliferative } \\
\text { signaling, Evading } \\
\text { growth } \\
\text { suppressors }\end{array}$ & Cell survival \\
\hline $\begin{array}{c}\text { MG-63 } \\
\text { ENL and ED * }\end{array}$ & $\begin{array}{c}\text { Biphasic }(\downarrow \uparrow) \text { - cell viability, } \\
\text { ALP activity [650] }\end{array}$ & Proliferation & $\begin{array}{l}\text { Sustaining } \\
\text { proliferative } \\
\text { signaling }\end{array}$ & $\begin{array}{l}\text { Cell survival, Cell } \\
\text { fate }\end{array}$ \\
\hline $\begin{array}{l}\text { Mouse model } \\
\text { ENL * }\end{array}$ & $\begin{array}{c}\downarrow \text { Estradiol-induced } \\
\text { endothelial cell infiltration } \\
{[331]}\end{array}$ & Metastasis & $\begin{array}{l}\text { Activating invasion } \\
\text { \& metastasis }\end{array}$ & $\begin{array}{l}\text { Cell survival, Cell } \\
\text { fate }\end{array}$ \\
\hline $\begin{array}{l}\text { Colo201 } \\
\text { ENL * }\end{array}$ & $\begin{array}{l}\uparrow \text { Apoptosis (sub-G1 } \\
\text { cells), } \uparrow \text { cell viability [22] }\end{array}$ & $\begin{array}{l}\text { Proliferation, } \\
\text { Apoptosis }\end{array}$ & $\begin{array}{c}\text { Sustaining } \\
\text { proliferative } \\
\text { signaling, Evading } \\
\text { growth } \\
\text { suppressors, } \\
\text { Resisting cell death }\end{array}$ & Cell survival \\
\hline
\end{tabular}


Table 2. Cont

\begin{tabular}{|c|c|c|c|c|}
\hline $\begin{array}{l}\text { Experimental System } \\
\text { and Lignan * }\end{array}$ & $\begin{array}{l}\text { Targets: Molecules } \\
\text { (Protein/Gene) }\end{array}$ & Block's Model & $\begin{array}{c}\text { Hanahan and } \\
\text { Weinberg's Model }\end{array}$ & $\begin{array}{c}\text { Vogelstein et al., } \\
\text { Model }\end{array}$ \\
\hline \multirow[t]{2}{*}{$\begin{array}{l}\text { CC cells } \\
\text { ENL * }\end{array}$} & $\begin{array}{c}\uparrow \text { Cell death, } \downarrow \text { metabolic } \\
\text { activity in p53+ [588] }\end{array}$ & $\begin{array}{c}\text { Immortality, } \\
\text { Proliferation, } \\
\text { Treatment resistance, } \\
\text { Glycemia, Apoptosis }\end{array}$ & $\begin{array}{l}\text { Evading growth } \\
\text { suppressors, } \\
\text { Resisting cell death, } \\
\text { Deregulated } \\
\text { cellular energetics }\end{array}$ & $\begin{array}{l}\text { Cell survival, } \\
\text { Genome } \\
\text { maintenance }\end{array}$ \\
\hline & $\uparrow$ Apoptosis (Hela) [588] & Apoptosis & Resisting cell death & Cell survival \\
\hline $\begin{array}{c}\text { CC cells } \\
\text { ENL and ED * }\end{array}$ & $\downarrow$ Cell survival [588] & $\begin{array}{l}\text { Immortality, } \\
\text { Proliferation, } \\
\text { Apoptosis }\end{array}$ & $\begin{array}{c}\text { Sustaining } \\
\text { proliferative } \\
\text { signaling, Evading } \\
\text { growth } \\
\text { suppressors }\end{array}$ & $\begin{array}{l}\text { Cell survival, } \\
\text { Genome } \\
\text { maintenance }\end{array}$ \\
\hline $\begin{array}{l}\text { TR C33-A (CC) } \\
\text { ENL and ED * }\end{array}$ & $\begin{array}{l}\downarrow \text { Promoter activity } \\
\text { (Episomal, HPV } \\
\text { oncoproteins) [588] }\end{array}$ & Proliferation & $\begin{array}{c}\text { Sustaining } \\
\text { proliferative } \\
\text { signaling, Evading } \\
\text { growth } \\
\text { suppressors }\end{array}$ & Cell survival \\
\hline \multirow{2}{*}{$\begin{array}{l}\text { Hela } \\
\text { ENL * }\end{array}$} & $\uparrow$ p53 activity [588] & $\begin{array}{l}\text { Immortality, } \\
\text { Proliferation }\end{array}$ & $\begin{array}{l}\text { Evading growth } \\
\text { suppressors }\end{array}$ & $\begin{array}{l}\text { Cell survival, } \\
\text { Genome } \\
\text { maintenance }\end{array}$ \\
\hline & $\begin{array}{l}\text { No DNA-breaks } \\
\text { (genotoxicity) [588] }\end{array}$ & $\begin{array}{l}\text { Proliferation, } \\
\text { Apoptosis }\end{array}$ & $\begin{array}{l}\text { Resisting cell death, } \\
\text { Evading growth } \\
\text { suppressors }\end{array}$ & Cell survival \\
\hline $\begin{array}{l}\text { Hela/CaSki } \\
\text { ENL * }\end{array}$ & $\begin{array}{c}\uparrow \text { Apoptosis (Caspase 9, } \\
\text { Caspase 3) [588] }\end{array}$ & $\begin{array}{l}\text { Proliferation, } \\
\text { Apoptosis }\end{array}$ & Resisting cell death & Cell survival \\
\hline $\begin{array}{l}\text { CaSki } \\
\text { ED }^{*}\end{array}$ & $\uparrow$ Caspase 3 activity [588] & $\begin{array}{l}\text { Proliferation, } \\
\text { Apoptosis }\end{array}$ & Resisting cell death & Cell survival \\
\hline
\end{tabular}

${ }^{1}$ Note: Processors may include anything other than an individual protein/gene target expression such as cell cycle, invasion, motility, metastases, cell viability, apoptosis, cytoskeletal dynamics, ATP levels, metabolic rates, oxygen consumption, target activity, etc. Each molecule or processor can be related to multiple pathways and hallmarks indicated in the models, and therefore what is listed are some selected examples. The different types of lignans are indicated with an asteric $\left({ }^{*}\right)$; e.g., Lignan*. Lower case (simple) " $p$ " in certain instances denotes "phosphorylated" protein. Refer to abbreviations.

\section{Final Remarks}

Cancer remains a significant unmet medical need despite the extensive research into possible pharmaceutical solutions to tackle the various cancer phenotypes. Unfortunately, cancer will continue to be an important cause of morbidity and mortality in the near future as we witness increasing urbanization, increasing life expectancy, changing lifestyle, globalization, and changing environmental factors [4,654-658]. To address this global health dilemma, we may need to adopt a "broad-spectrum therapeutic approach" into our chemopreventive and therapeutic plans of cancer mitigation. Such a trend is already being observed as the 2012 U.S. National Health Interview Survey (NHIS) reported over $30 \%$ of adults and $12 \%$ of children used atypical approaches to health care [48]. The application of plant-derived bioactives or phytochemicals for disease prevention and treatment continues to gain attention as a desired approach for preventing or delaying disease [91]. Both human and preclinical studies suggest synergism of polyphenols such as lignans with existing therapeutics and, therefore, represent possible candidates for chemoprevention or as combination treatments with standard therapies such as chemotherapy, radiotherapy, immunotherapy, and gene therapy [259]. The overall results seem promising, yet the clinical evidence remains inconclusive [326,477,659-662]. Adoption of dietary polyphenols, like flaxseed lignans, into a "broad-spectrum therapeutic approach" will require an interdisciplinary approach combining prospective cohort studies investigating lignan exposure $[326,477,481]$ with mechanistic studies to confirm the health benefits of flaxseed lignan interventions [4,654-658]. 


\section{Conclusions}

Dietary polyphenols represent a diverse array of chemical subgroups with evidence of variable efficacy in mitigating cancer risk and progression. Despite epidemiological support of possible benefit, these compounds lack general acceptance as therapeutic modalities in cancer treatment. This likely relates to an incomplete understanding of their mechanisms of action as well as a general lack of understanding of their absorption and pharmacokinetic characteristics resulting too often in exposure levels inadequate to address the disease process. Hence, an important purpose of this article was to review the scientific evidence of the role of flaxseed lignans in chemoprevention and on the growth, survival, and progression of malignant cells. This review consolidates years of unsystematic research with the flaxseed lignans and identifies lignans as having multiple targets and modes of action within the cancer phenotype. These multitargeted effects are broadly grouped as modulation of cell signaling and metabolism, cell growth and differentiation, cell motility and cytoskeletal dynamics, cell cycle, angiogenesis, and apoptosis. Such effects might explain the limited epidemiological evidence of lignan benefit in cancer, but a systematic approach, which includes lignan preclinical studies with translational relevance as well as clinical trials utilizing therapeutically relevant doses, will be needed to clarify their role in cancer. As other pharmaceuticals (e.g., the statin drugs) undergo repurposing to cancer treatment, a systematic investigation of polyphenolics such as the lignans might also harness their potential benefits towards chemoprevention and enhancement of patient longevity and quality of life.

Supplementary Materials: The following are available online at http://www.mdpi.com/1424-8247/12/2/68/s1, Figure S1: Flaxseed Lignan Secoisolariciresinol Oligomer Chemical Structure; Table S1: Various Metabolites of Enterodiol (ED) and Enterolactone (ENL) Detected in Different Species; Table S2: Clinical Studies on Flaxseed/Flaxseed Lignans Administration.

Author Contributions: Conceptualization, S.F.D.S.; Methodology and Graphics, S.F.D.S.; Validation, S.F.D.S. and J.A.; Formal Analysis, S.F.D.S.; Investigation, S.F.D.S.; Writing-Original Draft Preparation, S.F.D.S.; Writing-Review, Subsequent Drafts, and Editing, S.F.D.S. and J.A.; Visualization, S.F.D.S. and J.A.; Supervision, J.A.; Project Administration, J.A.; Funding Acquisition, J.A.

Funding: This review article received no external funding. The scholarships for Shanal Franklyn De Silva were provided by the University of Saskatchewan College of Pharmacy and Nutrition and College of Graduate and Postdoctoral Studies (Saskatoon, Saskatchewan).

Acknowledgments: University of Saskatchewan College of Pharmacy and Nutrition Graduate Program's Office, Past-Associate Dean Alfred Remillard and the Dean Kishor Wasan for their support in numerous ways including conference travel support for S.F.D.S.

Conflicts of Interest: The authors declare no conflict of interest. The funders had no role in the design of the study, in the collection, analyses or interpretation, in the writing of the manuscript, or in the decision to publish this review.

\section{Abbreviations}

$\begin{array}{ll}\text { Apc-Min } & \text { Mouse tumor model (intestinal and mammary) } \\ \text { AKT1 } & \text { AKT (RAC-alpha) serine/threonine kinase 1 } \\ \text { ASECO } & \text { Anhydro-secoisolariciresinol } \\ \text { Bax } & \text { Bcl-2-associated X protein } \\ \text { BC } & \text { Breast cancer } \\ \text { Biphasic } & \uparrow \text { lower/ } \downarrow \text { higher concentration } \\ \text { CC } & \text { Cervical Cancer } \\ \text { TR } & \text { Transfected } \\ \text { COC } & \text { Colon cancer } \\ \text { ALP } & \text { alkaline phosphatase } \\ \text { miR } & \text { micro RNA } \\ \text { ERK } & \text { Extracellular signal-regulated kinases } \\ \text { subG1 } & \text { DNA profile representing cells in the G1 stage of the cell cycle } \\ \text { F-actin } & \text { Filamentous actin } \\ \text { BIRC5 } & \text { Survivin } \\ \text { BRCA1 } & \text { breast cancer type 1 (BCT1) susceptibility protein }\end{array}$




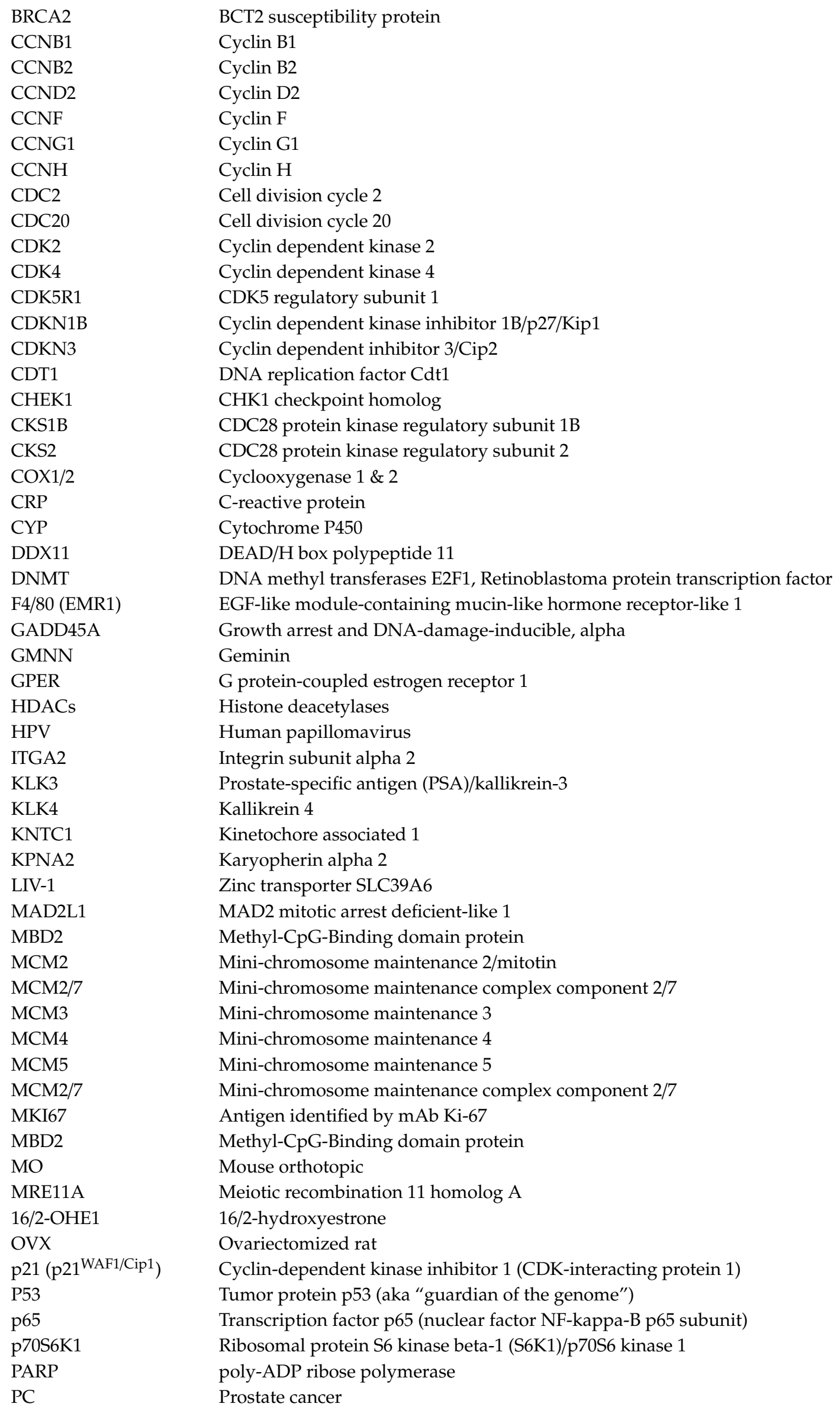




$\begin{array}{ll}\text { PCNA } & \text { Proliferating cell nuclear antigen } \\ \text { PDGF } & \text { Platelet-derived growth factor } \\ \text { PH } & \text { Prostatic hyperplasia } \\ \text { PIAS1 } & \text { E3 SUMO-protein ligase PIAS1 } \\ \text { PRKCD } & \text { Protein kinase C delta type } \\ \text { PRKCH } & \text { Protein kinase C eta type } \\ \text { Prostaglandin E2 } & \text { Dinoprostone } \\ \text { PS } & \text { Prostate Stromal } \\ \text { pS2 (TFF1) } & \text { Trefoil factor family 1 } \\ \text { RASSF1 } & \text { Ras association domain-containing protein 1 } \\ \text { RBL1 } & \text { Retinoblastoma-like 1/p107 } \\ \text { RPA3 } & \text { Replication protein A3 } \\ \text { SKP2 } & \text { S-phase kinase-associated protein } \\ \text { SLC43A1 } & \text { Large neutral amino acid transporter small subunit 3 } \\ \text { TPM1 } & \text { Tropomyosin alpha-1 } \\ \text { VEGFR } & \text { Vascular endothelial growth factor receptor } \\ \text { XM } & \text { Xenograft model } \\ \text { YAMC } & \text { Young adult mouse colon } \\ \text { ZIP2 } & \text { Zinc transporter SLC39A2 } \\ \text { ZnT-1 } & \text { Zinc transporter protein 1 }\end{array}$

\section{References}

1. Saarinen, N.M.; Tuominen, J.; Pylkkänen, L.; Santti, R. Assessment of Information to Substantiate a Health Claim on the Prevention of Prostate Cancer by Lignans. Nutrients 2010, 2, 99-115. [CrossRef]

2. Zhou, Y.; Zheng, J.; Li, Y.; Xu, D.P.; Li, S.; Chen, Y.M.; Li, H.B. Natural Polyphenols for Prevention and Treatment of Cancer. Nutrients 2016, 8, 515. [CrossRef]

3. Lee, J.; Khor, T.; Shu, L.; Su, Z.; Fuentes, F.; Kong, A. Dietary phytochemicals and cancer prevention: Nrf2 signaling, epigenetics, and cell death mechanisms in blocking cancer initiation and progression. Pharmacol. Ther. 2013, 137, 53-171. [CrossRef] [PubMed]

4. Surh, Y.J. Cancer chemoprevention with dietary phytochemicals. Nat. Rev. Cancer 2003, 3, 768-780. [CrossRef]

5. DeLuca, J.A.A.; Garcia-Villatoro, E.L.; Allred, C.D. Flaxseed Bioactive Compounds and Colorectal Cancer Prevention. Curr. Oncol. Rep. 2018, 20, 59. [CrossRef] [PubMed]

6. Kezimana, P.; Dmitriev, A.A.; Kudryavtseva, A.V.; Romanova, E.V.; Melnikova, N.V. Secoisolariciresinol Diglucoside of Flaxseed and Its Metabolites: Biosynthesis and Potential for Nutraceuticals. Front. Genet. 2018, 9, 641. [CrossRef] [PubMed]

7. Prasad, K. Flaxseed and cardiovascular health. J. Cardiovasc. Pharmacol. 2009, 54, 369-377. [CrossRef]

8. Calado, A.; Neves, P.M.; Santos, T.; Ravasco, P. The Effect of Flaxseed in Breast Cancer: A Literature Review. Front. Nutr. 2018, 5, 4. [CrossRef]

9. Zhang, W.; Wang, X.; Liu, Y.; Tian, H.; Flickinger, B.; Empie, M.W.; Sun, S.Z. Dietary flaxseed lignan extract lowers plasma cholesterol and glucose concentrations in hypercholesterolaemic subjects. Br. J. Nutr. 2008, 99, 1301-1309. [CrossRef]

10. Zanwar, A.A.; Hegde, M.V.; Rojatkar, S.R.; Sonawane, K.B.; Rajamohanan, P.R.; Bodhankar, S.L. Isolation, characterization and antihyperlipidemic activity of secoisolariciresinol diglucoside in poloxamer-407-induced experimental hyperlipidemia. Pharm. Biol. 2014, 52, 1094-1103. [CrossRef]

11. Thompson, L.U.; Rickard, S.E.; Orcheson, L.J.; Seidl, M.M. Flaxseed and its lignan and oil components reduce mammary tumor growth at a late stage of carcinogenesis. Carcinogenesis 1996, 17, 1373-1376. [CrossRef]

12. Pilar, B.; Gullich, A.; Oliveira, P.; Stroher, D.; Piccoli, J.; Manfredini, V. Protective Role of Flaxseed Oil and Flaxseed Lignan Secoisolariciresinol Diglucoside Against Oxidative Stress in Rats with Metabolic Syndrome. J. Food Sci. 2017, 82, 3029-3036. [CrossRef]

13. Wang, L.; Chen, J.; Thompson, L.U. The inhibitory effect of flaxseed on the growth and metastasis of estrogen receptor negative human breast cancer xenograftsis attributed to both its lignan and oil components. Int. J. Cancer 2005, 116, 793-798. [CrossRef] [PubMed] 
14. Power, K.A.; Thompson, L.U. Can the combination of flaxseed and its lignans with soy and its isoflavones reduce the growth stimulatory effect of soy and its isoflavones on established breast cancer? Mol. Nutr. Food Res. 2007, 51, 845-856. [CrossRef]

15. Goyal, A.; Sharma, V.; Upadhyay, N.; Gill, S.; Sihag, M. Flax and flaxseed oil: An ancient medicine \& modern functional food. J. Food Sci. Technol. 2014, 51, 1633-1653. [CrossRef]

16. Kajla, P.; Sharma, A.; Sood, D.R. Flaxseed-a potential functional food source. J. Food Sci. Technol. 2015, 52, 1857-1871. [CrossRef]

17. Rodriguez-Leyva, D.; Dupasquier, C.M.C.; McCullough, R.; Pierce, G.N. The cardiovascular effects of flaxseed and its omega-3 fatty acid, alpha-linolenic acid. Can. J. Cardiol. 2010, 26, 489-496. [CrossRef]

18. Shirvani, H.; Rahmati-Ahmadabad, S. Irisin interaction with adipose tissue secretions by exercise training and flaxseed oil supplement. Lipids Health Disease 2019, 18, 15. [CrossRef]

19. Bassett, C.M.; Rodriguez-Leyva, D.; Pierce, G.N. Experimental and clinical research findings on the cardiovascular benefits of consuming flaxseed. Appl. Physiol. Nutr. Metab. 2009, 34, 965-974. [CrossRef]

20. Gillingham, L.G.; Gustafson, J.A.; Han, S.-Y.; Jassal, D.S.; Jones, P.J.H. High-oleic rapeseed (canola) and flaxseed oils modulate serum lipids and inflammatory biomarkers in hypercholesterolaemic subjects. $\mathrm{Br}$. J. Nutr. 2010, 105, 417-427. [CrossRef] [PubMed]

21. Mason, J.K.; Thompson, L.U. Flaxseed and its lignan and oil components: Can they play a role in reducing the risk of and improving the treatment of breast cancer? Appl. Physiol. Nutr. Metab. 2014, 39, 663-678. [CrossRef] [PubMed]

22. Danbara, N.; Yuri, T.; Tsujita-Kyutoku, M.; Tsukamoto, R.; Uehara, N.; Tsubura, A. Enterolactone Induces Apoptosis and Inhibits Growth of Colo 201 Human Colon Cancer Cells both In Vitro and In Vivo. Anticancer Res. 2005, 25, 2269-2276.

23. Kuijsten, A.; Arts, I.C.W.; Hollman, P.C.H.; van't Veer, P.; Kampman, E. Plasma Enterolignans Are Associated with Lower Colorectal Adenoma Risk. Cancer Epidemiol. Biomark. Prev. 2006, 15, 1132-1136. [CrossRef] [PubMed]

24. Zanwar, A.A.; Hegde, M.V.; Bodhankar, S.L. Chapter 71-Flax Lignan in the Prevention of Atherosclerotic Cardiovascular Diseases. In Polyphenols in Human Health and Disease; Watson, R.R., Preedy, V.R., Zibadi, S., Eds.; Academic Press: San Diego, CA, USA, 2014; pp. 915-921. [CrossRef]

25. Adolphe, J.L.; Whiting, S.J.; Juurlink, B.H.J.; Thorpe, L.U.; Alcorn, J. Health effects with consumption of the flax lignan secoisolariciresinol diglucoside. Br. J. Nutr. 2009, 103, 929-938. [CrossRef]

26. Puukila, S.; Fernandes, R.O.; Turck, P.; Carraro, C.C.; Bonetto, J.H.P.; de Lima-Seolin, B.G.; da Rosa Araujo, A.S.; Bello-Klein, A.; Boreham, D.; Khaper, N. Secoisolariciresinol diglucoside attenuates cardiac hypertrophy and oxidative stress in monocrotaline-induced right heart dysfunction. Mol. Cell Biochem. 2017, 432, 33-39. [CrossRef]

27. Prasad, K.; Jadhav, A. Prevention and treatment of atherosclerosis with flaxseed-derived compound secoisolariciresinol diglucoside. Curr. Pharm. Des. 2016, 22, 214-220. [CrossRef]

28. Imran, M.; Ahmad, N.; Anjum, F.M.; Khan, M.K.; Mushtaq, Z.; Nadeem, M.; Hussain, S. Potential protective properties of flax lignan secoisolariciresinol diglucoside. Nutr. J. 2015, 14, 71. [CrossRef]

29. Jenab, M.; Thompson, L.U. The influence of flaxseed and lignans on colon carcinogenesis and beta-glucuronidase activity. Carcinogenesis 1996, 17, 1343-1348. [CrossRef]

30. Jenab, M.; Rickard, S.E.; Orcheson, L.J.; Thompson, L.U. Flaxseed and lignans increase cecal beta-glucuronidase activity in rats. Nutr. Cancer 1999, 33, 154-158. [CrossRef]

31. Serraino, M.; Thompson, L.U. Flaxseed supplementation and early markers of colon carcinogenesis. Cancer Lett. 1992, 63, 159-165. [CrossRef]

32. Li, D.; Yee, J.A.; Thompson, L.U.; Yan, L. Dietary supplementation with secoisolariciresinol diglycoside (SDG) reduces experimental metastasis of melanoma cells in mice. Cancer Lett. 1999, 142, 91-96. [CrossRef]

33. Truan, J.S.; Chen, J.M.; Thompson, L.U. Comparative effects of sesame seed lignan and flaxseed lignan in reducing the growth of human breast tumors (MCF-7) at high levels of circulating estrogen in athymic mice. Nutr. Cancer 2012, 64, 65-71. [CrossRef]

34. Wiggins, A.K.; Mason, J.K.; Thompson, L.U. Beneficial Influence of Diets Enriched with Flaxseed and Flaxseed Oil on Cancer. In Cancer Chemoprevention and Treatment by Diet Therapy; Cho, W.C.S., Ed.; Springer: Dordrecht, The Netherlands, 2013; pp. 55-89. [CrossRef] 
35. Rhee, Y.; Brunt, A. Flaxseed supplementation improved insulin resistance in obese glucose intolerant people: A randomized crossover design. Nutr. J. 2011, 10, 44. [CrossRef]

36. Zhu, Y.; Kawaguchi, K.; Kiyama, R. Differential and directional estrogenic signaling pathways induced by enterolignans and their precursors. PLoS ONE 2017, 12, e0171390. [CrossRef]

37. Krajčová, A.; Schulzová, V.; Hajšlová, J.; Bjelková, M. Lignans in Flaxseed Lignans in Flaxseed. Czech J. Food Sci. 2009, 27, S252-S255. [CrossRef]

38. Touré, A.; Xueming, X. Flaxseed Lignans: Source, Biosynthesis, Metabolism, Antioxidant Activity, Bio-Active Components, and Health Benefits. Compr. Rev. Food Sci. Food Saf. 2010, 9, 261-269. [CrossRef]

39. Peterson, J.; Dwyer, J.; Adlercreutz, H.; Scalbert, A.; Jacques, P.; McCullough, M.L. Dietary lignans: Physiology and potential for cardiovascular disease risk reduction. Nutr. Rev. 2010, 68, 571-603. [CrossRef]

40. Bagniewska-Zadworna, A.; Barakat, A.; Lakomy, P.; Smolinski, D.J.; Zadworny, M. Lignin and lignans in plant defence: Insight from expression profiling of cinnamyl alcohol dehydrogenase genes during development and following fungal infection in Populus. Plant Sci. 2014, 229, 111-121. [CrossRef]

41. Zhu, H.-Y.; Li, M.-X.; Yang, D.-H.; Tao, Y.-L.; Zhang, Y.; Liu, S.-L. Biotransformation of the SDG in defatted flaxseed into END co-cultured by three single bacterial colonies. Process Biochem. 2014, 49, 19-24. [CrossRef]

42. Wang, L.Q.; Meselhy, M.R.; Li, Y.; Qin, G.W.; Hattori, M. Human intestinal bacteria capable of transforming secoisolariciresinol diglucoside to mammalian lignans, enterodiol and enterolactone. Chem. Pharm. Bull. 2000, 48, 1606-1610. [CrossRef] [PubMed]

43. Bannwart, C.; Adlercreutz, H.; Wahala, K.; Brunow, G.; Hase, T. Detection and identification of the plant lignans lariciresinol, isolariciresinol and secoisolariciresinol in human urine. Clin. Chim. Acta 1989, 180, 293-301. [CrossRef]

44. Saarinen, N.M.; Warri, A.; Makela, S.I.; Eckerman, C.; Reunanen, M.; Ahotupa, M.; Salmi, S.M.; Franke, A.A.; Kangas, L.; Santti, R. Hydroxymatairesinol, a novel enterolactone precursor with antitumor properties from coniferous tree (Picea abies). Nutr. Cancer 2000, 36, 207-216. [CrossRef] [PubMed]

45. Borriello, S.P.; Setchell, K.D.; Axelson, M.; Lawson, A.M. Production and metabolism of lignans by the human faecal flora. J. Appl. Bacteriol. 1985, 58, 37-43. [CrossRef]

46. Heinonen, S.; Nurmi, T.; Liukkonen, K.; Poutanen, K.; Wahala, K.; Deyama, T.; Nishibe, S.; Adlercreutz, H. In vitro metabolism of plant lignans: New precursors of mammalian lignans enterolactone and enterodiol. J. Agric. Food Chem. 2001, 49, 3178-3186. [CrossRef]

47. Jin, J.-S.; Hattori, M. A new mammalian lignan precursor, asarinin. Food Chem. 2011, 124, 895-899. [CrossRef]

48. US-Department-of-Health-and-Human-Services. Complementary, Alternative, or Integrative Health: What's in a Name? Available online: https://nccih.nih.gov/health/integrative-health (accessed on 30 March 2019).

49. Zhang, J.; Onakpoya, I.J.; Posadzki, P.; Eddouks, M. The safety of herbal medicine: From prejudice to evidence. Evid. Based Complement. Alternat. Med. 2015, 2015, 316706. [CrossRef] [PubMed]

50. Ekor, M. The growing use of herbal medicines: Issues relating to adverse reactions and challenges in monitoring safety. Front. Pharmacol. 2014, 4, 177. [CrossRef]

51. Raynor, D.K.; Dickinson, R.; Knapp, P.; Long, A.F.; Nicolson, D.J. Buyer beware? Does the information provided with herbal products available over the counter enable safe use? BMC Med. 2011, 9, 94. [CrossRef]

52. Pawar, R.S.; Grundel, E. Overview of regulation of dietary supplements in the USA and issues of adulteration with phenethylamines (PEAs). Drug Test. Anal. 2017, 9, 500-517. [CrossRef]

53. Laeeque, H.; Boon, H.; Kachan, N.; Cohen, J.C.; D’Cruz, J. The Canadian Natural Health Products (NHP) regulations: Industry perceptions and compliance factors. BMC Health Serv. Res. 2006, 6, 63. [CrossRef]

54. Tamayo, C.; Ann, H. Canada's Natural Health Products: A Regulatory Overview. Pharm. Regul. Aff. Open Access 2016, 5, 1.

55. Di, Y. Flaxseed Lignan Supplementation as Possible Adjuvant Therapy for Prostate and Breast Cancer. Ph.D. Thesis, University of Saskatchewan, Saskatoon, SK, Canada, 2017.

56. Weeks, C. Health Canada Rules Ask for Science behind Natural Health Products' Claims. Available online: https:/www.theglobeandmail.com/life/health-and-fitness/health/health-canada-rulesask-for-science-behind-natural-products-claims-health/article33287337/ (accessed on 12 December 2017).

57. Wilson, V.L. Carcinogenesis as the Sum of Its Parts. Disrupt. Sci. Technol. 2012, 1, 110-115. [CrossRef]

58. Block, K.I.; Gyllenhaal, C.; Lowe, L.; Amedei, A.; Amin, A.R.; Amin, A.; Aquilano, K.; Arbiser, J.; Arreola, A.; Arzumanyan, A.; et al. Designing a broad-spectrum integrative approach for cancer prevention and treatment. Semin. Cancer Biol. 2015, 35, S276-S304. [CrossRef] 
59. Block, K.I.; Gyllenhaal, C.; Lowe, L.; Amedei, A.; Amin, A.R.; Amin, A.; Aquilano, K.; Arbiser, J.; Arreola, A.; Arzumanyan, A.; et al. A Broad-Spectrum Integrative Design for Cancer Prevention and Therapy. Semin. Cancer Biol. 2015, 35, S276-S304. [CrossRef]

60. Huerta, E.; Grey, N. Cancer control opportunities in low- and middle-income countries. CA Cancer J. Clin. 2007, 57, 72-74. [CrossRef]

61. Ginsburg, O.M. Breast and cervical cancer control in low and middle-income countries: Human rights meet sound health policy. J. Cancer Policy 2013, 1, e35-e41. [CrossRef]

62. Hanahan, D.; Weinberg, R.A. Hallmarks of Cancer: The Next Generation. Cell 2011, 144, 646-674. [CrossRef] [PubMed]

63. Hanahan, D.; Weinberg, R.A. The Hallmarks of Cancer. Cell 2000, 100, 57-70. [CrossRef]

64. Steward, W.P.; Brown, K. Cancer chemoprevention: A rapidly evolving field. Br. J. Cancer 2013, 109, 1-7. [CrossRef]

65. Mocanu, M.M.; Nagy, P.; Szollosi, J. Chemoprevention of Breast Cancer by Dietary Polyphenols. Molecules 2015, 20, 22578-22620. [CrossRef]

66. Othman, N.H. Honey and cancer: Sustainable inverse relationship particularly for developing nations-a review. Evid. Based Complement. Alternat. Med. 2012, 2012, 410406. [CrossRef]

67. Kotecha, R.; Takami, A.; Espinoza, J.L. Dietary phytochemicals and cancer chemoprevention: A review of the clinical evidence. Oncotarget 2016, 7, 52517-52529. [CrossRef] [PubMed]

68. Pitot, H.C. The molecular biology of carcinogenesis. Cancer 1993, 72, 962-970. [CrossRef]

69. Fajardo, A.M.; Piazza, G.A. Chemoprevention in gastrointestinal physiology and disease. Anti-inflammatory approaches for colorectal cancer chemoprevention. Am. J. Physiol. Gastrointest. Liver Physiol. 2015, 309, G59-G70. [CrossRef] [PubMed]

70. Al Rabadi, L.; Bergan, R. A Way Forward for Cancer Chemoprevention: Think Local. Cancer Prev. Res. 2017, 10, 14-35. [CrossRef] [PubMed]

71. Todoric, J.; Antonucci, L.; Karin, M. Targeting Inflammation in Cancer Prevention and Therapy. Cancer Prev. Res. 2016, 9, 895-905. [CrossRef] [PubMed]

72. Siegel, R.L.; Miller, K.D.; Jemal, A. Cancer statistics, 2016. CA Cancer J. Clin. 2016, 66, 7-30. [CrossRef]

73. Grivennikov, S.I.; Greten, F.R.; Karin, M. Immunity, inflammation, and cancer. Cell 2010, 140, 883-899. [CrossRef] [PubMed]

74. Williams, C.S.; Mann, M.; DuBois, R.N. The role of cyclooxygenases in inflammation, cancer, and development. Oncogene 1999, 18, 7908-7916. [CrossRef]

75. Gurpinar, E.; Grizzle, W.E.; Piazza, G.A. NSAIDs inhibit tumorigenesis, but how? Clin. Cancer Res. 2014, 20, 1104-1113. [CrossRef]

76. Harris, R.E.; Beebe-Donk, J.; Doss, H.; Burr Doss, D. Aspirin, ibuprofen, and other non-steroidal anti-inflammatory drugs in cancer prevention: A critical review of non-selective COX-2 blockade (review). Oncol. Rep. 2005, 13, 559-583. [CrossRef]

77. Umamaheswaran, S.; Dasari, S.K.; Yang, P.; Lutgendorf, S.K.; Sood, A.K. Stress, inflammation, and eicosanoids: An emerging perspective. Cancer Metastasis. Rev. 2018, 37, 203-211. [CrossRef]

78. Aravindaram, K.; Yang, N.S. Anti-inflammatory plant natural products for cancer therapy. Planta Med. 2010, 76, 1103-1117. [CrossRef]

79. Tan, A.C.; Konczak, I.; Sze, D.M.; Ramzan, I. Molecular pathways for cancer chemoprevention by dietary phytochemicals. Nutr. Cancer 2011, 63, 495-505. [CrossRef]

80. Ramos, S. Effects of dietary flavonoids on apoptotic pathways related to cancer chemoprevention. J. Nutr. Biochem. 2007, 18, 427-442. [CrossRef]

81. Institute-for-Work-and-Health-Toronto. Primary, Secondary and Tertiary Prevention. Available online: https://www.iwh.on.ca/what-researchers-mean-by/primary-secondary-and-tertiary-prevention (accessed on 30 March 2019).

82. Gapstur, S.M.; Drope, J.M.; Jacobs, E.J.; Teras, L.R.; McCullough, M.L.; Douglas, C.E.; Patel, A.V.; Wender, R.C.; Brawley, O.W. A blueprint for the primary prevention of cancer: Targeting established, modifiable risk factors. CA Cancer J. Clin. 2018, 68, 446-470. [CrossRef]

83. Blackburn, E.H. Highlighting the Science of Cancer Prevention. Cancer Prev. Res. 2010, 3, 393. [CrossRef]

84. Schoenberg, M.H. Physical Activity and Nutrition in Primary and Tertiary Prevention of Colorectal Cancer. Visc. Med. 2016, 32, 199-204. [CrossRef] 
85. Rock, C.L.; Yang, C.S.; Alberts, D.S.; Meyskens, F.L., Jr.; Mukhtar, H.; Cuzick, J.; Ramsey, S.D.; Lippman, S.M.; Kensler, T.W. Cancer Prevention: Obstacles, Challenges, and the Road Ahead. JNCI J. Natl. Cancer Inst. 2015, 108. [CrossRef]

86. Berrino, F. Life style prevention of cancer recurrence: The yin and the yang. Cancer Treat. Res. 2014, 159, 341-351. [CrossRef]

87. De Flora, S.; Izzotti, A.; D'Agostini, F.; Balansky, R.M.; Noonan, D.; Albini, A. Multiple points of intervention in the prevention of cancer and other mutation-related diseases. Mutat. Res. 2001, 480-481, 9-22. [CrossRef]

88. De Flora, S.; Ferguson, L.R. Overview of mechanisms of cancer chemopreventive agents. Mutat. Res. 2005, 591, 8-15. [CrossRef]

89. Sporn, M.B.; Dunlop, N.; Newton, D.; Smith, J. Prevention of chemical carcinogenesis by vitamin A and its synthetic analogs (retinoids). Feder. Proc. 1976, 35, 1332-1338.

90. Wattenberg, L.W. Inhibition of carcinogenesis by minor anutrient constituents of the diet. Proc. Nutr. Soc. 1990, 49, 173-183. [CrossRef] [PubMed]

91. Mehta, R.G.; Murillo, G.; Naithani, R.; Peng, X. Cancer Chemoprevention by Natural Products: How Far Have We Come? Pharm. Res. 2010, 27, 950-961. [CrossRef]

92. Amawi, H.; Ashby, C.R., Jr.; Tiwari, A.K. Cancer chemoprevention through dietary flavonoids: what's limiting? Chin. J. Cancer 2017, 36, 50. [CrossRef] [PubMed]

93. Benetou, V.; Lagiou, A.; Lagiou, P. Chemoprevention of cancer: Current evidence and future prospects. F1000Research 2015, 4, 916. [CrossRef]

94. Naomi, G.; Gad, R. Beyond aspirin-Cancer prevention with statins, metformin and bisphosphonates. Nat. Rev. Clin. Oncol. 2013, 10, 625. [CrossRef]

95. Bosland, M.C. Is There a Future for Chemoprevention of Prostate Cancer? Cancer Prev. Res. 2016, 9, 642-647. [CrossRef]

96. Kreuger, M.R.; Grootjans, S.; Biavatti, M.W.; Vandenabeele, P.; D’Herde, K. Sesquiterpene lactones as drugs with multiple targets in cancer treatment: Focus on parthenolide. Anticancer Drugs 2012, 23, 883-896. [CrossRef]

97. Cragg, G.M.; Grothaus, P.G.; Newman, D.J. Impact of natural products on developing new anti-cancer agents. Chem. Rev. 2009, 109, 3012-3043. [CrossRef] [PubMed]

98. Kingston, D.G. Modern natural products drug discovery and its relevance to biodiversity conservation. J. Nat. Prod. 2011, 74, 496-511. [CrossRef] [PubMed]

99. Abotaleb, M.; Samuel, S.M.; Varghese, E.; Varghese, S.; Kubatka, P.; Liskova, A.; Büsselberg, D. Flavonoids in Cancer and Apoptosis. Cancers 2018, 11, 28. [CrossRef]

100. Vue, B.; Zhang, S.; Chen, Q.H. Flavonoids with Therapeutic Potential in Prostate Cancer. Anticancer Agents Med. Chem. 2016, 16, 1205-1229. [CrossRef] [PubMed]

101. Han, D.; Tachibana, H.; Yamada, K. Inhibition of environmental estrogen-induced proliferation of human breast carcinoma MCF-7 cells by flavonoids. In Vitro Cell. Dev. Biol. Anim. 2001, 37, 275-282. [PubMed]

102. Yin, F.; Giuliano, A.E.; Van Herle, A.J. Signal pathways involved in apigenin inhibition of growth and induction of apoptosis of human anaplastic thyroid cancer cells (ARO). Anticancer Res. 1999, 19, 4297-4303.

103. Cho, H.J.; Suh, D.S.; Moon, S.H.; Song, Y.J.; Yoon, M.S.; Park, D.Y.; Choi, K.U.; Kim, Y.K.; Kim, K.H. Silibinin inhibits tumor growth through downregulation of extracellular signal-regulated kinase and Akt in vitro and in vivo in human ovarian cancer cells. J. Agric. Food Chem. 2013, 61, 4089-4096. [CrossRef]

104. Petrick, J.L.; Steck, S.E.; Bradshaw, P.T.; Trivers, K.F.; Abrahamson, P.E.; Engel, L.S.; He, K.; Chow, W.H.; Mayne, S.T.; Risch, H.A.; et al. Dietary intake of flavonoids and oesophageal and gastric cancer: Incidence and survival in the United States of America (USA). Br. J. Cancer 2015, 112, 1291-1300. [CrossRef]

105. Rossi, M.; Rosato, V.; Bosetti, C.; Lagiou, P.; Parpinel, M.; Bertuccio, P.; Negri, E.; La Vecchia, C. Flavonoids, proanthocyanidins, and the risk of stomach cancer. Cancer Causes Control. 2010, 21, 1597-1604. [CrossRef]

106. Zhou, Y. Vitexins, nature-derived lignan compounds, induce apoptosis and suppress tumor growth. Clin. Cancer Res. 2009, 15. [CrossRef]

107. Yatkin, E.; Polari, L.; Laajala, T.D.; Smeds, A.; Eckerman, C.; Holmbom, B.; Saarinen, N.M.; Aittokallio, T.; Mäkelä, S.I. Novel lignan and stilbenoid mixture shows anticarcinogenic efficacy in preclinical PC-3M-luc2 prostate cancer model. PLoS ONE 2014, 9, e93764. [CrossRef] [PubMed]

108. Yan, L.; Yee, J.A.; Li, D.; McGuire, M.H.; Thompson, L.U. Dietary flaxseed supplementation and experimental metastasis of melanoma cells in mice. Cancer Lett. 1998, 124, 181-186. [CrossRef] 
109. Westcott, N.D.; Muir, A.D. Flax seed lignan in disease prevention and health promotion. Phytochem. Rev. 2003, 2, 401-417. [CrossRef]

110. Boyland, E. Critical review of problems of chemotherapy. Proc. R. Soc. Med. 1963, 56, 640-642. [PubMed]

111. Nurgali, K.; Jagoe, R.T.; Abalo, R. Editorial: Adverse Effects of Cancer Chemotherapy: Anything New to Improve Tolerance and Reduce Sequelae? Front. Pharmacol. 2018, 9, 245. [CrossRef]

112. Block, K.I.; Block, P.B.; Gyllenhaal, C. Integrative Therapies in Cancer:Modulating a Broad Spectrum of Targets for Cancer Management. Integr. Cancer Ther. 2015, 14, 113-118. [CrossRef] [PubMed]

113. Marchand, L. Integrative and complementary therapies for patients with advanced cancer. Ann. Palliat. Med. 2014, 3, 160-171.

114. Academic Consortium for Integrative Medicine and, H. Definition of Integrative Medicine and Health. Available online: https://imconsortium.org/ (accessed on 30 March 2019).

115. Eran, B.-A.; Noah, S.; Ofer, L. Integrative Medicine for Female Patients with Gynecologic Cancer. J. Alternat. Complement. Med. 2018, 24, 881-889. [CrossRef]

116. E Alessandra Strada, R.K.P. Psychological, Rehabilitative, and Integrative Therapies for Cancer Pain-UpToDate. Available online: https:/www.uptodate.com/contents/psychological-rehabilitative-andintegrative-therapies-for-cancer-pain (accessed on 30 March 2019).

117. Redondo-Blanco, S.; Fernández, J.; Gutiérrez-del-Río, I.; Villar, C.J.; Lombó, F. New Insights toward Colorectal Cancer Chemotherapy Using Natural Bioactive Compounds. Front. Pharmacol. 2017, 8. [CrossRef]

118. Saxena, A.; Becker, D.; Preeshagul, I.; Lee, K.; Katz, E.; Levy, B. Therapeutic Effects of Repurposed Therapies in Non-Small Cell Lung Cancer: What Is Old Is New Again. Oncologist 2015, 20, 934-945. [CrossRef]

119. Farnsworth, N.R.; Akerele, O.; Bingel, A.S.; Soejarto, D.D.; Guo, Z. Medicinal plants in therapy. Bull. World Health Organ. 1985, 63, 965-981. [CrossRef]

120. Cragg, G.M.; Newman, D.J. Natural products: A continuing source of novel drug leads. Biochim. Biophys. Acta 2013, 1830, 3670-3695. [CrossRef]

121. Campbell, I.W. Metformin-Life begins at 50 A symposium held on the occasion of the 43rd Annual Meeting of the European Association for the Study of Diabetes, Amsterdam, The Netherlands, September 2007. Br. J. Diabetes Vasc. Disease 2007, 7, 247-252. [CrossRef]

122. Duthie, G.G.; Wood, A.D. Natural salicylates: Foods, functions and disease prevention. Food Funct. 2011, 2, 515-520. [CrossRef] [PubMed]

123. Newman, D.J.; Cragg, G.M. Natural products as sources of new drugs over the 30 years from 1981 to 2010. J. Nat. Prod. 2012, 75, 311-335. [CrossRef] [PubMed]

124. Dias, D.A.; Urban, S.; Roessner, U. A historical overview of natural products in drug discovery. Metabolites 2012, 2, 303-336. [CrossRef] [PubMed]

125. Gu, J.; Gui, Y.; Chen, L.; Yuan, G.; Lu, H.-Z.; Xu, X. Use of natural products as chemical library for drug discovery and network pharmacology. PLoS ONE 2013, 8, e62839. [CrossRef]

126. Fox, S.; Farr-Jones, S.; Sopchak, L.; Boggs, A.; Nicely, H.W.; Khoury, R.; Biros, M. High-throughput screening: Update on practices and success. J. Biomol. Screen. 2006, 11, 864-869. [CrossRef] [PubMed]

127. Katiyar, C.; Gupta, A.; Kanjilal, S.; Katiyar, S. Drug discovery from plant sources: An integrated approach. Ayu 2012, 33, 10-19. [CrossRef]

128. Jacobson, K.A. New paradigms in GPCR drug discovery. Biochem Pharmacol 2015, 98, 541-555. [CrossRef]

129. Pathania, S.; Ramakrishnan, S.M.; Bagler, G. Phytochemica: A platform to explore phytochemicals of medicinal plants. Database 2015, 2015. [CrossRef]

130. Tarkang, P.A.; Appiah-Opong, R.; Ofori, M.F.; Ayong, L.S.; Nyarko, A.K. Application of multi-target phytotherapeutic concept in malaria drug discovery: A systems biology approach in biomarker identification. Biomark. Res. 2016, 4, 25. [CrossRef] [PubMed]

131. Bhanot, A.; Sharma, R.; Noolvi, M.N. Natural sources as potential anti-cancer agents: A review. Int. J. Phytomed. 2011, 3, 18.

132. Willett, W.C. Diet and Cancer. Oncol. 2000, 5, 393-404. [CrossRef]

133. Li, M.; Cima, M.J.; Milner, D.A., Jr. If It's Not One Thing, It's Another: An Inverse Relationship of Malignancy and Atherosclerotic Disease. PLoS ONE 2015, 10, e0126855. [CrossRef]

134. Doll, R.; Peto, R. The causes of cancer: Quantitative estimates of avoidable risks of cancer in the United States today. JNCI J. Natl. Cancer Inst. 1981, 66, 1192-1308. [CrossRef] 
135. Cojocneanu Petric, R.; Braicu, C.; Raduly, L.; Zanoaga, O.; Dragos, N.; Monroig, P.; Dumitrascu, D.; Berindan-Neagoe, I. Phytochemicals modulate carcinogenic signaling pathways in breast and hormone-related cancers. Oncol. Targets Ther. 2015, 8, 2053-2066. [CrossRef]

136. Simonsen, H.T.; Drew, D.P.; Lunde, C. Perspectives on Using Physcomitrella Patens as an Alternative Production Platform for Thapsigargin and Other Terpenoid Drug Candidates. Perspect. Med. Chem. 2009, 3, 1-6. [CrossRef]

137. Lampe, J.W.; Chang, J.L. Interindividual differences in phytochemical metabolism and disposition. Semin. Cancer Biol. 2007, 17, 347-353. [CrossRef]

138. Adlercreutz, H. Lignans and human health. Crit. Rev. Clin. Lab. Sci. 2007, 44, 483-525. [CrossRef] [PubMed]

139. Fantini, M.; Benvenuto, M.; Masuelli, L.; Frajese, G.V.; Tresoldi, I.; Modesti, A.; Bei, R. In vitro and in vivo antitumoral effects of combinations of polyphenols, or polyphenols and anticancer drugs: Perspectives on cancer treatment. Int. J. Mol. Sci. 2015, 16, 9236-9282. [CrossRef]

140. Li, A.N.; Li, S.; Zhang, Y.J.; Xu, X.R.; Chen, Y.M.; Li, H.B. Resources and biological activities of natural polyphenols. Nutrients 2014, 6, 6020-6047. [CrossRef] [PubMed]

141. Lall, R.K.; Syed, D.N.; Adhami, V.M.; Khan, M.I.; Mukhtar, H. Dietary polyphenols in prevention and treatment of prostate cancer. Int. J. Mol. Sci. 2015, 16, 3350-3376. [CrossRef]

142. Manach, C.; Scalbert, A.; Morand, C.; Remesy, C.; Jimenez, L. Polyphenols: Food sources and bioavailability. Am. J. Clin. Nutr. 2004, 79, 727-747. [CrossRef] [PubMed]

143. Acosta-Estrada, B.A.; Gutierrez-Uribe, J.A.; Serna-Saldivar, S.O. Bound phenolics in foods, a review. Food Chem. 2014, 152, 46-55. [CrossRef] [PubMed]

144. Mosele, J.I.; Macia, A.; Motilva, M.J. Metabolic and Microbial Modulation of the Large Intestine Ecosystem by Non-Absorbed Diet Phenolic Compounds: A Review. Molecules 2015, 20, 17429-17468. [CrossRef]

145. Pandey, K.B.; Rizvi, S.I. Plant polyphenols as dietary antioxidants in human health and disease. Oxid. Med. Cell. Longev. 2009, 2, 270-278. [CrossRef]

146. Liu, R.H. Potential synergy of phytochemicals in cancer prevention: Mechanism of action. J. Nutr. 2004, 134, 3479s-3485s. [CrossRef] [PubMed]

147. Kausar, H.; Jeyabalan, J.; Aqil, F.; Chabba, D.; Sidana, J.; Singh, I.P.; Gupta, R.C. Berry anthocyanidins synergistically suppress growth and invasive potential of human non-small-cell lung cancer cells. Cancer Lett. 2012, 325, 54-62. [CrossRef]

148. Wang, H.; Zhang, H.; Tang, L.; Chen, H.; Wu, C.; Zhao, M.; Yang, Y.; Chen, X.; Liu, G. Resveratrol inhibits TGF-beta1-induced epithelial-to-mesenchymal transition and suppresses lung cancer invasion and metastasis. Toxicology 2013, 303, 139-146. [CrossRef] [PubMed]

149. Rigalli, J.P.; Tocchetti, G.N.; Arana, M.R.; Villanueva, S.S.; Catania, V.A.; Theile, D.; Ruiz, M.L.; Weiss, J. The phytoestrogen genistein enhances multidrug resistance in breast cancer cell lines by translational regulation of ABC transporters. Cancer Lett. 2016, 376, 165-172. [CrossRef]

150. Shi, J.; Liu, F.; Zhang, W.; Liu, X.; Lin, B.; Tang, X. Epigallocatechin-3-gallate inhibits nicotine-induced migration and invasion by the suppression of angiogenesis and epithelial-mesenchymal transition in non-small cell lung cancer cells. Oncol. Rep. 2015, 33, 2972-2980. [CrossRef] [PubMed]

151. Li, F.; Li, S.; Li, H.-B.; Deng, G.-F.; Ling, W.-H.; Wu, S.; Xu, X.-R.; Chen, F. Antiproliferative activity of peels, pulps and seeds of 61 fruits. J. Funct. Foods 2013, 5, 1298-1309. [CrossRef]

152. Li, F.; Li, S.; Li, H.B.; Deng, G.F.; Ling, W.H.; Xu, X.R. Antiproliferative activities of tea and herbal infusions. Food Funct. 2013, 4, 530-538. [CrossRef]

153. Agoston, V.; Csermely, P.; Pongor, S. Multiple weak hits confuse complex systems: A transcriptional regulatory network as an example. Phys. Rev. E Stat. Nonlinear Soft Matter Phys. 2005, 71, 051909. [CrossRef]

154. Csermely, P. Strong links are important, but weak links stabilize them. Trends Biochem. Sci. 2004, 29, 331-334. [CrossRef] [PubMed]

155. Van Duynhoven, J.P.M.; van Velzen, E.J.J.; Westerhuis, J.A.; Foltz, M.; Jacobs, D.M.; Smilde, A.K. Nutrikinetics: Concept, technologies, applications, perspectives. Trends Food Sci. Technol. 2012, 26, 4-13. [CrossRef]

156. Lee, D.H.; Kim, M.J.; Ahn, J.; Lee, S.H.; Lee, H.; Kim, J.H.; Park, S.H.; Jang, Y.J.; Ha, T.Y.; Jung, C.H. Nutrikinetics of Isoflavone Metabolites After Fermented Soybean Product (Cheonggukjang) Ingestion in Ovariectomized Mice. Mol. Nutr. Food Res. 2017, 61. [CrossRef]

157. De Vos, W.M.; Castenmiller, J.J.M.; Hamer, R.J.; Brummer, R.J.M. Nutridynamics—Studying the dynamics of food components in products and in the consumer. Curr. Opin. Biotechnol. 2006, 17, 217-225. [CrossRef] 
158. Serrano, J.C.; Jove, M.; Gonzalo, H.; Pamplona, R.; Portero-Otin, M. Nutridynamics: Mechanism(s) of action of bioactive compounds and their effects. Int. J. Food Sci. Nutr. 2015, 66, S22-S30. [CrossRef]

159. Khan, N.; Syed, D.N.; Ahmad, N.; Mukhtar, H. Fisetin: A dietary antioxidant for health promotion. Antioxid. Redox Signal. 2013, 19, 151-162. [CrossRef] [PubMed]

160. Cory, H.; Passarelli, S.; Szeto, J.; Tamez, M.; Mattei, J. The Role of Polyphenols in Human Health and Food Systems: A Mini-Review. Front. Nutr. 2018, 5. [CrossRef]

161. Singh, A.; Holvoet, S.; Mercenier, A. Dietary polyphenols in the prevention and treatment of allergic diseases. Clin. Exp. Allergy 2011, 41, 1346-1359. [CrossRef]

162. Pérez-Jiménez, J.; Neveu, V.; Vos, F.; Scalbert, A. Identification of the 100 richest dietary sources of polyphenols: An application of the Phenol-Explorer database. Eur. J. Clin. Nutr. 2010, 64, S112. [CrossRef] [PubMed]

163. Williamson, G.; Holst, B. Dietary reference intake (DRI) value for dietary polyphenols: Are we heading in the right direction? Br. J. Nutr. 2008, 99, S55-S58. [CrossRef]

164. Crowe, K.M.; Francis, C. Position of the academy of nutrition and dietetics: Functional foods. J. Acad. Nutr. Diet. 2013, 113, 1096-1103. [CrossRef]

165. Auclair, S.; Chironi, G.; Milenkovic, D.; Hollman, P.; Renard, C.; Megnien, J.; Gariepy, J.; Paul, J.; Simon, A.; Scalbert, A. The regular consumption of a polyphenol-rich apple does not influence endothelial function: A randomised double-blind trial in hypercholesterolemic adults. Eur. J. Clin. Nutr. 2010, 64, 1158. [CrossRef]

166. Habas, K.; Brinkworth, M.H.; Anderson, D. Diethylstilbestrol induces oxidative DNA damage, resulting in apoptosis of spermatogonial stem cells in vitro. Toxicology 2017, 382, 117-121. [CrossRef]

167. Anderson, A.L.; Harris, T.B.; Tylavsky, F.A.; Perry, S.E.; Houston, D.K.; Lee, J.S.; Kanaya, A.M.; Sahyoun, N.R. Dietary patterns, insulin sensitivity and inflammation in older adults. Eur. J. Clin. Nutr. 2012, 66, 18. [CrossRef] [PubMed]

168. Magrone, T.; Jirillo, E. Influence of polyphenols on allergic immune reactions: Mechanisms of action. Proc. Nutr. Soc. 2012, 71, 316-321. [CrossRef] [PubMed]

169. Sroka, Z.; Cisowski, W. Hydrogen peroxide scavenging, antioxidant and anti-radical activity of some phenolic acids. Food Chem. Toxicol. 2003, 41,753-758. [CrossRef]

170. Saeidnia, S.; Abdollahi, M. Antioxidants: Friends or foe in prevention or treatment of cancer: The debate of the century. Toxicol. Appl. Pharmacol. 2013, 271, 49-63. [CrossRef] [PubMed]

171. Upadhyay, S.; Dixit, M. Role of Polyphenols and Other Phytochemicals on Molecular Signaling. Oxid. Med. Cell. Longev. 2015, 2015, 504253. [CrossRef]

172. Wang, S.; Lin, H.; Cong, W. Chinese Medicines Improve Perimenopausal Symptoms Induced by Surgery, Chemoradiotherapy, or Endocrine Treatment for Breast Cancer. Front. Pharmacol. 2019, 10, 174. [CrossRef] [PubMed]

173. Lambert, J.D.; Sang, S.; Lu, A.Y.; Yang, C.S. Metabolism of dietary polyphenols and possible interactions with drugs. Curr. Drug Metab. 2007, 8, 499-507. [CrossRef]

174. Tham, D.M.; Gardner, C.D.; Haskell, W.L. Clinical review 97: Potential health benefits of dietary phytoestrogens: A review of the clinical, epidemiological, and mechanistic evidence. J. Clin Endocrinol. Metab. 1998, 83, 2223-2235. [CrossRef]

175. Limonta, P.; Moretti, R.M.; Marzagalli, M.; Fontana, F.; Raimondi, M.; Montagnani Marelli, M. Role of Endoplasmic Reticulum Stress in the Anticancer Activity of Natural Compounds. Int. J. Mol. Sci. 2019, 20, 961. [CrossRef] [PubMed]

176. Hasima, N.; Ozpolat, B. Regulation of autophagy by polyphenolic compounds as a potential therapeutic strategy for cancer. Cell Death Disease 2014, 5, e1509. [CrossRef]

177. Rajamanickam, S.; Agarwal, R. Natural products and colon cancer: Current status and future prospects. Drug Dev. Res. 2008, 69, 460-471. [CrossRef]

178. Taxvig, C.; Elleby, A.; Sonne-Hansen, K.; Bonefeld-Jørgensen, E.C.; Vinggaard, A.M.; Lykkesfeldt, A.E.; Nellemann, C. Effects of Nutrition Relevant Mixtures of Phytoestrogens on Steroidogenesis, Aromatase, Estrogen, and Androgen Activity. Nutr. Cancer 2009, 62, 122-131. [CrossRef]

179. Wang, L.Q. Mammalian phytoestrogens: Enterodiol and enterolactone. J. Chromatogr. B Anal. Technol. Biomed. Life Sci. 2002, 777, 289-309. [CrossRef] 
180. Richter, D.; Abarzua, S.; Chrobak, M.; Vrekoussis, T.; Weissenbacher, T.; Kuhn, C.; Schulze, S.; Kupka, M.S.; Friese, K.; Briese, V.; et al. Effects of phytoestrogen extracts isolated from pumpkin seeds on estradiol production and ER/PR expression in breast cancer and trophoblast tumor cells. Nutr. Cancer 2013, 65, 739-745. [CrossRef] [PubMed]

181. Teiten, M.-H.; Gaascht, F.; Cronauer, M.; Henry, E.; Dicato, M.; Diederich, M. Anti-proliferative potential of curcumin in androgen-dependent prostate cancer cells occurs through modulation of the Wingless signaling pathway. Int. J. Oncol. 2011, 38, 603-611. [PubMed]

182. Masuda, M.; Suzui, M.; Lim, J.T.; Deguchi, A.; Soh, J.W.; Weinstein, I.B. Epigallocatechin-3-gallate decreases VEGF production in head and neck and breast carcinoma cells by inhibiting EGFR-related pathways of signal transduction. J. Exp. Ther. Oncol. 2002, 2, 350-359. [CrossRef] [PubMed]

183. Jackson, C.J.C.; Paliyath, G. Functional Foods And Nutraceuticals; John Wiley \& Sons: New York, NY, USA, 2011; pp. 11-43. [CrossRef]

184. Morbidelli, L. Polyphenol-based nutraceuticals for the control of angiogenesis: Analysis of the critical issues for human use. Pharmacol. Res. 2016, 111, 384-393. [CrossRef] [PubMed]

185. Liu, H.; Yang, J.; Li, L.; Shi, W.; Yuan, X.; Wu, L. The Natural Occurring Compounds Targeting Endoplasmic Reticulum Stress. Evid.-Based Complement. Alternat. Med. eCAM 2016, 2016, 7831282. [CrossRef]

186. Fu, Y.; Chang, H.; Peng, X.; Bai, Q.; Yi, L.; Zhou, Y.; Zhu, J.; Mi, M. Resveratrol inhibits breast cancer stem-like cells and induces autophagy via suppressing Wnt/ $\beta$-catenin signaling pathway. PLoS ONE 2014, 9, e102535. [CrossRef]

187. Nabavi, S.F.; Sureda, A.; Dehpour, A.R.; Shirooie, S.; Silva, A.S.; Devi, K.P.; Ahmed, T.; Ishaq, N.; Hashim, R.; Sobarzo-Sánchez, E.; et al. Regulation of autophagy by polyphenols: Paving the road for treatment of neurodegeneration. Biotechnol. Adv. 2018, 36, 1768-1778. [CrossRef]

188. Hanhineva, K.; Törrönen, R.; Bondia-Pons, I.; Pekkinen, J.; Kolehmainen, M.; Mykkänen, H.; Poutanen, K. Impact of dietary polyphenols on carbohydrate metabolism. Int. J. Mol. Sci. 2010, 11, 1365-1402. [CrossRef]

189. Aryaeian, N.; Sedehi, S.K.; Arablou, T. Polyphenols and their effects on diabetes management: A review. Med. J. Islam. Republ. Iran 2017, 31, 134. [CrossRef]

190. Sharma, S.; Rana, S.; Patial, V.; Gupta, M.; Bhushan, S.; Padwad, Y.S. Antioxidant and hepatoprotective effect of polyphenols from apple pomace extract via apoptosis inhibition and Nrf2 activation in mice. Hum. Exp. Toxicol. 2016, 35, 1264-1275. [CrossRef] [PubMed]

191. Quan, M.; Li, Q.; Zhao, P.; Tian, C. Chemical composition and hepatoprotective effect of free phenolic extract from barley during malting process. Sci. Rep. 2018, 8, 4460. [CrossRef] [PubMed]

192. Eid, H.H.; Labib, R.M.; Hamid, N.S.A.; Hamed, M.A.; Ross, S.A. Hepatoprotective and antioxidant polyphenols from a standardized methanolic extract of the leaves of Liquidambar styraciflua L. Bull. Faculty Pharm. Cairo Univ. 2015, 53, 117-127. [CrossRef]

193. Shivashankara, A.R.; Kumar, A.; Ravi, R.; Simon, P.; Rai, P.; Francis, A.; Baliga, M.S. Chapter 55-Hepatoprotective Effects of Green Tea and its Polyphenols: Preclinical Observations. In Polyphenols in Human Health and Disease; Watson, R.R., Preedy, V.R., Zibadi, S., Eds.; Academic Press: San Diego, CA, USA, 2014; pp. 715-721. [CrossRef]

194. Sun, L.; Meng, Y.; Sun, J.; Guo, Y. Characterization, antioxidant activities and hepatoprotective effects of polysaccharides from pre-pressing separation Fuji apple peel. CyTA-J. Food 2017, 15, 307-319. [CrossRef]

195. Holst, B.; Williamson, G. A critical review of the bioavailability of glucosinolates and related compounds. Nat. Prod. Rep. 2004, 21, 425-447. [CrossRef]

196. Manach, C.; Williamson, G.; Morand, C.; Scalbert, A.; Remesy, C. Bioavailability and bioefficacy of polyphenols in humans. I. Review of 97 bioavailability studies. Am. J. Clin. Nutr. 2005, 81, 230s-242s. [CrossRef] [PubMed]

197. Erlund, I.; Meririnne, E.; Alfthan, G.; Aro, A. Plasma kinetics and urinary excretion of the flavanones naringenin and hesperetin in humans after ingestion of orange juice and grapefruit juice. J. Nutr. 2001, 131, 235-241. [CrossRef]

198. Shephard, S.E.; Zogg, M.; Burg, G.; Panizzon, R.G. Measurement of 5-methoxypsoralen and 8-methoxypsoralen in saliva of PUVA patients as a noninvasive, clinically relevant alternative to monitoring in blood. Arch. Dermatol. Res. 1999, 291, 491-499. [CrossRef] [PubMed] 
199. Kuijsten, A.; Arts, I.C.; Vree, T.B.; Hollman, P.C. Pharmacokinetics of enterolignans in healthy men and women consuming a single dose of secoisolariciresinol diglucoside. J. Nutr. 2005, 135, 795-801. [CrossRef] [PubMed]

200. Undevia, S.D.; Gomez-Abuin, G.; Ratain, M.J. Pharmacokinetic variability of anticancer agents. Nat. Rev. Cancer 2005, 5, 447-458. [CrossRef]

201. Goldin, B.R. In situ bacterial metabolism and colon mutagens. Annu. Revi. Microbiol. 1986, 40, $367-393$. [CrossRef] [PubMed]

202. Rechner, A.R.; Smith, M.A.; Kuhnle, G.; Gibson, G.R.; Debnam, E.S.; Srai, S.K.; Moore, K.P.; Rice-Evans, C.A. Colonic metabolism of dietary polyphenols: Influence of structure on microbial fermentation products. Free Radic. Biol. Med. 2004, 36, 212-225. [CrossRef] [PubMed]

203. Keppler, K.; Humpf, H.U. Metabolism of anthocyanins and their phenolic degradation products by the intestinal microflora. Bioorg. Med. Chem. 2005, 13, 5195-5205. [CrossRef] [PubMed]

204. Larrosa, M.; Yanez-Gascon, M.J.; Selma, M.V.; Gonzalez-Sarrias, A.; Toti, S.; Ceron, J.J.; Tomas-Barberan, F.; Dolara, P.; Espin, J.C. Effect of a low dose of dietary resveratrol on colon microbiota, inflammation and tissue damage in a DSS-induced colitis rat model. J. Agric. Food Chem. 2009, 57, 2211-2220. [CrossRef]

205. Anhe, F.F.; Roy, D.; Pilon, G.; Dudonne, S.; Matamoros, S.; Varin, T.V.; Garofalo, C.; Moine, Q.; Desjardins, Y.; Levy, E.; et al. A polyphenol-rich cranberry extract protects from diet-induced obesity, insulin resistance and intestinal inflammation in association with increased Akkermansia spp. population in the gut microbiota of mice. Gut 2015, 64, 872-883. [CrossRef] [PubMed]

206. Garcia-Calvo, M.; Lisnock, J.; Bull, H.G.; Hawes, B.E.; Burnett, D.A.; Braun, M.P.; Crona, J.H.; Davis, H.R., Jr.; Dean, D.C.; Detmers, P.A.; et al. The target of ezetimibe is Niemann-Pick C1-Like 1 (NPC1L1). Proc. Natl. Acad. Sci. USA 2005, 102, 8132-8137. [CrossRef] [PubMed]

207. Ghosal, A.; Hapangama, N.; Yuan, Y.; Achanfuo-Yeboah, J.; Iannucci, R.; Chowdhury, S.; Alton, K.; Patrick, J.E.; Zbaida, S. Identification of human UDP-glucuronosyltransferase enzyme(s) responsible for the glucuronidation of ezetimibe (Zetia). Drug Metab. Dispos. 2004, 32, 314-320. [CrossRef]

208. Patel, J.; Sheehan, V.; Gurk-Turner, C. Ezetimibe (Zetia): A new type of lipid-lowering agent. Proc. Bayl. Univ. Med. Cent. 2003, 16, 354-358. [CrossRef] [PubMed]

209. Temsamani, J.; Bonnafous, C.; Rousselle, C.; Fraisse, Y.; Clair, P.; Granier, L.A.; Rees, A.R.; Kaczorek, M.; Scherrmann, J.M. Improved brain uptake and pharmacological activity profile of morphine-6-glucuronide using a peptide vector-mediated strategy. J. Pharmacol. Exp. Ther. 2005, 313, 712-719. [CrossRef]

210. Klimas, R.; Mikus, G. Morphine-6-glucuronide is responsible for the analgesic effect after morphine administration: A quantitative review of morphine, morphine-6-glucuronide, and morphine-3-glucuronide. Br. J. Anaesth. 2014, 113, 935-944. [CrossRef]

211. MacDougall, J.M.; Zhang, X.D.; Polgar, W.E.; Khroyan, T.V.; Toll, L.; Cashman, J.R. Design, chemical synthesis, and biological evaluation of thiosaccharide analogues of morphine- and codeine-6-glucuronide. J. Med. Chem. 2004, 47, 5809-5815. [CrossRef]

212. Gordon, H.L. Morphine intoxication in renal failure: The role of morphine-6-glucuronide. Br. Med. J. Clin. Res. Ed. 1986, 293, 818-819. [CrossRef] [PubMed]

213. Mukker, J. Pharmacokinetic and Pharmacodynamic Studies on Flaxseed Lignans. Ph.D. Thesis, University of Saskatchewan, Saskatoon, SK, Canada, 2013.

214. Brand, W.; Schutte, M.E.; Williamson, G.; van Zanden, J.J.; Cnubben, N.H.; Groten, J.P.; van Bladeren, P.J.; Rietjens, I.M. Flavonoid-mediated inhibition of intestinal ABC transporters may affect the oral bioavailability of drugs, food-borne toxic compounds and bioactive ingredients. Biomed. Pharmacother. 2006, 60, 508-519. [CrossRef] [PubMed]

215. Batra, P.; Sharma, A.K. Anti-cancer potential of flavonoids: Recent trends and future perspectives. 3 Biotech 2013, 3, 439-459. [CrossRef] [PubMed]

216. Sesink, A.L.; Arts, I.C.; de Boer, V.C.; Breedveld, P.; Schellens, J.H.; Hollman, P.C.; Russel, F.G. Breast cancer resistance protein (Bcrp1/Abcg2) limits net intestinal uptake of quercetin in rats by facilitating apical efflux of glucuronides. Mol. Pharmacol. 2005, 67, 1999-2006. [CrossRef]

217. Wang, Y.; Cao, J.; Zeng, S. Involvement of P-glycoprotein in regulating cellular levels of Ginkgo flavonols: Quercetin, kaempferol, and isorhamnetin. J. Pharm. Pharmacol. 2005, 57, 751-758. [CrossRef] [PubMed] 
218. Miguel, V.; Otero, J.A.; Garcia-Villalba, R.; Tomas-Barberan, F.; Espin, J.C.; Merino, G.; Alvarez, A.I. Role of ABCG2 in transport of the mammalian lignan enterolactone and its secretion into milk in Abcg2 knockout mice. Drug Metab. Dispos. 2014, 42, 943-946. [CrossRef]

219. Cascorbi, I. Role of pharmacogenetics of ATP-binding cassette transporters in the pharmacokinetics of drugs. Pharmacol. Ther. 2006, 112, 457-473. [CrossRef]

220. Kerb, R. Implications of genetic polymorphisms in drug transporters for pharmacotherapy. Cancer Lett. 2006, 234, 4-33. [CrossRef]

221. Ieiri, I.; Takane, H.; Hirota, T.; Otsubo, K.; Higuchi, S. Genetic polymorphisms of drug transporters: Pharmacokinetic and pharmacodynamic consequences in pharmacotherapy. Expert Opin. Drug Metab. Toxicol. 2006, 2, 651-674. [CrossRef]

222. Figueira, I.; Menezes, R.; Macedo, D.; Costa, I.; Dos Santos, C.N. Polyphenols Beyond Barriers: A Glimpse into the Brain. Curr. Neuropharmacol. 2017, 15, 562-594. [CrossRef]

223. Gee, J.M.; DuPont, M.S.; Day, A.J.; Plumb, G.W.; Williamson, G.; Johnson, I.T. Intestinal transport of quercetin glycosides in rats involves both deglycosylation and interaction with the hexose transport pathway. J. Nutr. 2000, 130, 2765-2771. [CrossRef]

224. Hussain, S.A.; Sulaiman, A.A.; Alhaddad, H.; Alhadidi, Q. Natural polyphenols: Influence on membrane transporters. J. Intercult. Ethnopharmacol. 2016, 5, 97-104. [CrossRef] [PubMed]

225. Hollman, P.C.; de Vries, J.H.; van Leeuwen, S.D.; Mengelers, M.J.; Katan, M.B. Absorption of dietary quercetin glycosides and quercetin in healthy ileostomy volunteers. Am. J. Clin. Nutr. 1995, 62, 1276-1282. [CrossRef] [PubMed]

226. Vauzour, D.; Rodriguez-Mateos, A.; Corona, G.; Oruna-Concha, M.J.; Spencer, J.P. Polyphenols and human health: Prevention of disease and mechanisms of action. Nutrients 2010, 2, 1106-1131. [CrossRef]

227. Janle, E.M.; Lila, M.A.; Grannan, M.; Wood, L.; Higgins, A.; Yousef, G.G.; Rogers, R.B.; Kim, H.; Jackson, G.S.; Ho, L.; et al. Pharmacokinetics and tissue distribution of 14C-labeled grape polyphenols in the periphery and the central nervous system following oral administration. J. Med. Food 2010, 13, 926-933. [CrossRef]

228. Chen, L.; Lee, M.J.; Li, H.; Yang, C.S. Absorption, distribution, elimination of tea polyphenols in rats. Drug Metab. Dispos. 1997, 25, 1045-1050. [PubMed]

229. Gester, S.; Wuest, F.; Pawelke, B.; Bergmann, R.; Pietzsch, J. Synthesis and biodistribution of an 18F-labelled resveratrol derivative for small animal positron emission tomography. Amino Acids 2005, 29, 415-428. [CrossRef] [PubMed]

230. D'Archivio, M.; Filesi, C.; Vari, R.; Scazzocchio, B.; Masella, R. Bioavailability of the polyphenols: Status and controversies. Int. J. Mol. Sci. 2010, 11, 1321-1342. [CrossRef] [PubMed]

231. Teng, H.; Chen, L. Polyphenols and Bioavailability: An update. Crit. Rev. Food Sci. Nutr. 2018. [CrossRef]

232. Murray, T.; Kang, J.; Astheimer, L.; Price, W.E. Tissue distribution of lignans in rats in response to diet, dose-response, and competition with isoflavones. J. Agric. Food Chem. 2007, 55, 4907-4912. [CrossRef]

233. Saarinen, N.M.; Thompson, L.U. Prolonged administration of secoisolariciresinol diglycoside increases lignan excretion and alters lignan tissue distribution in adult male and female rats. Br. J. Nutr. 2010, 104, 833-841. [CrossRef] [PubMed]

234. Mukker, J.K.; Singh, R.S.P.; Muir, A.D.; Krol, E.S.; Alcorn, J. Comparative pharmacokinetics of purified flaxseed and associated mammalian lignans in male Wistar rats. Br. J. Nutr. 2015, 113, 749-757. [CrossRef] [PubMed]

235. Kurlbaum, M.; Hogger, P. Plasma protein binding of polyphenols from maritime pine bark extract (USP). J. Pharm. Biomed. Anal. 2011, 54, 127-132. [CrossRef]

236. Xiao, J.; Zhao, Y.; Wang, H.; Yuan, Y.; Yang, F.; Zhang, C.; Yamamoto, K. Noncovalent interaction of dietary polyphenols with common human plasma proteins. J. Agric. Food Chem. 2011, 59, 10747-10754. [CrossRef]

237. Xiao, J.; Kai, G. A review of dietary polyphenol-plasma protein interactions: Characterization, influence on the bioactivity, and structure-affinity relationship. Crit. Rev. Food Sci. Nutr. 2012, 52, 85-101. [CrossRef]

238. Blagosklonny, M.V. Treatment with inhibitors of caspases, that are substrates of drug transporters, selectively permits chemotherapy-induced apoptosis in multidrug-resistant cells but protects normal cells. Leukemia 2001, 15, 936-941. [CrossRef]

239. Wu, C.P.; Calcagno, A.M.; Hladky, S.B.; Ambudkar, S.V.; Barrand, M.A. Modulatory effects of plant phenols on human multidrug-resistance proteins 1, 4 and 5 (ABCC1, 4 and 5). FEBS J. 2005, 272, 4725-4740. [CrossRef] [PubMed] 
240. Jodoin, J.; Demeule, M.; Beliveau, R. Inhibition of the multidrug resistance P-glycoprotein activity by green tea polyphenols. Biochim. biophys. Acta 2002, 1542, 149-159. [CrossRef]

241. Liu, Z.; Hu, M. Natural polyphenol disposition via coupled metabolic pathways. Expert Opin. Drug Metab. Toxicol. 2007, 3, 389-406. [CrossRef]

242. Scheepens, A.; Tan, K.; Paxton, J.W. Improving the oral bioavailability of beneficial polyphenols through designed synergies. Genes Nutr. 2010, 5, 75-87. [CrossRef]

243. Hu, M.; Wu, B.; Liu, Z. Bioavailability of Polyphenols and Flavonoids in the Era of Precision Medicine. Mol. Pharm. 2017, 14, 2861-2863. [CrossRef]

244. Amararathna, M.; Johnston, M.R.; Rupasinghe, H.P. Plant Polyphenols as Chemopreventive Agents for Lung Cancer. Int. J. Mol. Sci. 2016, 17, 1352. [CrossRef] [PubMed]

245. Stevens, J.F.; Maier, C.S. The Chemistry of Gut Microbial Metabolism of Polyphenols. Phytochem. Rev. 2016, 15, 425-444. [CrossRef]

246. Marin, L.; Miguelez, E.M.; Villar, C.J.; Lombo, F. Bioavailability of dietary polyphenols and gut microbiota metabolism: Antimicrobial properties. Biomed. Res. Int. 2015, 2015, 905215. [CrossRef]

247. Most types of cancer not due to 'bad luck' IARC responds to scientific article claiming that environmental and lifestyle factors account for less than one third of cancers. Centr. Eur. J. Public Health 2015, 23, 87.

248. Weinberg, C.R.; Zaykin, D. Is bad luck the main cause of cancer? J. Natl. Cancer Inst 2015, 107. [CrossRef]

249. Rozhok, A.I.; Wahl, G.M.; DeGregori, J. A Critical Examination of the "Bad Luck" Explanation of Cancer Risk. Cancer Prev. Res. 2015, 8, 762-764. [CrossRef] [PubMed]

250. Tomasetti, C.; Vogelstein, B. Cancer etiology. Variation in cancer risk among tissues can be explained by the number of stem cell divisions. Science 2015, 347, 78-81. [CrossRef] [PubMed]

251. Cao, S.; Zhang, C.; Xu, Y. Somatic mutations may not be the primary drivers of cancer formation. Int. J. Cancer 2015, 137, 2762-2765. [CrossRef]

252. Lichtenstein, A.V. Cancer: Bad Luck or Punishment? Biochem. Biokhim. 2017, 82, 75-80. [CrossRef]

253. Gleichenhagen, M.; Schieber, A. Current challenges in polyphenol analytical chemistry. Curr. Opin. Food Sci. 2016, 7, 43-49. [CrossRef]

254. Plaza, M.; Domínguez-Rodríguez, G.; Castro-Puyana, M.; Marina, M.L. 6-Polyphenols analysis and related challenges. In Polyphenols: Properties, Recovery, and Applications; Galanakis, C.M., Ed.; Woodhead Publishing: Cambridge, UK, 2018; pp. 177-232. [CrossRef]

255. Opara, E.I.; Chohan, M. Culinary Herbs and Spices: Their Bioactive Properties, the Contribution of Polyphenols and the Challenges in Deducing Their True Health Benefits. Int. J. Mol. Sci. 2014, 15, 19183-19202. [CrossRef] [PubMed]

256. Singh, M.; Arseneault, M.; Sanderson, T.; Murthy, V.; Ramassamy, C. Challenges for research on polyphenols from foods in Alzheimer's disease: Bioavailability, metabolism, and cellular and molecular mechanisms. J. Agric. Food Chem. 2008, 56, 4855-4873. [CrossRef] [PubMed]

257. Brglez Mojzer, E.; Knez Hrnčič, M.; Škerget, M.; Knez, Ž.; Bren, U. Polyphenols: Extraction Methods, Antioxidative Action, Bioavailability and Anticarcinogenic Effects. Molecules 2016, 21, 901. [CrossRef] [PubMed]

258. Smoliga, J.M.; Vang, O.; Baur, J.A. Challenges of translating basic research into therapeutics: Resveratrol as an example. J. Gerontol. Ser. A Biol. Sci. Med. Sci. 2012, 67, 158-167. [CrossRef]

259. Vittorio, O.; Curcio, M.; Cojoc, M.; Goya, G.F.; Hampel, S.; Iemma, F.; Dubrovska, A.; Cirillo, G. Polyphenols delivery by polymeric materials: Challenges in cancer treatment. Drug Deliv. 2017, 24, 162-180. [CrossRef]

260. Gao, S.; Hu, M. Bioavailability challenges associated with development of anti-cancer phenolics. Mini Rev. Med. Chem. 2010, 10, 550-567. [CrossRef] [PubMed]

261. Yang, L.; Cao, Y.L.; Jiang, J.G.; Lin, Q.S.; Chen, J.; Zhu, L. Response surface optimization of ultrasound-assisted flavonoids extraction from the flower of Citrus aurantium L. var. amara Engl. J. Sep. Sci. 2010, 33, 1349-1355. [CrossRef] [PubMed]

262. Wang, X.; Wu, Y.; Chen, G.; Yue, W.; Liang, Q.; Wu, Q. Optimisation of ultrasound assisted extraction of phenolic compounds from Sparganii rhizoma with response surface methodology. Ultrason. Sonochem. 2013, 20, 846-854. [CrossRef]

263. Kurepa, J.; Nakabayashi, R.; Paunesku, T.; Suzuki, M.; Saito, K.; Woloschak, G.E.; Smalle, J.A. Direct isolation of flavonoids from plants using ultra-small anatase $\mathrm{TiO}(2)$ nanoparticles. Plant J. Cell Mol. Biol. 2014, 77, 443-453. [CrossRef] [PubMed] 
264. Zheng, L.L.; Wang, D.; Li, Y.Y.; Peng, H.Y.; Yuan, M.Y.; Gao, F. Ultrasound-assisted extraction of total flavonoids from Aconitum gymnandrum. Pharmacogn. Mag. 2014, 10, S141-S146. [CrossRef] [PubMed]

265. Zhou, J.; Du, G.; Chen, J. Novel fermentation processes for manufacturing plant natural products. Curr. Opin. Biotechnol. 2014, 25, 17-23. [CrossRef] [PubMed]

266. Wu, J.; Du, G.; Zhou, J.; Chen, J. Systems metabolic engineering of microorganisms to achieve large-scale production of flavonoid scaffolds. J. Biotechnol. 2014, 188, 72-80. [CrossRef]

267. Santos, C.N.; Koffas, M.; Stephanopoulos, G. Optimization of a heterologous pathway for the production of flavonoids from glucose. Metab. Eng. 2011, 13, 392-400. [CrossRef]

268. Wu, J.; Du, G.; Zhou, J.; Chen, J. Metabolic engineering of Escherichia coli for (2S)-pinocembrin production from glucose by a modular metabolic strategy. Metab. Eng. 2013, 16, 48-55. [CrossRef] [PubMed]

269. Wang, Y.; Chen, S.; Yu, O. Metabolic engineering of flavonoids in plants and microorganisms. Appl. Microbiol. Biotechnol. 2011, 91, 949-956. [CrossRef] [PubMed]

270. Vannelli, T.; Wei Qi, W.; Sweigard, J.; Gatenby, A.A.; Sariaslani, F.S. Production of p-hydroxycinnamic acid from glucose in Saccharomyces cerevisiae and Escherichia coli by expression of heterologous genes from plants and fungi. Metab. Eng. 2007, 9, 142-151. [CrossRef] [PubMed]

271. Chen, L.C.; Chen, Y.C.; Su, C.Y.; Hong, C.S.; Ho, H.O.; Sheu, M.T. Development and characterization of self-assembling lecithin-based mixed polymeric micelles containing quercetin in cancer treatment and an in vivo pharmacokinetic study. Int. J. Nanomed. 2016, 11, 1557-1566. [CrossRef]

272. Kumar, P.; Sharma, G.; Kumar, R.; Singh, B.; Malik, R.; Katare, O.P.; Raza, K. Promises of a biocompatible nanocarrier in improved brain delivery of quercetin: Biochemical, pharmacokinetic and biodistribution evidences. Int. J. Pharm. 2016, 515, 307-314. [CrossRef] [PubMed]

273. Macedo, A.S.; Quelhas, S.; Silva, A.M.; Souto, E.B. Nanoemulsions for delivery of flavonoids: Formulation and in vitro release of rutin as model drug. Pharm. Dev. Technol. 2014, 19, 677-680. [CrossRef] [PubMed]

274. Yi, T.; Liu, C.; Zhang, J.; Wang, F.; Wang, J.; Zhang, J. A new drug nanocrystal self-stabilized Pickering emulsion for oral delivery of silybin. Eur. J. Pharm. Sci. 2017, 96, 420-427. [CrossRef]

275. Di, Y.; Ji, S.; Wolf, P.; Krol, E.S.; Alcorn, J. Enterolactone glucuronide and $\beta$-glucuronidase in antibody directed enzyme prodrug therapy for targeted prostate cancer cell treatment. AAPS PharmSciTech 2017, 18, 2336-2345. [CrossRef]

276. Docampo, M.; Olubu, A.; Wang, X.; Pasinetti, G.; Dixon, R.A. Glucuronidated Flavonoids in Neurological Protection: Structural Analysis and Approaches for Chemical and Biological Synthesis. J. Agric. Food Chem. 2017, 65, 7607-7623. [CrossRef] [PubMed]

277. Chen, D.; Wan, S.B.; Yang, H.; Yuan, J.; Chan, T.H.; Dou, Q.P. EGCG, green tea polyphenols and their synthetic analogs and prodrugs for human cancer prevention and treatment. Adv. Clin. Chem. 2011, 53, 155-177.

278. Terao, J.; Murota, K.; Kawai, Y. Conjugated quercetin glucuronides as bioactive metabolites and precursors of aglycone in vivo. Food Funct. 2011, 2, 11-17. [CrossRef] [PubMed]

279. Thilakarathna, S.H.; Rupasinghe, H.P. Flavonoid bioavailability and attempts for bioavailability enhancement. Nutrients 2013, 5, 3367-3387. [CrossRef] [PubMed]

280. Olthof, M.R.; Hollman, P.C.; Vree, T.B.; Katan, M.B. Bioavailabilities of quercetin-3-glucoside and quercetin-4'-glucoside do not differ in humans. J. Nutr. 2000, 130, 1200-1203. [CrossRef]

281. Tatiraju, D.V.; Bagade, V.B.; Karambelkar, P.J.; Jadhav, V.M.; Kadam, V. Natural bioenhancers: An overview. Available online: http://www.phytojournal.com/vol2Issue3/15.1.html (accessed on 30 March 2019).

282. Rinwa, P.; Kumar, A. Quercetin along with piperine prevents cognitive dysfunction, oxidative stress and neuro-inflammation associated with mouse model of chronic unpredictable stress. Arch. Pharm. Res. 2017, 40, 1166-1175. [CrossRef] [PubMed]

283. Lambert, J.D.; Hong, J.; Kim, D.H.; Mishin, V.M.; Yang, C.S. Piperine enhances the bioavailability of the tea polyphenol (-)-epigallocatechin-3-gallate in mice. J. Nutr. 2004, 134, 1948-1952. [CrossRef] [PubMed]

284. Vaidyanathan, J.B.; Walle, T. Cellular uptake and efflux of the tea flavonoid (-)epicatechin-3-gallate in the human intestinal cell line Caco-2. J. Pharmacol. Exp. Ther. 2003, 307, 745-752. [CrossRef]

285. Selma, M.V.; Espin, J.C.; Tomas-Barberan, F.A. Interaction between phenolics and gut microbiota: Role in human health. J. Agric. Food Chem. 2009, 57, 6485-6501. [CrossRef]

286. Althagafy, H.S.; Graf, T.N.; Sy-Cordero, A.A.; Gufford, B.T.; Paine, M.F.; Wagoner, J.; Polyak, S.J.; Croatt, M.P.; Oberlies, N.H. Semisynthesis, cytotoxicity, antiviral activity, and drug interaction liability of 7-O-methylated analogues of flavonolignans from milk thistle. Bioorg. Med. Chem. 2013, 21, 3919-3926. [CrossRef] 
287. Vue, B.; Zhang, S.; Zhang, X.; Parisis, K.; Zhang, Q.; Zheng, S.; Wang, G.; Chen, Q.H. Silibinin derivatives as anti-prostate cancer agents: Synthesis and cell-based evaluations. Eur. J. Med. Chem. 2016, 109, 36-46. [CrossRef]

288. Grande, F.; Parisi, O.I.; Mordocco, R.A.; Rocca, C.; Puoci, F.; Scrivano, L.; Quintieri, A.M.; Cantafio, P.; Ferla, S.; Brancale, A.; et al. Quercetin derivatives as novel antihypertensive agents: Synthesis and physiological characterization. Eur. J. Pharm. Sci. 2016, 82, 161-170. [CrossRef]

289. Kim, M.K.; Park, K.S.; Lee, C.; Park, H.R.; Choo, H.; Chong, Y. Enhanced stability and intracellular accumulation of quercetin by protection of the chemically or metabolically susceptible hydroxyl groups with a pivaloxymethyl (POM) promoiety. J. Med. Chem. 2010, 53, 8597-8607. [CrossRef] [PubMed]

290. Patra, N.; De, U.; Kang, J.A.; Kim, J.M.; Ahn, M.Y.; Lee, J.; Jung, J.H.; Chung, H.Y.; Moon, H.R.; Kim, H.S. A novel epoxypropoxy flavonoid derivative and topoisomerase II inhibitor, MHY336, induces apoptosis in prostate cancer cells. Eur. J. Pharmacol. 2011, 658, 98-107. [CrossRef]

291. He, Z.; Xu, M.; Zeng, M.; Qin, F.; Chen, J. Interactions of milk alpha- and beta-casein with malvidin-3-O-glucoside and their effects on the stability of grape skin anthocyanin extracts. Food Chem. 2016, 199, 314-322. [CrossRef]

292. Arroyo-Maya, I.J.; Campos-Teran, J.; Hernandez-Arana, A.; McClements, D.J. Characterization of flavonoid-protein interactions using fluorescence spectroscopy: Binding of pelargonidin to dairy proteins. Food Chem. 2016, 213, 431-439. [CrossRef]

293. Tang, L.; Li, S.; Bi, H.; Gao, X. Interaction of cyanidin-3-O-glucoside with three proteins. Food Chem. 2016, 196, 550-559. [CrossRef] [PubMed]

294. Singh, D.; Rawat, M.S.; Semalty, A.; Semalty, M. Quercetin-phospholipid complex: An amorphous pharmaceutical system in herbal drug delivery. Curr. Drug Discov. Technol. 2012, 9, 17-24. [CrossRef]

295. Zhang, K.; Zhang, M.; Liu, Z.; Zhang, Y.; Gu, L.; Hu, G.; Chen, X.; Jia, J. Development of quercetin-phospholipid complex to improve the bioavailability and protection effects against carbon tetrachloride-induced hepatotoxicity in SD rats. Fitoterapia 2016, 113, 102-109. [CrossRef]

296. Cimino, S.; Sortino, G.; Favilla, V.; Castelli, T.; Madonia, M.; Sansalone, S.; Russo, G.I.; Morgia, G. Polyphenols: Key Issues Involved in Chemoprevention of Prostate Cancer. Oxid. Med. Cell. Longev. 2012, $2012,8$. [CrossRef]

297. Yao, L.H.; Jiang, Y.M.; Shi, J.; Tomas-Barberan, F.A.; Datta, N.; Singanusong, R.; Chen, S.S. Flavonoids in food and their health benefits. Plant Foods Hum. Nutr. 2004, 59, 113-122. [CrossRef]

298. Kobuchi, H.; Roy, S.; Sen, C.K.; Nguyen, H.G.; Packer, L. Quercetin inhibits inducible ICAM-1 expression in human endothelial cells through the JNK pathway. Am. J. Physiol.-Cell Physiol. 1999, 277, C403-C411. [CrossRef]

299. Kong, A.N.; Yu, R.; Chen, C.; Mandlekar, S.; Primiano, T. Signal transduction events elicited by natural products: Role of MAPK and caspase pathways in homeostatic response and induction of apoptosis. Arch. Pharm. Res. 2000, 23, 1-16. [CrossRef]

300. Spencer, J.P.; Schroeter, H.; Crossthwaithe, A.J.; Kuhnle, G.; Williams, R.J.; Rice-Evans, C. Contrasting influences of glucuronidation and O-methylation of epicatechin on hydrogen peroxide-induced cell death in neurons and fibroblasts. Free Radic. Biol. Med. 2001, 31, 1139-1146. [CrossRef]

301. Schroeter, H.; Spencer, J.P.; Rice-Evans, C.; Williams, R.J. Flavonoids protect neurons from oxidized low-density-lipoprotein-induced apoptosis involving c-Jun N-terminal kinase (JNK), c-Jun and caspase-3. Biochem. J. 2001, 358, 547-557. [CrossRef]

302. Muir, A.E.; Westcott, N.; Hardman, R. Flax: The Genus Linum; CRC Press: London, UK, 2003; p. 320.

303. Bernacchia, R.; Preti, R.; Vinci, G. Chemical Composition and Health Benefits of Flaxseed. Austin J. Nutr. Food Sci. 2014, 2.

304. Shim, Y.Y.; Gui, B.; Arnison, P.G.; Wang, Y.; Reaney, M.J.T. Flaxseed (Linum usitatissimum L.) bioactive compounds and peptide nomenclature: A review. Trends Food Sci. Technol. 2014, 38, 5-20. [CrossRef]

305. Tarpila, S.; Tarpila, A.; Grohn, P.; Silvennoinen, T.; Lindberg, L. Efficacy of ground flaxseed on constipation in patients with irritable bowel syndrome. Curr. Top. Nutraceut. Res. 2004, 2, 119-125.

306. Health-Canada. Monograph: Flaxseed. Available online: http://webprod.hc-sc.gc.ca/nhpid-bdipsn/ monoReq.do?id=219 (accessed on 2 January 2018).

307. Rajaram, S. Health benefits of plant-derived alpha-linolenic acid. Am. J. Clin. Nutr 2014, 100, 443S-448S. [CrossRef] 
308. Health-Canada. Summary of Health Canada's Assessment of a Health Claim about Ground Whole Flaxseed (Bureau of Nutritional Sciences-Food Directorate, Health Products and Food Branch). Available online: https: //www.canada.ca/en/health-canada/services/food-nutrition/food-labelling/health-claims/assessments/ ground-whole-flaxseed-blood-cholesterol-lowering-nutrition-health-claims-food-labelling.html (accessed on 2 January 2018).

309. Wong, H.; Chahal, N.; Manlhiot, C.; Niedra, E.; McCrindle, B.W. Flaxseed in pediatric hyperlipidemia: A placebo-controlled, blinded, randomized clinical trial of dietary flaxseed supplementation for children and adolescents with hypercholesterolemia. JAMA Pediatr. 2013, 167, 708-713. [CrossRef]

310. Patade, A.; Devareddy, L.; Lucas, E.A.; Korlagunta, K.; Daggy, B.P.; Arjmandi, B.H. Flaxseed reduces total and LDL cholesterol concentrations in Native American postmenopausal women. J. Women's Health 2008, 17, 355-366. [CrossRef]

311. Lucas, E.A.; Wild, R.D.; Hammond, L.J.; Khalil, D.A.; Juma, S.; Daggy, B.P.; Stoecker, B.J.; Arjmandi, B.H. Flaxseed improves lipid profile without altering biomarkers of bone metabolism in postmenopausal women. J. Clin. Endocrinol. Metab. 2002, 87, 1527-1532. [CrossRef]

312. Arjmandi, B.H.; Khan, D.A.; Juma, S.; Drum, M.L.; Venkatesh, S.; Sohn, E.; Wei, L.; Derman, R. Whole flaxseed consumption lowers serum LDL-cholesterol and lipoprotein(a) concentrations in postmenopausal women. Nutr. Rese. 1998, 18, 1203-1214. [CrossRef]

313. Cunnane, S.C.; Hamadeh, M.J.; Liede, A.C.; Thompson, L.U.; Wolever, T.M.; Jenkins, D.J. Nutritional attributes of traditional flaxseed in healthy young adults. Am. J. Clin. Nutr. 1995, 61, 62-68. [CrossRef]

314. U.S.-National-Institutes-of-Health. Flaxseed and Flaxseed Oil. Available online: https://www.ncbi.nlm.nih. gov/pubmed/ (accessed on 30 March 2019).

315. Flax-Council-of-Canada. Flax: A Healthy Food. Available online: https://flaxcouncil.ca/resources/nutrition/ general-nutrition-information/flax-a-healthy-food/ (accessed on 30 March 2019).

316. Healthyflax.org. HomeHealthy Flax. Available online: https://healthyflax.org/ (accessed on 29 March 2019).

317. AmeriFlax. Flax FAQs-AmeriFlax. Available online: https://www.ameriflax.com/flax-faqs (accessed on 29 March 2019).

318. Kaur, P.; Waghmare, R.; Kumar, V.; Rasane, P.; Kaur, S.; Gat, Y. Recent advances in utilization of flaxseed as potential source for value addition. OCL 2018, 25, A304. [CrossRef]

319. Benedetti, E.; Pedone, C. Cyclolinopeptide A: Inhibitor, immunosuppressor or other? J. Pept. Sci. 2005, 11, 268-272. [CrossRef]

320. Gallo, P.; Rossi, F.; Saviano, M.; Pedone, C.; Colonna, G.; Ragone, R. Specific Interaction between Bovine Cyclophilin A and Synthetic Analogues of Cyclolinopeptide A. J. Biochem. 1998, 124, 880-885. [CrossRef]

321. Okinyo-Owiti, D.P.; Dong, Q.; Ling, B.; Jadhav, P.D.; Bauer, R.; Maley, J.M.; Reaney, M.J.T.; Yang, J.; Sammynaiken, R. Evaluating the cytotoxicity of flaxseed orbitides for potential cancer treatment. Toxicol. Rep. 2015, 2, 1014-1018. [CrossRef]

322. Korhonen, H. Technology options for new nutritional concepts. Int. J. Dairy Technol. 2002, 55, 79-88. [CrossRef]

323. Di, Y.; Jones, J.; Mansell, K.; Whiting, S.; Fowler, S.; Thorpe, L.; Billinsky, J.; Viveky, N.; Cheng, P.C.; Almousa, A.; et al. Influence of Flaxseed Lignan Supplementation to Older Adults on Biochemical and Functional Outcome Measures of Inflammation. J. Am. Coll. Nutr. 2017, 36, 646-653. [CrossRef] [PubMed]

324. Billinsky, J.; Glew, R.A.; Cornish, S.M.; Whiting, S.J.; Thorpe, L.U.; Alcorn, J.; Paus-Jenssen, L.; Hadjistavropoulos, T.; Chilibeck, P.D. No evidence of hypoglycEemia or hypotension in older adults during 6 months of flax lignan supplementation in a randomized controlled trial: A safety evaluation. Pharm. Biol. 2013, 51, 778-782. [CrossRef] [PubMed]

325. Sonestedt, E.; Wirfält, E. Enterolactone and breast cancer: Methodological issues may contribute to conflicting results in observational studies. Nutr. Res. 2010, 30, 667-677. [CrossRef] [PubMed]

326. Grosso, G.; Godos, J.; Lamuela-Raventos, R.; Ray, S.; Micek, A.; Pajak, A.; Sciacca, S.; D’Orazio, N.; Del Rio, D.; Galvano, F. A comprehensive meta-analysis on dietary flavonoid and lignan intake and cancer risk: Level of evidence and limitations. Mol. Nutr. Food Res. 2017, 61, 1600930. [CrossRef] [PubMed]

327. Wallstrom, P.; Drake, I.; Sonestedt, E.; Gullberg, B.; Bjartell, A.; Olsson, H.; Adlercreutz, H.; Tikkanen, M.J.; Wirfalt, E. Plasma enterolactone and risk of prostate cancer in middle-aged Swedish men. Eur. J. Nutr. 2018, 57, 2595-2606. [CrossRef] 
328. Johnsen, N.F.; Hausner, H.; Olsen, A.; Tetens, I.; Christensen, J.; Knudsen, K.E.; Overvad, K.; Tjonneland, A. Intake of whole grains and vegetables determines the plasma enterolactone concentration of Danish women. J. Nutr. 2004, 134, 2691-2697. [CrossRef]

329. Stattin, P.; Adlercreutz, H.; Tenkanen, L.; Jellum, E.; Lumme, S.; Hallmans, G.; Harvei, S.; Teppo, L.; Stumpf, K.; Luostarinen, T.; et al. Circulating enterolactone and prostate cancer risk: A Nordic nested case-control study. Int. J. Cancer 2002, 99, 124-129. [CrossRef]

330. Chen, J.; Thompson, L.U. Lignans and tamoxifen, alone or in combination, reduce human breast cancer cell adhesion, invasion and migration in vitro. Breast Cancer Res. Treat. 2003, 80, 163-170. [CrossRef]

331. Saarinen, N.M.; Abrahamsson, A.; Dabrosin, C. Estrogen-induced angiogenic factors derived from stromal and cancer cells are differently regulated by enterolactone and genistein in human breast cancer in vivo. Int. J. Cancer 2010, 127, 737-745. [CrossRef]

332. Hedelin, M.; Balter, K.A.; Chang, E.T.; Bellocco, R.; Klint, A.; Johansson, J.E.; Wiklund, F.; Thellenberg-Karlsson, C.; Adami, H.O.; Gronberg, H. Dietary intake of phytoestrogens, estrogen receptor-beta polymorphisms and the risk of prostate cancer. Prostate 2006, 66, 1512-1520. [CrossRef]

333. Hedelin, M.; Klint, A.; Chang, E.T.; Bellocco, R.; Johansson, J.E.; Andersson, S.O.; Heinonen, S.M.; Adlercreutz, H.; Adami, H.O.; Gronberg, H.; et al. Dietary phytoestrogen, serum enterolactone and risk of prostate cancer: The cancer prostate Sweden study (Sweden). Cancer Causes Control 2006, 17, 169-180. [CrossRef]

334. Rhee, Y. Flaxseed Lignan Metabolite, Enterolactone, Down-regulated DNA Methyltransferase, Histone Deacetylase, and Methyl-CpG-binding Domain Protein Expression in Murine Adipocytes. FASEB J. 2016, 30. [CrossRef]

335. McCann, M.J.; Gill, C.I.; Linton, T.; Berrar, D.; McGlynn, H.; Rowland, I.R. Enterolactone restricts the proliferation of the LNCaP human prostate cancer cell line in vitro. Mol. Nutr. Food Res. 2008, 52, 567-580. [CrossRef]

336. McCann, S.E.; Hootman, K.C.; Weaver, A.M.; Thompson, L.U.; Morrison, C.; Hwang, H.; Edge, S.B.; Ambrosone, C.B.; Horvath, P.J.; Kulkarni, S.A. Dietary intakes of total and specific lignans are associated with clinical breast tumor characteristics. J. Nutr. 2012, 142, 91-98. [CrossRef]

337. Chen, J.; Saggar, J.K.; Corey, P.; Thompson, L.U. Flaxseed cotyledon fraction reduces tumour growth and sensitises tamoxifen treatment of human breast cancer xenograft (MCF-7) in athymic mice. Br. J. Nutr. 2011, 105, 339-347. [CrossRef]

338. Sacco, S.M.; Chen, J.; Ganss, B.; Thompson, L.U.; Ward, W.E. Flaxseed enhances the beneficial effect of low-dose estrogen therapy at reducing bone turnover and preserving bone microarchitecture in ovariectomized rats. Appl. Physiol. Nutr. Metab. 2014, 39, 801-810. [CrossRef]

339. Chen, J.; Saggar, J.K.; Ward, W.E.; Thompson, L.U. Effects of flaxseed lignan and oil on bone health of breast-tumor-bearing mice treated with or without tamoxifen. J. Toxicol. Environ. Health A 2011, 74, 757-768. [CrossRef]

340. McCann, S.E.; Thompson, L.U.; Nie, J.; Dorn, J.; Trevisan, M.; Shields, P.G.; Ambrosone, C.B.; Edge, S.B.; Li, H.F.; Kasprzak, C.; et al. Dietary lignan intakes in relation to survival among women with breast cancer: The Western New York Exposures and Breast Cancer (WEB) Study. Breast Cancer Res. Treat. 2010, 122, 229-235. [CrossRef]

341. Saggar, J.K.; Chen, J.; Corey, P.; Thompson, L.U. Dietary flaxseed lignan or oil combined with tamoxifen treatment affects MCF-7 tumor growth through estrogen receptor- and growth factor-signaling pathways. Mol. Nutr. Food Res. 2010, 54, 415-425. [CrossRef]

342. Saggar, J.K.; Chen, J.; Corey, P.; Thompson, L.U. The effect of secoisolariciresinol diglucoside and flaxseed oil, alone and in combination, on MCF-7 tumor growth and signaling pathways. Nutr. Cancer 2010, 62, 533-542. [CrossRef]

343. Truan, J.S.; Chen, J.M.; Thompson, L.U. Flaxseed oil reduces the growth of human breast tumors (MCF-7) at high levels of circulating estrogen. Mol. Nutr. Food Res. 2010, 54, 1414-1421. [CrossRef]

344. Chen, J.; Saggar, J.K.; Corey, P.; Thompson, L.U. Flaxseed and pure secoisolariciresinol diglucoside, but not flaxseed hull, reduce human breast tumor growth (MCF-7) in athymic mice. J. Nutr. 2009, 139, 2061-2066. [CrossRef] [PubMed]

345. Serraino, M.; Thompson, L.U. The effect of flaxseed supplementation on early risk markers for mammary carcinogenesis. Cancer Lett. 1991, 60, 135-142. [CrossRef] 
346. Power, K.A.; Ward, W.E.; Chen, J.M.; Saarinen, N.M.; Thompson, L.U. Flaxseed and soy protein isolate, alone and in combination, differ in their effect on bone mass, biomechanical strength, and uterus in ovariectomized nude mice with MCF-7 human breast tumor xenografts. J. Toxicol. Environ. Health A 2007, 70, 1888-1896. [CrossRef] [PubMed]

347. Sacco, S.M.; Power, K.A.; Chen, J.; Ward, W.E.; Thompson, L.U. Interaction of sesame seed and tamoxifen on tumor growth and bone health in athymic mice. Exp. Biol. Med. 2007, 232, 754-761.

348. Herchi, W.; Arraez-Roman, D.; Trabelsi, H.; Bouali, I.; Boukhchina, S.; Kallel, H.; Segura-Carretero, A.; Fernandez-Gutierrez, A. Phenolic compounds in flaxseed: A review of their properties and analytical methods. An overview of the last decade. J. Oleo Sci. 2014, 63, 7-14. [CrossRef]

349. Adlercreutz, H.; Mazur, W. Phyto-oestrogens and Western diseases. Ann. Med. 1997, 29, 95-120. [CrossRef]

350. Brash, A.R.; Song, W.C. Structure-function features of flaxseed allene oxide synthase. J. Lipid Mediat. Cell Signal. 1995, 12, 275-282. [CrossRef]

351. Meagher, L.P.; Beecher, G.R.; Flanagan, V.P.; Li, B.W. Isolation and Characterization of the Lignans, Isolariciresinol and Pinoresinol, in Flaxseed Meal. J. Agric. Food Chem. 1999, 47, 3173-3180. [CrossRef]

352. Thompson, L.U.; Boucher, B.A.; Liu, Z.; Cotterchio, M.; Kreiger, N. Phytoestrogen content of foods consumed in Canada, including isoflavones, lignans, and coumestan. Nutr. Cancer 2006, 54, 184-201. [CrossRef]

353. Bloedon, L.T.; Szapary, P.O. Flaxseed and cardiovascular risk. Nutr. Rev. 2004, 62, 18-27. [CrossRef]

354. Struijs, K. The Lignan Macromolecule from Flaxseed: Structure and Bioconversion of Lignans. Ph.D. Thesis, Wageningen University, Wageningen, The Netherlands, 2008.

355. Ghose, K.; Selvaraj, K.; McCallum, J.; Kirby, C.W.; Sweeney-Nixon, M.; Cloutier, S.J.; Deyholos, M.; Datla, R.; Fofana, B. Identification and functional characterization of a flax UDP-glycosyltransferase glucosylating secoisolariciresinol (SECO) into secoisolariciresinol monoglucoside (SMG) and diglucoside (SDG). BMC Plant Biol. 2014, 14, 82. [CrossRef] [PubMed]

356. Umezawa, T. Diversity in lignan biosynthesis. Phytochem. Rev. 2003, 2, 371-390. [CrossRef]

357. Cortes, C.; Gagnon, N.; Benchaar, C.; da Silva, D.; Santos, G.T.; Petit, H.V. In vitro metabolism of flax lignans by ruminal and faecal microbiota of dairy cows. J. Appl. Microbiol. 2008, 105, 1585-1594. [CrossRef]

358. Ezzat, S.M.; Shouman, S.A.; Elkhoely, A.; Attia, Y.M.; Elsesy, M.S.; El Senousy, A.S.; Choucry, M.A.; El Gayed, S.H.; El Sayed, A.A.; Sattar, E.A.; et al. Anticancer potentiality of lignan rich fraction of six Flaxseed cultivars. Sci. Rep. 2018, 8, 544. [CrossRef]

359. Garros, L.; Drouet, S.; Corbin, C.; Decourtil, C.; Fidel, T.; Lebas de Lacour, J.; Leclerc, E.A.; Renouard, S.; Tungmunnithum, D.; Doussot, J.; et al. Insight into the Influence of Cultivar Type, Cultivation Year, and Site on the Lignans and Related Phenolic Profiles, and the Health-Promoting Antioxidant Potential of Flax (Linum usitatissimum L.) Seeds. Molecules 2018, 23. [CrossRef]

360. Thompson, L.U.; Rickard, S.E.; Cheung, F.; Kenaschuk, E.O.; Obermeyer, W.R. Variability in anticancer lignan levels in flaxseed. Nutr. Cancer 1997, 27, 26-30. [CrossRef] [PubMed]

361. Johnsson, P.; Kamal-Eldin, A.; Lundgren, L.N.; Aman, P. HPLC method for analysis of secoisolariciresinol diglucoside in flaxseeds. J. Agric. Food Chem. 2000, 48, 5216-5219. [CrossRef]

362. Setchell, K.D.; Lawson, A.M.; Mitchell, F.L.; Adlercreutz, H.; Kirk, D.N.; Axelson, M. Lignans in man and in animal species. Nature 1980, 287, 740-742. [CrossRef] [PubMed]

363. Setchell, K.D.; Lawson, A.M.; Conway, E.; Taylor, N.F.; Kirk, D.N.; Cooley, G.; Farrant, R.D.; Wynn, S.; Axelson, M. The definitive identification of the lignans trans-2,3-bis(3-hydroxybenzyl)-gamma-butyrolactone and 2,3-bis(3-hydroxybenzyl)butane-1,4-diol in human and animal urine. Biochem. J. 1981, 197, 447-458. [CrossRef]

364. Axelson, M.; Sjovall, J.; Gustafsson, B.E.; Setchell, K.D. Origin of lignans in mammals and identification of a precursor from plants. Nature 1982, 298, 659-660. [CrossRef]

365. Saleem, M.; Kim, H.J.; Ali, M.S.; Lee, Y.S. An update on bioactive plant lignans. Nat. Prod. Rep. 2005, 22, 696-716. [CrossRef]

366. Lignans: chemical, biological and clinical properties. Comp. Biochem. Physiol. Part A Physiol. 1991, $100,231$. [CrossRef]

367. Hatfield, R.; Vermerris, W. Lignin formation in plants. The dilemma of linkage specificity. Plant Physiol. 2001, 126, 1351-1357. [CrossRef]

368. DeVries, J.W. On defining dietary fibre. Proc. Nutr. Soc. 2003, 62, 37-43. [CrossRef] 
369. Lewis, L.B.D.; Michaël, J.; Ann, M.P.; Kye-Won, K.; Daniel, G.V.; Norman, G. Dissection of lignin macromolecular configuration and assembly: Comparison to related biochemical processes in allyl/propenyl phenol and lignan biosynthesis. Nat. Prod. Rep. 2008, 25, 1015-1090. [CrossRef]

370. Smeds, A.I.; Eklund, P.C.; Sjoholm, R.E.; Willfor, S.M.; Nishibe, S.; Deyama, T.; Holmbom, B.R. Quantification of a broad spectrum of lignans in cereals, oilseeds, and nuts. J. Agric. Food Chem. 2007, 55, 1337-1346. [CrossRef] [PubMed]

371. Kamal-Eldin, A.; Peerlkamp, N.; Johnsson, P.; Andersson, R.; Andersson, R.E.; Lundgren, L.N.; Åman, P. An oligomer from flaxseed composed of secoisolariciresinoldiglucoside and 3-hydroxy-3-methyl glutaric acid residues. Phytochemistry 2001, 58, 587-590. [CrossRef]

372. Struijs, K.; Vincken, J.P.; Doeswijk, T.G.; Voragen, A.G.; Gruppen, H. The chain length of lignan macromolecule from flaxseed hulls is determined by the incorporation of coumaric acid glucosides and ferulic acid glucosides. Phytochemistry 2009, 70, 262-269. [CrossRef]

373. Schmidt, T.J.; Klaes, M.; Sendker, J. Lignans in seeds of Linum species. Phytochemistry 2012, 82, 89-99. [CrossRef]

374. Struijs, K.; Vincken, J.P.; Verhoef, R.; Voragen, A.G.; Gruppen, H. Hydroxycinnamic acids are ester-linked directly to glucosyl moieties within the lignan macromolecule from flaxseed hulls. Phytochemistry 2008, 69, 1250-1260. [CrossRef]

375. Ford, J.D.; Huang, K.-S.; Wang, H.-B.; Davin, L.B.; Lewis, N.G. Biosynthetic Pathway to the Cancer Chemopreventive Secoisolariciresinol Diglucoside-Hydroxymethyl Glutaryl Ester-Linked Lignan Oligomers in Flax (Linum u sitatissimum) Seed. J. Nat. Prod. 2001, 64, 1388-1397. [CrossRef]

376. Yuan, J.P.; Li, X.; Xu, S.P.; Wang, J.H.; Liu, X. Hydrolysis kinetics of secoisolariciresinol diglucoside oligomers from flaxseed. J. Agric. Food Chem. 2008, 56, 10041-10047. [CrossRef] [PubMed]

377. Struijs, K.; Vincken, J.P.; Verhoef, R.; van Oostveen-van Casteren, W.H.; Voragen, A.G.; Gruppen, H. The flavonoid herbacetin diglucoside as a constituent of the lignan macromolecule from flaxseed hulls. Phytochemistry 2007, 68, 1227-1235. [CrossRef] [PubMed]

378. Kosinska, A.; Penkacik, K.; Wiczkowski, W.; Amarowicz, R. Presence of caffeic acid in flaxseed lignan macromolecule. Plant. Foods Hum. Nutr. 2011, 66, 270-274. [CrossRef] [PubMed]

379. Rowland, I.; Faughnan, M.; Hoey, L.; Wahala, K.; Williamson, G.; Cassidy, A. Bioavailability of phyto-oestrogens. Br. J. Nutr. 2003, 89, S45-S58. [CrossRef]

380. Clavel, T.; Henderson, G.; Engst, W.; Dore, J.; Blaut, M. Phylogeny of human intestinal bacteria that activate the dietary lignan secoisolariciresinol diglucoside. FEMS Microbiol. Ecol. 2006, 55, 471-478. [CrossRef]

381. Schogor, A.L.; Huws, S.A.; Santos, G.T.; Scollan, N.D.; Hauck, B.D.; Winters, A.L.; Kim, E.J.; Petit, H.V. Ruminal Prevotella spp. may play an important role in the conversion of plant lignans into human health beneficial antioxidants. PLoS ONE 2014, 9, e87949. [CrossRef]

382. Wang, C.Z.; Ma, X.Q.; Yang, D.H.; Guo, Z.R.; Liu, G.R.; Zhao, G.X.; Tang, J.; Zhang, Y.N.; Ma, M.; Cai, S.Q.; et al. Production of enterodiol from defatted flaxseeds through biotransformation by human intestinal bacteria. BMC Microbiol. 2010, 10, 115. [CrossRef] [PubMed]

383. Clavel, T.; Henderson, G.; Alpert, C.A.; Philippe, C.; Rigottier-Gois, L.; Dore, J.; Blaut, M. Intestinal bacterial communities that produce active estrogen-like compounds enterodiol and enterolactone in humans. Appl. Environ. Microbiol. 2005, 71, 6077-6085. [CrossRef] [PubMed]

384. Clavel, T.; Borrmann, D.; Braune, A.; Dore, J.; Blaut, M. Occurrence and activity of human intestinal bacteria involved in the conversion of dietary lignans. Anaerobe 2006, 12, 140-147. [CrossRef]

385. Zhou, W.; Wang, G.; Han, Z.; Yao, W.; Zhu, W. Metabolism of flaxseed lignans in the rumen and its impact on ruminal metabolism and flora. Anim. Feed Sci. Technol. 2009, 150, 18-26. [CrossRef]

386. Jung, E.; Choi, K.-Y.; Jung, D.-h.; Yun, H.; Kim, B.-G. Ortho-hydroxylation of mammalian lignan enterodiol by cytochrome P450s from Actinomycetes sp. Korean J. Chem. Eng. 2014, 32, 471-477. [CrossRef]

387. Qiu, S.-X.; Lu, Z.-Z.; Luyengi, L.; Lee, S.K.; Pezzuto, J.M.; Farnsworth, N.R.; Thompson, L.U.; Fong, H.H.S. Isolation and Characterization of Flaxseed (Linum usitatissimum) Constituents. Pharm. Biol. 2008, 37, 1-7. [CrossRef]

388. Penalvo, J.L.; Nurmi, T. Application of coulometric electrode array detection to the analysis of isoflavonoids and lignans. J. Pharm. Biomed. Anal. 2006, 41, 1497-1507. [CrossRef] 
389. Eeckhaut, E.; Struijs, K.; Possemiers, S.; Vincken, J.-P.; Keukeleire, D.D.; Verstraete, W. Metabolism of the lignan macromolecule into enterolignans in the gastrointestinal lumen as determined in the simulator of the human intestinal microbial ecosystem. J. Agric. Food Chem. 2008, 56, 4806-4812. [CrossRef] [PubMed]

390. Kilkkinen, A.; Pietinen, P.; Klaukka, T.; Virtamo, J.; Korhonen, P.; Adlercreutz, H. Use of oral antimicrobials decreases serum enterolactone concentration. Am. J. Epidemiol. 2002, 155, 472-477. [CrossRef]

391. Muir, A.D. Flax LignansAnalytical Methods and How They Influence Our Understanding of Biological Activity. J. AOAC Int. 2006, 89, 1147-1157.

392. Mukker, J.K.; Michel, D.; Muir, A.D.; Krol, E.S.; Alcorn, J. Permeability and Conjugative Metabolism of Flaxseed Lignans by Caco-2 Human Intestinal Cells. J. Nat. Prod. 2014, 77, 29-34. [CrossRef]

393. Setchell, K.D.R.; Brown, N.M.; Zimmer-Nechemias, L.; Wolfe, B.; Jha, P.; Heubi, J.E. Metabolism of secoisolariciresinol-diglycoside the dietary precursor to the intestinally derived lignan enterolactone in humans. Food Funct. 2014, 5, 491-501. [CrossRef] [PubMed]

394. Hutchins, A.M.; Lampe, J.W.; Martini, M.C.; Campbell, D.R.; Slavin, J.L. Vegetables, fruits, and legumes: Effect on urinary isoflavonoid phytoestrogen and lignan excretion. J. Am. Diet. Assoc. 1995, 95, 769-774. [CrossRef]

395. Jansen, G.H.E.; Arts, I.C.W.; Nielen, M.W.F.; Müller, M.; Hollman, P.C.H.; Keijer, J. Uptake and metabolism of enterolactone and enterodiol by human colon epithelial cells. Arch. Biochem. Biophys. 2005, 435, 74-82. [CrossRef]

396. Niemeyer, H.B.; Honig, D.; Lange-Böhmer, A.; Jacobs, E.; Kulling, S.E.; Metzler, M. Oxidative Metabolites of the Mammalian Lignans Enterodiol and Enterolactone in Rat Bile and Urine. J. Agric. Food Chem. 2000, 48, 2910-2919. [CrossRef]

397. Jacobs, E.; Metzler, M. Oxidative metabolism of the mammalian lignans enterolactone and enterodiol by rat, pig, and human liver microsomes. J. Agric. Food Chem. 1999, 47, 1071. [CrossRef]

398. Jacobs, E.; Kulling, S.E.; Metzler, M. Novel metabolites of the mammalian lignans enterolactone and enterodiol in human urine. J. Steroid Biochem. Mol. Biol. 1999, 68, 211-218. [CrossRef]

399. Knust, U.; Hull, W.E.; Spiegelhalder, B.; Bartsch, H.; Strowitzki, T.; Owen, R.W. Analysis of enterolignan glucuronides in serum and urine by HPLC-ESI-MS. Food Chem. Toxicol. 2006, 44, 1038-1049. [CrossRef] [PubMed]

400. Dean, B.; Chang, S.; Doss, G.A.; King, C.; Thomas, P.E. Glucuronidation, oxidative metabolism, and bioactivation of enterolactone in rhesus monkeys. Arch. Biochem. Biophys. 2004, 429, 244-251. [CrossRef]

401. Billinsky, J. Oxidative Metabolism and Cytochrome P450 Enzyme Inhibition Potential of Creosote Bush and Flaxseed Lignans; Krol, E., Alcorn, J., Blakley, B., Bandy, B., Janz, D., Siraki, A., Eds.; ProQuest Dissertations Publishing: Saskatoon, SK, Canada, 2009.

402. Jacobs, M.N.; Nolan, G.T.; Hood, S.R. Lignans, bacteriocides and organochlorine compounds activate the human pregnane X receptor (PXR). Toxicol. Appl. Pharmacol. 2005, 209, 123-133. [CrossRef] [PubMed]

403. Kemperman, R.A.; Bolca, S.; Roger, L.C.; Vaughan, E.E. Novel approaches for analysing gut microbes and dietary polyphenols: Challenges and opportunities. Microbiology 2010, 156, 3224-3231. [CrossRef]

404. Laerke, H.N.; Mortensen, M.A.; Hedemann, M.S.; Bach Knudsen, K.E.; Penalvo, J.L.; Adlercreutz, H. Quantitative aspects of the metabolism of lignans in pigs fed fibre-enriched rye and wheat bread. Br. J. Nutr. 2009, 102, 985-994. [CrossRef]

405. Adlercreutz, H.; Hockerstedt, K.; Bannwart, C.; Bloigu, S.; Hamalainen, E.; Fotsis, T.; Ollus, A. Effect of dietary components, including lignans and phytoestrogens, on enterohepatic circulation and liver metabolism of estrogens and on sex hormone binding globulin (SHBG). J. Steroid Biochem. 1987, 27, 1135-1144. [CrossRef]

406. Beaud, D.; Tailliez, P.; Anba-Mondoloni, J. Genetic characterization of the beta-glucuronidase enzyme from a human intestinal bacterium, Ruminococcus gnavus. Microbiology 2005, 151, 2323-2330. [CrossRef] [PubMed]

407. Kitts, D.D.; Yuan, Y.V.; Wijewickreme, A.N.; Thompson, L.U. Antioxidant activity of the flaxseed lignan secoisolariciresinol diglycoside and its mammalian lignan metabolites enterodiol and enterolactone. Mol. Cell Biochem. 1999, 202, 91-100. [CrossRef] [PubMed]

408. Corsini, E.; Dell'Agli, M.; Facchi, A.; De Fabiani, E.; Lucchi, L.; Boraso, M.S.; Marinovich, M.; Galli, C.L. Enterodiol and enterolactone modulate the immune response by acting on nuclear factor-kappaB (NF-kappaB) signaling. J. Agric. Food Chem. 2010, 58, 6678-6684. [CrossRef] [PubMed]

409. Axelson, M.; Setchell, K.D.R. The excretion of lignans in rats - evidence for an intestinal bacterial source for this new group of compounds. FEBS Lett. 1981, 123, 337-342. [CrossRef] 
410. Adlercreutz, H.; Fotsis, T.; Kurzer, M.S.; Wahala, K.; Makela, T.; Hase, T. Isotope dilution gas chromatographic-mass spectrometric method for the determination of unconjugated lignans and isoflavonoids in human feces, with preliminary results in omnivorous and vegetarian women. Anal. Biochem. 1995, 225, 101-108. [CrossRef]

411. Adlercreutz, H.; Fotsis, T.; Lampe, J.; Wähälä, K.; Mäkelä, T.; Brunow, G.; Hase, T. Quantitative Determination of Lignans and Isoflavonoids in Plasma of Omnivorous and Vegetarian Women by Isotope Dilution Gas Chromatograph $\gamma$-Mass Spectrometry. Scand. J. Clin. Lab. Investig. 1993, 53, 5-18. [CrossRef]

412. Bach Knudsen, K.E.; Serena, A.; Kjaer, A.K.; Tetens, I.; Heinonen, S.M.; Nurmi, T.; Adlercreutz, H. Rye bread in the diet of pigs enhances the formation of enterolactone and increases its levels in plasma, urine and feces. J. Nutr. 2003, 133, 1368-1375. [CrossRef]

413. Raffaelli, B.; Hoikkala, A.; Leppala, E.; Wahala, K. Enterolignans. J. Chromatogr. B Anal. Technol. Biomed. Life Sci. 2002, 777, 29-43. [CrossRef]

414. Axelson, M.; Setchell, K.D. Conjugation of lignans in human urine. FEBS Lett. 1980, 122, 49-53. [CrossRef]

415. Adlercreutz, H.; Honjo, H.; Higashi, A.; Fotsis, T.; Hamalainen, E.; Hasegawa, T.; Okada, H. Urinary excretion of lignans and isoflavonoid phytoestrogens in Japanese men and women consuming a traditional Japanese diet. Am. J. Clin. Nutr. 1991, 54, 1093-1100. [CrossRef] [PubMed]

416. Nurmi, T.; Mursu, J.; Penalvo, J.L.; Poulsen, H.E.; Voutilainen, S. Dietary intake and urinary excretion of lignans in Finnish men. Br. J. Nutr. 2010, 103, 677-685. [CrossRef] [PubMed]

417. Adlercreutz, H.; Fotsis, T.; Heikkinen, R.; Dwyer, J.T.; Woods, M.; Goldin, B.R.; Gorbach, S.L. Excretion of the lignans enterolactone and enterodiol and of equol in omnivorous and vegetarian postmenopausal women and in women with breast cancer. Lancet 1982, 2, 1295-1299. [CrossRef]

418. Smeds, A.I.; Willfor, S.M.; Pietarinen, S.P.; Peltonen-Sainio, P.; Reunanen, M.H. Occurrence of "mammalian" lignans in plant and water sources. Planta 2007, 226, 639-646. [CrossRef] [PubMed]

419. Kuhnle, G.G.; Dell'Aquila, C.; Aspinall, S.M.; Runswick, S.A.; Mulligan, A.A.; Bingham, S.A. Phytoestrogen content of foods of animal origin: Dairy products, eggs, meat, fish, and seafood. J. Agric. Food Chem. 2008, 56, 10099-10104. [CrossRef]

420. Gagnon, N.; Cortes, C.; da Silva, D.; Kazama, R.; Benchaar, C.; dos Santos, G.; Zeoula, L.; Petit, H.V. Ruminal metabolism of flaxseed (Linum usitatissimum) lignans to the mammalian lignan enterolactone and its concentration in ruminal fluid, plasma, urine and milk of dairy cows. Br. J. Nutr. 2009, 102, 1015-1023. [CrossRef]

421. Kilkkinen, A.; Stumpf, K.; Pietinen, P.; Valsta, L.M.; Tapanainen, H.; Adlercreutz, H. Determinants of serum enterolactone concentration. Am. J. Clin. Nutr. 2001, 73, 1094-1100. [CrossRef]

422. Vanharanta, M.; Voutilainen, S.; Nurmi, T.; Kaikkonen, J.; Roberts, L.J.; Morrow, J.D.; Adlercreutz, H.; Salonen, J.T. Association between low serum enterolactone and increased plasma F2-isoprostanes, a measure of lipid peroxidation. Atherosclerosis 2002, 160, 465-469. [CrossRef]

423. Bhakta, D.; Higgins, C.D.; Sevak, L.; Mangtani, P.; Adlercreutz, H.; McMichael, A.J.; dos Santos Silva, I. Phyto-oestrogen intake and plasma concentrations in South Asian and native British women resident in England. Br. J. Nutr. 2006, 95, 1150-1158. [CrossRef]

424. Morton, M.S.; Chan, P.S.; Cheng, C.; Blacklock, N.; Matos-Ferreira, A.; Abranches-Monteiro, L.; Correia, R.; Lloyd, S.; Griffiths, K. Lignans and isoflavonoids in plasma and prostatic fluid in men: Samples from Portugal, Hong Kong, and the United Kingdom. Prostate 1997, 32, 122-128. [CrossRef]

425. Damdimopoulou, P.; Nurmi, T.; Salminen, A.; Damdimopoulos, A.E.; Kotka, M.; van der Saag, P.; Strauss, L.; Poutanen, M.; Pongratz, I.; Makela, S. A single dose of enterolactone activates estrogen signaling and regulates expression of circadian clock genes in mice. J. Nutr. 2011, 141, 1583-1589. [CrossRef] [PubMed]

426. Jan, K.C.; Chang, Y.W.; Hwang, L.S.; Ho, C.T. Tissue distribution and cytochrome P450 inhibition of sesaminol and its tetrahydrofuranoid metabolites. J. Agric. Food Chem. 2012, 60, 8616-8623. [CrossRef] [PubMed]

427. Boccardo, F.; Lunardi, G.L.; Petti, A.R.; Rubagotti, A. Enterolactone in breast cyst fluid: Correlation with EGF and breast cancer risk. Breast Cancer Res. Treat. 2003, 79, 17-23. [CrossRef] [PubMed]

428. Gagnon, N.; Cortes, C.; Petit, H.V. Weekly excretion of the mammalian lignan enterolactone in milk of dairy cows fed flaxseed meal. J. Dairy Res. 2009, 76, 455-458. [CrossRef]

429. Rickard, S.E.; Thompson, L.U. Chronic exposure to secoisolariciresinol diglycoside alters lignan disposition in rats. J. Nutr. 1998, 128, 615-623. [CrossRef] 
430. DeSilva, S.F. Albumin Permeability in Experimental Brain Metastases of Breast Cancer and the Differential Effects on Astrocytes, Neurons, and Metastatic Tumor Cells. Master's Thesis, West Texas A \& M University, Canyon, TX, USA, 2012.

431. Lockman, P.R.; Mittapalli, R.K.; Taskar, K.S.; Rudraraju, V.; Gril, B.; Bohn, K.A.; Adkins, C.E.; Roberts, A.; Thorsheim, H.R.; Gaasch, J.A.; et al. Heterogeneous blood-tumor barrier permeability determines drug efficacy in experimental brain metastases of breast cancer. Clin. Cancer Res. 2010, 16, 5664-5678. [CrossRef] [PubMed]

432. Adkins, C.E.; Mohammad, A.S.; Terrell-Hall, T.B.; Dolan, E.L.; Shah, N.; Sechrest, E.; Griffith, J.; Lockman, P.R. Characterization of passive permeability at the blood-tumor barrier in five preclinical models of brain metastases of breast cancer. Clin. Exp. Metast. 2016, 33, 373-383. [CrossRef]

433. Merlot, A.M.; Kalinowski, D.S.; Richardson, D.R. Unraveling the mysteries of serum albumin-more than just a serum protein. Front. Physiol. 2014, 5, 299. [CrossRef]

434. Miele, E.; Spinelli, G.P.; Miele, E.; Tomao, F.; Tomao, S. Albumin-bound formulation of paclitaxel (Abraxane $\left({ }^{\circledR}\right)$ ABI-007) in the treatment of breast cancer. Int. J. Nanomed. 2009, 4, 99-105.

435. Almousa, M.A.; Krol, E.; Alcorn, J. Enterolactone-glucuronide upregulates Insulin Induced Gene-1 (INSIG-1) to modulate cholesterol metabolism in Caco-2 cells. In Proceedings of the Canadian Society for Pharmaceutical Sciences (CSPS) 20th Annual Symposium, Montreal, QC, Canada, 22-27 May 2019.

436. Perez-Vizcaino, F.; Duarte, J.; Santos-Buelga, C. The flavonoid paradox: Conjugation and deconjugation as key steps for the biological activity of flavonoids. J. Sci. Food Agric. 2012, 92, 1822-1825. [CrossRef]

437. Sperker, B.; Werner, U.; Murdter, T.E.; Tekkaya, C.; Fritz, P.; Wacke, R.; Adam, U.; Gerken, M.; Drewelow, B.; Kroemer, H.K. Expression and function of beta-glucuronidase in pancreatic cancer: Potential role in drug targeting. Naunyn Schmiedebergs Arch. Pharmacol. 2000, 362, 110-115. [CrossRef] [PubMed]

438. Sperker, B.; Backman, J.T.; Kroemer, H.K. The role of $\beta$-glucuronidase in drug disposition and drug targeting in humans. Clin. Pharmacokinet. 1997, 33, 18-31. [CrossRef] [PubMed]

439. Kim, D.H.; Jin, Y.H. Intestinal bacterial beta-glucuronidase activity of patients with colon cancer. Arch. Pharm. Res. 2001, 24, 564-567. [CrossRef] [PubMed]

440. Fishman, W.H.; Anlyan, A.J. The presence of high beta-glucuronidase activity in cancer tissue. J. Biol. Chem. 1947, 169, 449. [PubMed]

441. Menendez, C.; Duenas, M.; Galindo, P.; Gonzalez-Manzano, S.; Jimenez, R.; Moreno, L.; Zarzuelo, M.J.; Rodriguez-Gomez, I.; Duarte, J.; Santos-Buelga, C.; et al. Vascular deconjugation of quercetin glucuronide: The flavonoid paradox revealed? Mol. Nutr. Food Res. 2011, 55, 1780-1790. [CrossRef] [PubMed]

442. Vore, M.; Hoffman, T. Carrier-mediated electrogenic transport of estradiol-17 beta-glucuronide in rat liver BMV. Am. J. Physiol. 1994, 267, G546-G551. [CrossRef]

443. Teiten, M.H.; Eifes, S.; Dicato, M.; Diederich, M. Curcumin-the paradigm of a multi-target natural compound with applications in cancer prevention and treatment. Toxins 2010, 2, 128-162. [CrossRef]

444. Farrand, L.; Oh, S.W.; Song, Y.S.; Tsang, B.K. Phytochemicals: A multitargeted approach to gynecologic cancer therapy. Biomed. Res. Int. 2014, 2014, 890141. [CrossRef]

445. Thomasset, S.C.; Berry, D.P.; Garcea, G.; Marczylo, T.; Steward, W.P.; Gescher, A.J. Dietary polyphenolic phytochemicals-Promising cancer chemopreventive agents in humans? A review of their clinical properties. Int. J. Cancer 2007, 120, 451-458. [CrossRef] [PubMed]

446. Pan, C.L.; Baum, P.D.; Gu, M.; Jorgensen, E.M.; Clark, S.G.; Garriga, G.C. elegans AP-2 and retromer control Wnt signaling by regulating mig-14/Wntless. Dev. Cell 2008, 14, 132-139. [CrossRef] [PubMed]

447. Martinchik, A.N.; Baturin, A.K.; Zubtsov, V.V.; Molofeev, V. Nutritional value and functional properties of flaxseed. Vopr. Pitan. 2012, 81, 4-10. [PubMed]

448. Bylund, A.; Zhang, J.X.; Bergh, A.; Damber, J.E.; Widmark, A.; Johansson, A.; Adlercreutz, H.; Aman, P.; Shepherd, M.J.; Hallmans, G. Rye bran and soy protein delay growth and increase apoptosis of human LNCaP prostate adenocarcinoma in nude mice. Prostate 2000, 42, 304-314. [CrossRef]

449. Landstrom, M.; Zhang, J.X.; Hallmans, G.; Aman, P.; Bergh, A.; Damber, J.E.; Mazur, W.; Wahala, K.; Adlercreutz, H. Inhibitory effects of soy and rye diets on the development of Dunning R3327 prostate adenocarcinoma in rats. Prostate 1998, 36, 151-161. [CrossRef]

450. Lin, X.; Gingrich, J.R.; Bao, W.; Li, J.; Haroon, Z.A.; Demark-Wahnefried, W. Effect of flaxseed supplementation on prostatic carcinoma in transgenic mice. Urology 2002, 60, 919-924. [CrossRef] 
451. Bergman Jungestrom, M.; Thompson, L.U.; Dabrosin, C. Flaxseed and its lignans inhibit estradiol-induced growth, angiogenesis, and secretion of vascular endothelial growth factor in human breast cancer xenografts in vivo. Clin. Cancer Res. 2007, 13, 1061-1067. [CrossRef]

452. Buck, K.; Vrieling, A.; Zaineddin, A.K.; Becker, S.; Hüsing, A.; Kaaks, R.; Linseisen, J.; Flesch-Janys, D.; Chang-Claude, J. Serum Enterolactone and Prognosis of Postmenopausal Breast Cancer. J. Clin. Oncol. 2011, 29, 3730-3738. [CrossRef]

453. Schroder, L.; Richter, D.U.; Piechulla, B.; Chrobak, M.; Kuhn, C.; Schulze, S.; Abarzua, S.; Jeschke, U.; Weissenbacher, T. Effects of Phytoestrogen Extracts Isolated from Elder Flower on Hormone Production and Receptor Expression of Trophoblast Tumor Cells JEG-3 and BeWo, as well as MCF7 Breast Cancer Cells. Nutrients 2016, 8, 616. [CrossRef]

454. Guglielmini, P.; Rubagotti, A.; Boccardo, F. Serum enterolactone levels and mortality outcome in women with early breast cancer: A retrospective cohort study. Breast Cancer Res. Treat. 2012, 132, 661-668. [CrossRef]

455. Olsen, A.; Christensen, J.; Knudsen, K.E.; Johnsen, N.F.; Overvad, K.; Tjonneland, A. Prediagnostic plasma enterolactone levels and mortality among women with breast cancer. Breast Cancer Res. Treat. 2011, 128, 883-889. [CrossRef] [PubMed]

456. Sonestedt, E.; Ivarsson, M.I.; Harlid, S.; Ericson, U.; Gullberg, B.; Carlson, J.; Olsson, H.; Adlercreutz, H.; Wirfalt, E. The protective association of high plasma enterolactone with breast cancer is reasonably robust in women with polymorphisms in the estrogen receptor alpha and beta genes. J. Nutr. 2009, 139, 993-1001. [CrossRef] [PubMed]

457. Martinchik, A.N.; Zubtsov, V.V. Phytoestrogenis properties of flaxseed lignans. Vopr. Pitan. 2012, 81, 61-66.

458. Viveky, N.; Thorpe, L.; Alcorn, J.; Hadjistavropoulos, T.; Whiting, S. Safety evaluation of flaxseed lignan supplementation in older adults residing in long-term care homes. JNHR-J. Nurs. Home Res. 2015, 1, 84-88.

459. Hemmings, S.J.; Westcott, N.; Muir, A.; Czechowicz, D. The effects of dietary flaxseed on the Fischer 344 rat: II. Liver gamma-glutamyltranspeptidase activity. Cell. Biochem. Funct. 2004, 22, 225-231. [CrossRef]

460. Prasad, K. Effect of chronic administration of lignan complex isolated from flaxseed on the hemopoietic system. Mol. Cell. Biochem. 2005, 270, 139-145. [CrossRef] [PubMed]

461. Woo, G. Secoisolariciresinol Diglucoside Effects in Diet-Induced Hyperlipidemic Rats. Ph.D. Thesis, University of Saskatchewan, Saskatchewan, SK, Canada, 2006.

462. Ward, W.E.; Jiang, F.O.; Thompson, L.U. Exposure to flaxseed or purified lignan during lactation influences rat mammary gland structures. Nutr. Cancer 2000, 37, 187-192. [CrossRef] [PubMed]

463. Tou, J.C.; Chen, J.; Thompson, L.U. Flaxseed and its lignan precursor, secoisolariciresinol diglycoside, affect pregnancy outcome and reproductive development in rats. J. Nutr. 1998, 128, 1861-1868. [CrossRef]

464. Ward, W.E.; Chen, J.; Thompson, L.U. Exposure to flaxseed or its purified lignan during suckling only or continuously does not alter reproductive indices in male and female offspring. J. Toxicol. Environ. health part A 2001, 64, 567-577. [CrossRef]

465. Collins, T.F.; Sprando, R.L.; Black, T.N.; Olejnik, N.; Wiesenfeld, P.W.; Babu, U.S.; Bryant, M.; Flynn, T.J.; Ruggles, D.I. Effects of flaxseed and defatted flaxseed meal on reproduction and development in rats. Food Chem. Toxicol. 2003, 41, 819-834. [CrossRef]

466. Tang, R.; Chen, M.; Zhou, K.; Chen, D.; Yu, J.; Hu, W.; Song, L.; Hang, B.; Wang, X.; Xia, Y. Prenatal lignan exposures, pregnancy urine estrogen profiles and birth outcomes. Environ. Pollut. 2015, 205, 261-268. [CrossRef] [PubMed]

467. Liu, H.; Liu, J.; Wang, S.; Zeng, Z.; Li, T.; Liu, Y.; Mastriani, E.; Li, Q.H.; Bao, H.X.; Zhou, Y.J.; et al. Enterolactone has stronger effects than enterodiol on ovarian cancer. J. Ovarian Res. 2017, 10, 49. [CrossRef]

468. Hutchins, A.M.; Martini, M.C.; Olson, B.A.; Thomas, W.; Slavin, J.L. Flaxseed influences urinary lignan excretion in a dose-dependent manner in postmenopausal women. Cancer Epidemiol. Biomark. Prev. 2000, 9, 1113-1118.

469. Pietinen, P.; Stumpf, K.; Mannisto, S.; Kataja, V.; Uusitupa, M.; Adlercreutz, H. Serum enterolactone and risk of breast cancer: A case-control study in eastern Finland. Cancer Epidemiol. Biomark. Prev. 2001, 10, 339-344.

470. Shavers, V.L.; Underwood, W.; Moser, R.P. Race/ethnicity and the perception of the risk of developing prostate cancer. Am. J. Prev. Med. 2009, 37, 64-67. [CrossRef]

471. Azrad, M.; Vollmer, R.T.; Madden, J.; Dewhirst, M.; Polascik, T.J.; Snyder, D.C.; Ruffin, M.T.; Moul, J.W.; Brenner, D.E.; Demark-Wahnefried, W. Flaxseed-derived enterolactone is inversely associated with tumor cell proliferation in men with localized prostate cancer. J. Med. Food 2013, 16, 357-360. [CrossRef] 
472. Heald, C.L.; Ritchie, M.R.; Bolton-Smith, C.; Morton, M.S.; Alexander, F.E. Phyto-oestrogens and risk of prostate cancer in Scottish men. Br. J. Nutr. 2007, 98, 388-396. [CrossRef] [PubMed]

473. McCann, S.E.; Ambrosone, C.B.; Moysich, K.B.; Brasure, J.; Marshall, J.R.; Freudenheim, J.L.; Wilkinson, G.S.; Graham, S. Intakes of selected nutrients, foods, and phytochemicals and prostate cancer risk in western New York. Nutr. Cancer 2005, 53, 33-41. [CrossRef]

474. Bylund, A.; Lundin, E.; Zhang, J.X.; Nordin, A.; Kaaks, R.; Stenman, U.H.; Aman, P.; Adlercreutz, H.; Nilsson, T.K.; Hallmans, G.; et al. Randomised controlled short-term intervention pilot study on rye bran bread in prostate cancer. Eur. J. Cancer Prev. 2003, 12, 407-415. [CrossRef]

475. Buck, K.; Zaineddin, A.K.; Vrieling, A.; Linseisen, J.; Chang-Claude, J. Meta-analyses of lignans and enterolignans in relation to breast cancer risk. Am. J. Clin. Nutr. 2010, 92, 141-153. [CrossRef]

476. Velentzis, L.S.; Cantwell, M.M.; Cardwell, C.; Keshtgar, M.R.; Leathem, A.J.; Woodside, J.V. Lignans and breast cancer risk in pre- and post-menopausal women: Meta-analyses of observational studies. Br. J. Cancer 2009, 100, 1492-1498. [CrossRef] [PubMed]

477. Grosso, G.; Micek, A.; Godos, J.; Pajak, A.; Sciacca, S.; Galvano, F.; Giovannucci, E.L. Dietary Flavonoid and Lignan Intake and Mortality in Prospective Cohort Studies: Systematic Review and Dose-Response Meta-Analysis. Am. J. Epidemiol. 2017, 185, 1304-1316. [CrossRef]

478. Horn-Ross, P.L. Phytoestrogen Consumption and Breast Cancer Risk in a Multiethnic Population: The Bay Area Breast Cancer Study. Am. J. Epidemiol. 2001, 154, 434-441. [CrossRef] [PubMed]

479. Verheus, M.; van Gils, C.H.; Keinan-Boker, L.; Grace, P.B.; Bingham, S.A.; Peeters, P.H. Plasma phytoestrogens and subsequent breast cancer risk. J. Clin. Oncol. 2007, 25, 648-655. [CrossRef] [PubMed]

480. Ward, H.; Chapelais, G.; Kuhnle, G.G.; Luben, R.; Khaw, K.T.; Bingham, S.; European Prospective into Cancer-Norfolk, c. Breast cancer risk in relation to urinary and serum biomarkers of phytoestrogen exposure in the European Prospective into Cancer-Norfolk cohort study. Breast Cancer Res. 2008, 10, R32. [CrossRef] [PubMed]

481. Chang, H.; Yao, S.; Tritchler, D.; Hullar, M.A.; Lampe, J.W.; Thompson, L.U.; McCann, S.E. Genetic Variation in Steroid and Xenobiotic Metabolizing Pathways and Enterolactone Excretion Before and After Flaxseed Intervention in African American and European American Women. Cancer Epidemiol. Biomark. Prev. 2019, 28, 265-274. [CrossRef]

482. Tu, H.; Wen, C.P.; Tsai, S.P.; Chow, W.-H.; Wen, C.; Ye, Y.; Zhao, H.; Tsai, M.K.; Huang, M.; Dinney, C.P.; et al. Cancer risk associated with chronic diseases and disease markers: Prospective cohort study. BMJ 2018, 360, k134. [CrossRef] [PubMed]

483. Rao Kondapally Seshasai, S.; Kaptoge, S.; Thompson, A.; Di Angelantonio, E.; Gao, P.; Sarwar, N.; Whincup, P.H.; Mukamal, K.J.; Gillum, R.F.; Holme, I.; et al. Diabetes mellitus, fasting glucose, and risk of cause-specific death. N. Engl. J. Med. 2011, 364, 829-841. [CrossRef]

484. Jee, S.H.; Ohrr, H.; Sull, J.W.; Yun, J.E.; Ji, M.; Samet, J.M. Fasting serum glucose level and cancer risk in Korean men and women. JAMA 2005, 293, 194-202. [CrossRef]

485. Giovannucci, E.; Harlan, D.M.; Archer, M.C.; Bergenstal, R.M.; Gapstur, S.M.; Habel, L.A.; Pollak, M.; Regensteiner, J.G.; Yee, D. Diabetes and cancer: A consensus report. CA Cancer J. Clin. 2010, 60, 207-221. [CrossRef]

486. Song, Y.M.; Sung, J.; Kim, J.S. Which cholesterol level is related to the lowest mortality in a population with low mean cholesterol level: A 6.4-year follow-up study of 482,472 Korean men. Am. J. Epidemiol. 2000, 151, 739-747. [CrossRef]

487. Strohmaier, S.; Edlinger, M.; Manjer, J.; Stocks, T.; Bjorge, T.; Borena, W.; Haggstrom, C.; Engeland, A.; Nagel, G.; Almquist, M.; et al. Total serum cholesterol and cancer incidence in the Metabolic syndrome and Cancer Project (Me-Can). PLoS ONE 2013, 8, e54242. [CrossRef] [PubMed]

488. Schatzkin, A.; Hoover, R.N.; Taylor, P.R.; Ziegler, R.G.; Carter, C.L.; Larson, D.B.; Licitra, L.M. Serum cholesterol and cancer in the NHANES I epidemiologic followup study. National Health and Nutrition Examination Survey. Lancet 1987, 2, 298-301. [CrossRef]

489. Sherwin, R.W.; Wentworth, D.N.; Cutler, J.A.; Hulley, S.B.; Kuller, L.H.; Stamler, J. Serum cholesterol levels and cancer mortality in 361,662 men screened for the Multiple Risk Factor Intervention Trial. JAMA 1987, 257, 943-948. [CrossRef] [PubMed]

490. Iso, H.; Ikeda, A.; Inoue, M.; Sato, S.; Tsugane, S. Serum cholesterol levels in relation to the incidence of cancer: The JPHC study cohorts. Int. J. Cancer 2009, 125, 2679-2686. [CrossRef] 
491. Kitahara, C.M.; Berrington de Gonzalez, A.; Freedman, N.D.; Huxley, R.; Mok, Y.; Jee, S.H.; Samet, J.M. Total cholesterol and cancer risk in a large prospective study in Korea. J. Clin. Oncol. 2011, 29, 1592-1598. [CrossRef] [PubMed]

492. Jouven, X.; Escolano, S.; Celermajer, D.; Empana, J.P.; Bingham, A.; Hermine, O.; Desnos, M.; Perier, M.C.; Marijon, E.; Ducimetiere, P. Heart rate and risk of cancer death in healthy men. PLoS ONE 2011, 6, e21310. [CrossRef] [PubMed]

493. Wannamethee, G.; Shaper, A.G.; Macfarlane, P.W. Heart rate, physical activity, and mortality from cancer and other noncardiovascular diseases. Am. J. Epidemiol. 1993, 137, 735-748. [CrossRef]

494. Stocks, T.; Bjorge, T.; Ulmer, H.; Manjer, J.; Haggstrom, C.; Nagel, G.; Engeland, A.; Johansen, D.; Hallmans, G.; Selmer, R.; et al. Metabolic risk score and cancer risk: Pooled analysis of seven cohorts. Int. J. Epidemiol. 2015, 44, 1353-1363. [CrossRef]

495. Batty, G.D.; Shipley, M.J.; Marmot, M.G.; Davey Smith, G. Blood pressure and site-specific cancer mortality: Evidence from the original Whitehall study. Br. J. Cancer 2003, 89, 1243-1247. [CrossRef]

496. Goon, P.K.; Stonelake, P.S.; Lip, G.Y. Hypertension, anti-hypertensive therapy and neoplasia. Curr. Pharm. Des. 2007, 13, 2539-2544. [CrossRef] [PubMed]

497. Grossman, E.; Messerli, F.H.; Boyko, V.; Goldbourt, U. Is there an association between hypertension and cancer mortality? Am. J. Med. 2002, 112, 479-486. [CrossRef]

498. Stocks, T.; Van Hemelrijck, M.; Manjer, J.; Bjorge, T.; Ulmer, H.; Hallmans, G.; Lindkvist, B.; Selmer, R.; Nagel, G.; Tretli, S.; et al. Blood pressure and risk of cancer incidence and mortality in the Metabolic Syndrome and Cancer Project. Hypertension 2012, 59, 802-810. [CrossRef] [PubMed]

499. Strasak, A.M.; Lang, S.; Kneib, T.; Brant, L.J.; Klenk, J.; Hilbe, W.; Oberaigner, W.; Ruttmann, E.; Kaltenbach, L.; Concin, H.; et al. Use of penalized splines in extended Cox-type additive hazard regression to flexibly estimate the effect of time-varying serum uric acid on risk of cancer incidence: A prospective, population-based study in 78,850 men. Ann. Epidemiol. 2009, 19, 15-24. [CrossRef] [PubMed]

500. Fini, M.A.; Elias, A.; Johnson, R.J.; Wright, R.M. Contribution of uric acid to cancer risk, recurrence, and mortality. Clin. Transl. Med. 2012, 1, 16. [CrossRef]

501. Taghizadeh, N.; Vonk, J.M.; Boezen, H.M. Serum uric acid levels and cancer mortality risk among males in a large general population-based cohort study. Cancer Causes Control 2014, 25, 1075-1080. [CrossRef]

502. Strasak, A.M.; Rapp, K.; Hilbe, W.; Oberaigner, W.; Ruttmann, E.; Concin, H.; Diem, G.; Pfeiffer, K.P.; Ulmer, H. Serum uric acid and risk of cancer mortality in a large prospective male cohort. Cancer Causes Control 2007, 18, 1021-1029. [CrossRef]

503. Strasak, A.M.; Rapp, K.; Hilbe, W.; Oberaigner, W.; Ruttmann, E.; Concin, H.; Diem, G.; Pfeiffer, K.P.; Ulmer, H. The role of serum uric acid as an antioxidant protecting against cancer: Prospective study in more than 28 000 older Austrian women. Ann. Oncol. 2007, 18, 1893-1897. [CrossRef]

504. Stengel, B. Chronic kidney disease and cancer: A troubling connection. J. Nephrol. 2010, 23, 253-262.

505. Lowrance, W.T.; Ordoñez, J.; Udaltsova, N.; Russo, P.; Go, A.S. CKD and the Risk of Incident Cancer. J. Am. Soc. Nephrol. 2014, 25, 2327-2334. [CrossRef]

506. Wong, G.; Hayen, A.; Chapman, J.R.; Webster, A.C.; Wang, J.J.; Mitchell, P.; Craig, J.C. Association of CKD and Cancer Risk in Older People. J. Am. Soc. Nephrol. 2009, 20, 1341-1350. [CrossRef]

507. Weng, P.-H.; Hung, K.-Y.; Huang, H.-L.; Chen, J.-H.; Sung, P.-K.; Huang, K.-C. Cancer-Specific Mortality in Chronic Kidney Disease: Longitudinal Follow-Up of a Large Cohort. Clin. J. Am. Soc. Nephrol. 2011, 6, 1121-1128. [CrossRef]

508. Iff, S.; Craig, J.C.; Turner, R.; Chapman, J.R.; Wang, J.J.; Mitchell, P.; Wong, G. Reduced estimated GFR and cancer mortality. Am. J. Kidney Diseases 2014, 63, 23-30. [CrossRef]

509. Fried, L.F.; Katz, R.; Sarnak, M.J.; Shlipak, M.G.; Chaves, P.H.M.; Jenny, N.S.; Stehman-Breen, C.; Gillen, D.; Bleyer, A.J.; Hirsch, C.; et al. Kidney Function as a Predictor of Noncardiovascular Mortality. J. Am. Soc. Nephrol. 2005, 16, 3728-3735. [CrossRef]

510. Brenner, D.R.; McLaughlin, J.R.; Hung, R.J. Previous lung diseases and lung cancer risk: A systematic review and meta-analysis. PLoS ONE 2011, 6, e17479. [CrossRef]

511. Tomaz Pacheco, J.; Beltrame Daleprame, J.; Teles Boaventura, G. Impact of dietary flaxseed (linum usitatissimum) supplementation on biochemical profile in healthy rats. Nutr. Hosp. 2011, 26, 798-802. [CrossRef] 
512. Dupasquier, C.M.C.; Weber, A.-M.; Ander, B.P.; Rampersad, P.P.; Steigerwald, S.; Wigle, J.T.; Mitchell, R.W.; Kroeger, E.A.; Gilchrist, J.S.C.; Moghadasian, M.M.; et al. Effects of dietary flaxseed on vascular contractile function and atherosclerosis during prolonged hypercholesterolemia in rabbits. Am. J. Physiol.-Heart Circ. Physiol. 2006, 291, H2987-H2996. [CrossRef]

513. Parikh, M.; Pierce, G.N. Dietary flaxseed: What we know and don't know about its effects on cardiovascular disease. Can. J. Physiol. Pharmacol. 2018, 97, 75-81. [CrossRef]

514. Parikh, M.; Netticadan, T.; Pierce, G.N. Flaxseed: Its bioactive components and their cardiovascular benefits. Am. J. Physiol.-Heart Circ. Physiol. 2018, 314, H146-H159. [CrossRef]

515. Ander, B.P.; Weber, A.R.; Rampersad, P.P.; Gilchrist, J.S.; Pierce, G.N.; Lukas, A. Dietary flaxseed protects against ventricular fibrillation induced by ischemia-reperfusion in normal and hypercholesterolemic Rabbits. J. Nutr. 2004, 134, 3250-3256. [CrossRef]

516. Caligiuri, S.P.; Edel, A.L.; Aliani, M.; Pierce, G.N. Flaxseed for hypertension: Implications for blood pressure regulation. Curr. Hypertens. Rep. 2014, 16, 499. [CrossRef]

517. Khalesi, S.; Irwin, C.; Schubert, M. Flaxseed Consumption May Reduce Blood Pressure: A Systematic Review and Meta-Analysis of Controlled Trials. J. Nutr. 2015, 145, 758-765. [CrossRef]

518. Rodriguez-Leyva, D.; Weighell, W.; Edel, A.L.; LaVallee, R.; Dibrov, E.; Pinneker, R.; Maddaford, T.G.; Ramjiawan, B.; Aliani, M.; Guzman, R.; et al. Potent Antihypertensive Action of Dietary Flaxseed in Hypertensive Patients. Hypertension 2013, 62, 1081-1089. [CrossRef]

519. Pan, A.; Sun, J.; Chen, Y.; Ye, X.; Li, H.; Yu, Z.; Wang, Y.; Gu, W.; Zhang, X.; Chen, X.; et al. Effects of a flaxseed-derived lignan supplement in type 2 diabetic patients: A randomized, double-blind, cross-over trial. PLoS ONE 2007, 2, e1148. [CrossRef] [PubMed]

520. Prasad, K. Secoisolariciresinol diglucoside from flaxseed delays the development of type 2 diabetes in Zucker rat. J. Lab. Clin. Med. 2001, 138, 32-39. [CrossRef]

521. Prasad, K. Suppression of phosphoenolpyruvate carboxykinase gene expression by secoisolariciresinol diglucoside (SDG), a new antidiabetic agent. Int. J. Angiol. 2002, 11, 107-109. [CrossRef]

522. Velasquez, M.T.; Bhathena, S.J. Beneficial role of dietary phytoestrogens in obesity and diabetes. The Am. J. Clin. Nutr. 2002, 76, 1191-1201. [CrossRef]

523. Javidi, A.; Mozaffari-Khosravi, H.; Nadjarzadeh, A.; Dehghani, A.; Eftekhari, M.H. The effect of flaxseed powder on insulin resistance indices and blood pressure in prediabetic individuals: A randomized controlled clinical trial. J. Res. Med. Sci. 2016, 21, 70. [CrossRef]

524. Barre, D.E.; Mizier-Barre, K.A.; Stelmach, E.; Hobson, J.; Griscti, O.; Rudiuk, A.; Muthuthevar, D. Flaxseed Lignan Complex Administration in Older Human Type 2 Diabetics Manages Central Obesity and Prothrombosis-An Invitation to Further Investigation into Polypharmacy Reduction. J. Nutr. Metab. 2012, 2012, 7. [CrossRef]

525. Soltanian, N.; Janghorbani, M. A randomized trial of the effects of flaxseed to manage constipation, weight, glycemia, and lipids in constipated patients with type 2 diabetes. Nutr. Metab. 2018, 15, 36. [CrossRef]

526. Raeisi-Dehkordi, H.; Mohammadi-Sartang, M.; Mazloom, Z.; Barati-Boldaji, R.; Sohrabi, Z. Flaxseed supplementation on glucose control and insulin sensitivity: A systematic review and meta-analysis of 25 randomized, placebo-controlled trials. Nutr. Rev. 2017, 76, 125-139. [CrossRef]

527. Caligiuri, S.P.; Aukema, H.M.; Ravandi, A.; Pierce, G.N. Elevated levels of pro-inflammatory oxylipins in older subjects are normalized by flaxseed consumption. Exp. Gerontol. 2014, 59, 51-57. [CrossRef]

528. Dupasquier, C.M.C.; Dibrov, E.; Kneesh, A.L.; Cheung, P.K.M.; Lee, K.G.Y.; Alexander, H.K.; Yeganeh, B.K.; Moghadasian, M.H.; Pierce, G.N. Dietary flaxseed inhibits atherosclerosis in the LDL receptor-deficient mouse in part through antiproliferative and anti-inflammatory actions. Am. J. Physiolo.-Heart Circ. Physiol. 2007, 293, H2394-H2402. [CrossRef]

529. Prasad, K. Dietary flax seed in prevention of hypercholesterolemic atherosclerosis. Atherosclerosis 1997, 132, 69-76. [CrossRef]

530. Prasad, K. Antioxidant Activity of Secoisolariciresinol Diglucoside-derived Metabolites, Secoisolariciresinol, Enterodiol, and Enterolactone. Int. J. Angiol. 2000, 9, 220-225. [CrossRef] [PubMed]

531. Carreau, C.; Flouriot, G.; Bennetau-Pelissero, C.; Potier, M. Enterodiol and enterolactone, two major diet-derived polyphenol metabolites have different impact on $\mathrm{ER} \alpha$ transcriptional activation in human breast cancer cells. J. Steroid Biochem. Mol. Biol. 2008, 110, 176-185. [CrossRef] [PubMed] 
532. Hu, C.; Yuan, Y.V.; Kitts, D.D. Antioxidant activities of the flaxseed lignan secoisolariciresinol diglucoside, its aglycone secoisolariciresinol and the mammalian lignans enterodiol and enterolactone in vitro. Food Chem. Toxicol. 2007, 45, 2219-2227. [CrossRef] [PubMed]

533. Tülüce, Y.; Özkol, H.; Koyuncu, İ. Photoprotective effect of flax seed oil (Linum usitatissimum L.) against ultraviolet C-induced apoptosis and oxidative stress in rats. Toxicol. Ind. Health 2012, 28, 99-107. [CrossRef] [PubMed]

534. Faseehuddin Shakir, K.A.; Madhusudhan, B. Effects of flaxseed (Linum usitatissimum) chutney on gamma-glutamyl transpeptidase and micronuclei profile in azoxymethane treated rats. Indian J. Clin. Biochem. IJCB 2007, 22, 129-131. [CrossRef]

535. Shakir, K.A.; Madhusudhan, B. Hypocholesterolemic and hepatoprotective effects of flaxseed chutney: Evidence from animal studies. Indian J. Clin. Biochem. IJCB 2007, 22, 117-121. [CrossRef]

536. Sacco, S.M.; Thompson, L.U.; Ganss, B.; Ward, W.E. Accessibility of (3)H-secoisolariciresinol diglycoside lignan metabolites in skeletal tissue of ovariectomized rats. J. Med. Food 2011, 14, 1208-1214. [CrossRef] [PubMed]

537. Prasad, K. Flax lignan complex slows down the progression of atherosclerosis in hyperlipidemic rabbits. J. Cardiovasc. Pharmacol. Ther. 2009, 14, 38-48. [CrossRef] [PubMed]

538. Dzuvor, C.K.O.; Taylor, J.T.; Acquah, C.; Pan, S.; Agyei, D. Bioprocessing of Functional Ingredients from Flaxseed. Molecules 2018, 23, 2444. [CrossRef] [PubMed]

539. Saini, A.; Harjai, K.; Mohan, H.; Punia, R.P.; Chhibber, S. Long-term flaxseed oil supplementation diet protects BALB/c mice against Streptococcus pneumoniae infection. Med. Microbiol. Immunol. 2010, 199, 27-34. [CrossRef]

540. Spence, J.D.; Thornton, T.; Muir, A.D.; Westcott, N.D. The effect of flax seed cultivars with differing content of alpha-linolenic acid and lignans on responses to mental stress. J. Am. Coll. Nutr. 2003, 22, 494-501. [CrossRef] [PubMed]

541. Pistollato, F.; Sumalla Cano, S.; Elio, I.; Masias Vergara, M.; Giampieri, F.; Battino, M. Associations between Sleep, Cortisol Regulation, and Diet: Possible Implications for the Risk of Alzheimer Disease. Adv. Nutr. 2016, 7, 679-689. [CrossRef] [PubMed]

542. Ma, X.; Wang, R.; Zhao, X.; Zhang, C.; Sun, J.; Li, J.; Zhang, L.; Shao, T.; Ruan, L.; Chen, L.; et al. Antidepressant-like effect of flaxseed secoisolariciresinol diglycoside in ovariectomized mice subjected to unpredictable chronic stress. Metab. Brain Disease 2013, 28, 77-84. [CrossRef]

543. Hu, P.; Mei, Q.Y.; Ma, L.; Cui, W.G.; Zhou, W.H.; Zhou, D.S.; Zhao, Q.; Xu, D.Y.; Zhao, X.; Lu, Q.; et al. Secoisolariciresinol diglycoside, a flaxseed lignan, exerts analgesic effects in a mouse model of type 1 diabetes: Engagement of antioxidant mechanism. Eur. J. Pharmacol. 2015, 767, 183-192. [CrossRef]

544. McCann, S.E.; Edge, S.B.; Hicks, D.G.; Thompson, L.U.; Morrison, C.D.; Fetterly, G.; Andrews, C.; Clark, K.; Wilton, J.; Kulkarni, S. A pilot study comparing the effect of flaxseed, aromatase inhibitor, and the combination on breast tumor biomarkers. Nutr. Cancer 2014, 66, 566-575. [CrossRef] [PubMed]

545. Thompson, L.U.; Seidl, M.M.; Rickard, S.E.; Orcheson, L.J.; Fong, H.H. Antitumorigenic effect of a mammalian lignan precursor from flaxseed. Nutr. Cancer 1996, 26, 159-165. [CrossRef]

546. Chen, J.; Tan, K.P.; Ward, W.E.; Thompson, L.U. Exposure to flaxseed or its purified lignan during suckling inhibits chemically induced rat mammary tumorigenesis. Exp. Biol. Med. 2003, 228, 951-958. [CrossRef]

547. Devaraj, S.; Hemarajata, P.; Versalovic, J. The human gut microbiome and body metabolism: Implications for obesity and diabetes. Clin. Chem. 2013, 59, 617-628. [CrossRef] [PubMed]

548. Nieuwdorp, M.; Gilijamse, P.W.; Pai, N.; Kaplan, L.M. Role of the microbiome in energy regulation and metabolism. Gastroenterology 2014, 146, 1525-1533. [CrossRef] [PubMed]

549. Arora, T.; Rudenko, O.; Egerod, K.L.; Husted, A.S.; Kovatcheva-Datchary, P.; Akrami, R.; Kristensen, M.; Schwartz, T.W.; Bäckhed, F. Microbial fermentation of flaxseed fibers modulates the transcriptome of GPR41-expressing enteroendocrine cells and protects mice against diet-induced obesity. Am. J. Physiol.-Endocrinol. Metab. 2019, 316, E453-E463. [CrossRef] [PubMed]

550. Vogelstein, B.; Papadopoulos, N.; Velculescu, V.E.; Zhou, S.; Diaz, L.A.; Kinzler, K.W. Cancer Genome Landscapes. Science 2013, 339, 1546-1558. [CrossRef]

551. Bergers, G.; Hanahan, D. Modes of resistance to anti-angiogenic therapy. Nat. Rev. Cancer 2008, 8, $592-603$. [CrossRef] [PubMed] 
552. Block, K. The Block Center Program for Integrative Cancer Treatment. In Life Over Cancer; Random House Publishing Group: New York, NY, USA, 2009; p. 594.

553. Devi, N.S.; Ramanan, M.; Paragi-Vedanthi, P.; Doble, M. Phytochemicals as multi-target inhibitors of the inflammatory pathway- A modeling and experimental study. Biochem. Biophys. Res. Commun. 2017, 484, 467-473. [CrossRef]

554. Thomas, E.; Egon, K. Complex Interactions between Phytochemicals. The Multi-Target Therapeutic Concept of Phytotherapy. Curr. Drug Targets 2011, 12, 122-132. [CrossRef]

555. Wang, H.; Khor, T.O.; Shu, L.; Su, Z.; Fuentes, F.; Lee, J.-H.; Kong, A.-N.T. Plants Against Cancer: A Review on Natural Phytochemicals in Preventing and Treating Cancers and Their Druggability. Anti-Cancer Agents Med. Chem. 2012, 12, 1281-1305. [CrossRef]

556. Lee, K.W.; Bode, A.M.; Dong, Z. Molecular targets of phytochemicals for cancer prevention. Nat. Rev. Cancer 2011, 11, 211-218. [CrossRef]

557. Broad-spectrum Therapy. Available online: http://www.gettingtoknowcancer.org/broad-spectrum_ chemotherapy.php (accessed on 12 December 2017).

558. Bishayee, A. The Inflammation and Liver Cancer. In Inflammation and Cancer; Aggarwal, B.B., Sung, B., Gupta, S.C., Eds.; Springer: Basel, Switzerland, 2014; pp. 401-435. [CrossRef]

559. Muqbil, I.; Bao, G.W.; El-Kharraj, R.; Shah, M.; Mohammad, R.M.; Sarkar, F.H.; Azmi, A.S. Systems and Network Pharmacology Approaches to Cancer Stem Cells Research and Therapy. J. Stem Cell Res. Ther. 2012, 7, 10413. [CrossRef] [PubMed]

560. Teponno, R.B.; Kusari, S.; Spiteller, M. Recent advances in research on lignans and neolignans. Nat. Prod. Rep. 2016, 33, 1044-1092. [CrossRef]

561. Stocker, R.; Perrella, M.A. Heme oxygenase-1: A novel drug target for atherosclerotic diseases? Circulation 2006, 114, 2178-2189. [CrossRef] [PubMed]

562. Kivelä, A.M.; Kansanen, E.; Jyrkkänen, H.-K.; Nurmi, T.; Ylä-Herttuala, S.; Levonen, A.-L. Enterolactone Induces Heme Oxygenase-1 Expression through Nuclear Factor-E2-Related Factor 2 Activation in Endothelial Cells. J. Nutr. 2008, 138, 1263-1268. [CrossRef] [PubMed]

563. Rajesha, J.; Murthy, K.N.; Kumar, M.K.; Madhusudhan, B.; Ravishankar, G.A. Antioxidant potentials of flaxseed by in vivo model. J. Agric. Food Chem. 2006, 54, 3794-3799. [CrossRef] [PubMed]

564. Cortes, C.; Palin, M.F.; Gagnon, N.; Benchaar, C.; Lacasse, P.; Petit, H.V. Mammary gene expression and activity of antioxidant enzymes and concentration of the mammalian lignan enterolactone in milk and plasma of dairy cows fed flax lignans and infused with flax oil in the abomasum. Br. J. Nutr. 2012, 108, 1390-1398. [CrossRef]

565. Lee, J.C.; Krochak, R.; Blouin, A.; Kanterakis, S.; Chatterjee, S.; Arguiri, E.; Vachani, A.; Solomides, C.C.; Cengel, K.A.; Christofidou-Solomidou, M. Dietary flaxseed prevents radiation-induced oxidative lung damage, inflammation and fibrosis in a mouse model of thoracic radiation injury. Cancer Biol. Ther. 2009, 8, 47-53. [CrossRef]

566. Slavova-Kazakova, A.; Karamać, M.; Kancheva, V.; Amarowicz, R. Antioxidant Activity of Flaxseed Extracts in Lipid Systems. Molecules 2016, 21, 17. [CrossRef]

567. Hosseinian, F.S.; Muir, A.D.; Westcott, N.D.; Krol, E.S. Antioxidant capacity of flaxseed lignans in two model systems. J. Am. Oil Chem. Soc. 2006, 83, 835. [CrossRef]

568. Kasote, D. Flaxseed phenolics as natural antioxidants. Int. Food Res. J. 2013, 20, 27.

569. Barthet, V.J.; Klensporf-Pawlik, D.; Przybylski, R. Antioxidant activity of flaxseed meal components. Can. J. Plant Sci. 2014, 94, 593-602. [CrossRef]

570. Cort, A.; Ozben, T.; Saso, L.; De Luca, C.; Korkina, L. Redox Control of Multidrug Resistance and Its Possible Modulation by Antioxidants. Oxid. Med. Cell. Longev. 2016, 2016, 4251912. [CrossRef]

571. Morgan, M.J.; Liu, Z.G. Crosstalk of reactive oxygen species and NF-kappaB signaling. Cell Res. 2011, 21, 103-115. [CrossRef] [PubMed]

572. Morse, D.; Pischke, S.E.; Zhou, Z.; Davis, R.J.; Flavell, R.A.; Loop, T.; Otterbein, S.L.; Otterbein, L.E.; Choi, A.M. Suppression of inflammatory cytokine production by carbon monoxide involves the JNK pathway and AP-1. J. Biol. Chem. 2003, 278, 36993-36998. [CrossRef] [PubMed]

573. Ryu, E.Y.; Park, S.Y.; Kim, S.G.; Park, D.J.; Kang, J.S.; Kim, Y.H.; Seetharaman, R.; Choi, Y.W.; Lee, S.J. Anti-inflammatory effect of heme oxygenase-1 toward Porphyromonas gingivalis lipopolysaccharide in macrophages exposed to gomisins A, G, and J. J. Med. Food 2011, 14, 1519-1526. [CrossRef] [PubMed] 
574. Sawant, S.H.; Bodhankar, S.L. Flax lignan concentrate attenuate hypertension and abnormal left ventricular contractility via modulation of endogenous biomarkers in two-kidney-one-clip (2K1C) hypertensive rats. Revista Brasileira de Farmacognosia 2016, 26, 601-610. [CrossRef]

575. Velalopoulou, A.; Tyagi, S.; Pietrofesa, R.A.; Arguiri, E.; Christofidou-Solomidou, M. The Flaxseed-Derived Lignan Phenolic Secoisolariciresinol Diglucoside (SDG) Protects Non-Malignant Lung Cells from Radiation Damage. Int. J. Mol. Sci. 2015, 17, 7. [CrossRef] [PubMed]

576. Christofidou-Solomidou, M.; Tyagi, S.; Pietrofesa, R.; Dukes, F.; Arguiri, E.; Turowski, J.; Grieshaber, P.A.; Solomides, C.C.; Cengel, K.A. Radioprotective role in lung of the flaxseed lignan complex enriched in the phenolic secoisolariciresinol diglucoside (SDG). Radiat. Res. 2012, 178, 568-580. [CrossRef]

577. Mishra, O.P.; Popov, A.V.; Pietrofesa, R.A.; Christofidou-Solomidou, M. Gamma-irradiation produces active chlorine species (ACS) in physiological solutions: Secoisolariciresinol diglucoside (SDG) scavenges ACS - A novel mechanism of DNA radioprotection. Biochimica et biophysica acta 2016, 1860, 1884-1897. [CrossRef] [PubMed]

578. Mishra, O.P.; Pietrofesa, R.; Christofidou-Solomidou, M. Novel synthetic (S,S) and (R,R)-secoisolariciresinol diglucosides (SDGs) protect naked plasmid and genomic DNA From gamma radiation damage. Radiat. Res. 2014, 182, 102-110. [CrossRef]

579. Braun, S.; Bitton-Worms, K.; LeRoith, D. The Link between the Metabolic Syndrome and Cancer. Int. J. Biol. Sci. 2011, 7, 1003-1015. [CrossRef] [PubMed]

580. Philip, M.; Rowley, D.A.; Schreiber, H. Inflammation as a tumor promoter in cancer induction. Semin. Cancer Biol. 2004, 14, 433-439. [CrossRef] [PubMed]

581. Pietrofesa, R.; Turowski, J.; Tyagi, S.; Dukes, F.; Arguiri, E.; Busch, T.M.; Gallagher-Colombo, S.M.; Solomides, C.C.; Cengel, K.A.; Christofidou-Solomidou, M. Radiation mitigating properties of the lignan component in flaxseed. BMC Cancer 2013, 13, 179. [CrossRef] [PubMed]

582. Pietrofesa, R.A.; Velalopoulou, A.; Arguiri, E.; Menges, C.W.; Testa, J.R.; Hwang, W.T.; Albelda, S.M.; Christofidou-Solomidou, M. Flaxseed lignans enriched in secoisolariciresinol diglucoside prevent acute asbestos-induced peritoneal inflammation in mice. Carcinogenesis 2016, 37, 177-187. [CrossRef] [PubMed]

583. Dikshit, A.; Gomes Filho, M.A.; Eilati, E.; McGee, S.; Small, C.; Gao, C.; Klug, T.; Hales, D.B. Flaxseed reduces the pro-carcinogenic micro-environment in the ovaries of normal hens by altering the PG and oestrogen pathways in a dose-dependent manner. Br. J. Nutr. 2015, 113, 1384-1395. [CrossRef]

584. Christofidou-Solomidou, M.; Pietrofesa, R.; Arguiri, E.; McAlexander, M.A.; Witwer, K.W. Dietary flaxseed modulates the miRNA profile in irradiated and non-irradiated murine lungs: A novel mechanism of tissue radioprotection by flaxseed. Cancer Biol. Ther. 2014, 15, 930-937. [CrossRef] [PubMed]

585. Williams, D.; Verghese, M.; Walker, L.T.; Boateng, J.; Shackelford, L.; Chawan, C.B. Flax seed oil and flax seed meal reduce the formation of aberrant crypt foci (ACF) in azoxymethane-induced colon cancer in Fisher 344 male rats. Food Chem. Toxicol. 2007, 45, 153-159. [CrossRef]

586. Curry, C.; Garcia-Villatoro, E.; Hales, D.B.; Allred, C.D. The Chemoprotective Effects of Mammalian Lignans Enterodiol and Enterolactone in Non-Transformed Colonocytes. FASEB J. 2016, 30, 691.38. [CrossRef]

587. Curry, C.A. Chemoprotective Effects of Flaxseed Lignans Enterodiol and Enterolactone in Non-Transformed Colonocytes. Ph.D. Thesis, Texas A \& M University, College Station, TX, USA, 2015.

588. Awad, K.S. Inhibition of Human Papilloma Virus E6 Oncogene Function by Mammalian Lignans Activates p53 Tumor Supressor Protein and Induces Apoptosis in Cervical Cancer Cells. Ph.D. Thesis, Kent State University, Kent, OH, USA, 2007.

589. Spurgers, K.B.; Coombes, K.R.; Meyn, R.E.; Gold, D.L.; Logothetis, C.J.; Johnson, T.J.; McDonnell, T.J. A comprehensive assessment of p53-responsive genes following adenoviral-p53 gene transfer in Bcl-2-expressing prostate cancer cells. Oncogene 2004, 23, 1712-1723. [CrossRef]

590. Alimirah, F.; Panchanathan, R.; Davis, F.J.; Chen, J.; Choubey, D. Restoration of p53 expression in human cancer cell lines upregulates the expression of Notch1: Implications for cancer cell fate determination after genotoxic stress. Neoplasia 2007, 9, 427-434. [CrossRef]

591. Feig, D.I.; Reid, T.M.; Loeb, L.A. Reactive oxygen species in tumorigenesis. Cancer Res. 1994, 54, 1890s-1894s. [PubMed]

592. Xue, J.Y.; Liu, G.T.; Wei, H.L.; Pan, Y. Antioxidant activity of two dibenzocyclooctene lignans on the aged and ischemic brain in rats. Free Radic. Biol. Med. 1992, 12, 127-135. [CrossRef] 
593. McCann, M.J.; Rowland, I.R.; Roy, N.C. The anti-proliferative effects of enterolactone in prostate cancer cells: Evidence for the role of DNA licencing genes, mi-R106b cluster expression, and PTEN dosage. Nutrients 2014, 6, 4839-4855. [CrossRef] [PubMed]

594. Prasad, K.; Dhar, A. Flaxseed and Diabetes. Curr. Pharm. Des. 2016, 22, 141-144. [CrossRef]

595. Torkan, M.; Entezari, M.H.; Siavash, M. Effect of flaxseed on blood lipid level in hyperlipidemic patients. Rev. Recent Clin. Trials 2015, 10, 61-67. [CrossRef] [PubMed]

596. Almario, R.U.; Karakas, S.E. Lignan content of the flaxseed influences its biological effects in healthy men and women. J. Am. Coll. Nutr. 2013, 32, 194-199. [CrossRef]

597. Ding, E.L.; Hu, F.B. Cancer and cholesterol: Understanding the V-shaped association in patients with diabetes. CMAJ 2008, 179, 403-404. [CrossRef]

598. Radisauskas, R.; Kuzmickiene, I.; Milinaviciene, E.; Everatt, R. Hypertension, serum lipids and cancer risk: A review of epidemiological evidence. Medicina 2016, 52, 89-98. [CrossRef]

599. Vulcan, A.; Manjer, J.; Ohlsson, B. High blood glucose levels are associated with higher risk of colon cancer in men: A cohort study. BMC Cancer 2017, 17, 842. [CrossRef]

600. Ryu, T.Y.; Park, J.; Scherer, P.E. Hyperglycemia as a risk factor for cancer progression. Diabetes Metab. J. 2014, 38, 330-336. [CrossRef]

601. Cui, G.; Zhang, T.; Ren, F.; Feng, W.M.; Yao, Y.; Cui, J.; Zhu, G.L.; Shi, Q.L. High Blood Glucose Levels Correlate with Tumor Malignancy in Colorectal Cancer Patients. Med Sci Monit 2015, 21, 3825-3833. [CrossRef]

602. May-Wilson, S.; Sud, A.; Law, P.J.; Palin, K.; Tuupanen, S.; Gylfe, A.; Hanninen, U.A.; Cajuso, T.; Tanskanen, T.; Kondelin, J.; et al. Pro-inflammatory fatty acid profile and colorectal cancer risk: A Mendelian randomisation analysis. Eur. J. Cancer 2017, 84, 228-238. [CrossRef]

603. Ribas, V.; García-Ruiz, C.; Fernández-Checa, J.C. Mitochondria, cholesterol and cancer cell metabolism. Clin. Transl. Med. 2016, 5, 22. [CrossRef]

604. Kuzu, O.F.; Noory, M.A.; Robertson, G.P. The Role of Cholesterol in Cancer. Cancer Res. 2016, 76, $2063-2070$. [CrossRef] [PubMed]

605. Porporato, P.E.; Filigheddu, N.; Pedro, J.M.B.; Kroemer, G.; Galluzzi, L. Mitochondrial metabolism and cancer. Cell Res. 2018, 28, 265-280. [CrossRef] [PubMed]

606. Beloribi-Djefaflia, S.; Vasseur, S.; Guillaumond, F. Lipid metabolic reprogramming in cancer cells. Oncogenesis 2016, 5, e189. [CrossRef] [PubMed]

607. Drygalski, K.; Berk, K.; Charytoniuk, T.; Ilowska, N.; Lukaszuk, B.; Chabowski, A.; Konstantynowicz-Nowicka, K. Does the enterolactone (ENL) affect fatty acid transporters and lipid metabolism in liver? Nutr. Metab. 2017, 14, 69. [CrossRef]

608. Di, Y.; De Silva, F.; Krol, E.S.; Alcorn, J. Flaxseed Lignans Enhance the Cytotoxicity of Chemotherapeutic Agents against Breast Cancer Cell Lines MDA-MB-231 and SKBR3. Nutr. Cancer 2018, 70, 306-315. [CrossRef] [PubMed]

609. Yoshii, Y.; Furukawa, T.; Oyama, N.; Hasegawa, Y.; Kiyono, Y.; Nishii, R.; Waki, A.; Tsuji, A.B.; Sogawa, C.; Wakizaka, H.; et al. Fatty acid synthase is a key target in multiple essential tumor functions of prostate cancer: Uptake of radiolabeled acetate as a predictor of the targeted therapy outcome. PLoS ONE 2013, 8, e64570. [CrossRef]

610. Fukumitsu, S.; Aida, K.; Ueno, N.; Ozawa, S.; Takahashi, Y.; Kobori, M. Flaxseed lignan attenuates high-fat diet-induced fat accumulation and induces adiponectin expression in mice. Br. J. Nutr. 2008, 100, 669-676. [CrossRef]

611. Rietjens, I.; Louisse, J.; Beekmann, K. The potential health effects of dietary phytoestrogens. Br. J. Pharmacol. 2017, 174, 1263-1280. [CrossRef]

612. Key, T.J. Hormones and cancer in humans. Mutat. Res. 1995, 333, 59-67. [CrossRef]

613. Feitelson, M.A.; Arzumanyan, A.; Kulathinal, R.J.; Blain, S.W.; Holcombe, R.F.; Mahajna, J.; Marino, M.; Martinez-Chantar, M.L.; Nawroth, R.; Sanchez-Garcia, I.; et al. Sustained proliferation in cancer: Mechanisms and novel therapeutic targets. Semin. Cancer Biol. 2015, 35, S25-S54. [CrossRef] [PubMed]

614. Mueller, S.O.; Simon, S.; Chae, K.; Metzler, M.; Korach, K.S. Phytoestrogens and their human metabolites show distinct agonistic and antagonistic properties on estrogen receptor alpha (ERalpha) and ERbeta in human cells. Toxicol. Sci. 2004, 80, 14-25. [CrossRef] 
615. Saarinen, N.M.; Power, K.; Chen, J.; Thompson, L.U. Flaxseed attenuates the tumor growth stimulating effect of soy protein in ovariectomized athymic mice with MCF-7 human breast cancer xenografts. Int. J. Cancer 2006, 119, 925-931. [CrossRef]

616. Chen, J.; Hui, E.; Ip, T.; Thompson, L.U. Dietary flaxseed enhances the inhibitory effect of tamoxifen on the growth of estrogen-dependent human breast cancer (mcf-7) in nude mice. Clin. Cancer Res. 2004, 10, 7703-7711. [CrossRef]

617. Chen, J.; Power, K.A.; Mann, J.; Cheng, A.; Thompson, L.U. Flaxseed alone or in combination with tamoxifen inhibits MCF-7 breast tumor growth in ovariectomized athymic mice with high circulating levels of estrogen. Exp. Biol. Med. 2007, 232, 1071-1080. [CrossRef] [PubMed]

618. Chen, L.H.; Fang, J.; Sun, Z.; Li, H.; Wu, Y.; Demark-Wahnefried, W.; Lin, X. Enterolactone inhibits insulin-like growth factor-1 receptor signaling in human prostatic carcinoma PC-3 cells. J. Nutr. 2009, 139, 653-659. [CrossRef]

619. Rosner, W.; Hryb, D.J.; Khan, M.S.; Nakhla, A.M.; Romas, N.A. Sex hormone-binding globulin mediates steroid hormone signal transduction at the plasma membrane. J. Steroid Biochem. Mol. Biol. 1999, 69, 481-485. [CrossRef]

620. Schottner, M.; Spiteller, G.; Gansser, D. Lignans interfering with 5 alpha-dihydrotestosterone binding to human sex hormone-binding globulin. J. Nat. Prod. 1998, 61, 119-121. [CrossRef] [PubMed]

621. Adlercreutz, H.; Mousavi, Y.; Clark, J.; Hockerstedt, K.; Hamalainen, E.; Wahala, K.; Makela, T.; Hase, T. Dietary phytoestrogens and cancer: In vitro and in vivo studies. J. Steroid Biochem. Mol. Biol. 1992, 41, 331-337. [CrossRef]

622. Shoulars, K.; Rodrigues, M.A.; Crowley, J.R.; Turk, J.; Thompson, T.; Markaverich, B.M. Nuclear type II [3H] estradiol binding sites: A histone H3-H4 complex. J. Steroid Biochem. Mol. Biol. 2005, 96, 19-30. [CrossRef]

623. Shoulars, K.; Brown, T.; Alejandro, M.A.; Crowley, J.; Markaverich, B.M. Identification of nuclear type II [3H] estradiol binding sites as histone H4. Biochem. Biophys. Res. Commun. 2002, 296, 1083-1090. [CrossRef]

624. Brodie, A.M.; Lu, Q.; Long, B.J.; Fulton, A.; Chen, T.; Macpherson, N.; DeJong, P.C.; Blankenstein, M.A.; Nortier, J.W.; Slee, P.H.; et al. Aromatase and COX-2 expression in human breast cancers. J. Steroid Biochem. Mol. Biol. 2001, 79, 41-47. [CrossRef]

625. Poutanen, M.; Isomaa, V.; Lehto, V.P.; Vihko, R. Immunological analysis of $17 \beta$-hydroxysteroid dehydrogenase in benign and malignant human breast tissue. Int. J. Cancer 1992, 50, 386-390. [CrossRef]

626. Evans, B.A.; Griffiths, K.; Morton, M.S. Inhibition of 5 alpha-reductase in genital skin fibroblasts and prostate tissue by dietary lignans and isoflavonoids. J. Endocrinol. 1995, 147, 295-302. [CrossRef]

627. Xiong, X.Y.; Hu, X.J.; Li, Y.; Liu, C.M. Inhibitory Effects of Enterolactone on Growth and Metastasis in Human Breast Cancer. Nutr. Cancer 2015, 67, 1324-1332. [CrossRef]

628. Chikara, S.; Lindsey, K.; Borowicz, P.; Christofidou-Solomidou, M.; Reindl, K.M. Enterolactone alters FAK-Src signaling and suppresses migration and invasion of lung cancer cell lines. BMC Complement. Alternat. Med. 2017, 17, 30. [CrossRef] [PubMed]

629. Peuhu, E.; Rivero-Muller, A.; Stykki, H.; Torvaldson, E.; Holmbom, T.; Eklund, P.; Unkila, M.; Sjoholm, R.; Eriksson, J.E. Inhibition of Akt signaling by the lignan matairesinol sensitizes prostate cancer cells to TRAIL-induced apoptosis. Oncogene 2010, 29, 898-908. [CrossRef] [PubMed]

630. Pavlova, N.N.; Thompson, C.B. The Emerging Hallmarks of Cancer Metabolism. Cell Metab. 2016, 23 , $27-47$. [CrossRef] [PubMed]

631. DeBerardinis, R.J.; Lum, J.J.; Hatzivassiliou, G.; Thompson, C.B. The biology of cancer: Metabolic reprogramming fuels cell growth and proliferation. Cell Metab. 2008, 7, 11-20. [CrossRef]

632. Park, S.Y.; Park, D.J.; Kim, Y.H.; Kim, Y.; Kim, S.G.; Shon, K.J.; Choi, Y.W.; Lee, S.J. Upregulation of heme oxygenase-1 via PI3K/Akt and Nrf-2 signaling pathways mediates the anti-inflammatory activity of Schisandrin in Porphyromonas gingivalis LPS-stimulated macrophages. Immunol. Lett. 2011, 139, 93-101. [CrossRef]

633. Park, S.Y.; Park, D.J.; Kim, Y.H.; Kim, Y.; Choi, Y.W.; Lee, S.J. Schisandra chinensis alpha-iso-cubebenol induces heme oxygenase-1 expression through PI3K/Akt and Nrf2 signaling and has anti-inflammatory activity in Porphyromonas gingivalis lipopolysaccharide-stimulated macrophages. Int. Immunopharmacol. 2011, 11, 1907-1915. [CrossRef] [PubMed] 
634. Chen, L.H.; Fang, J.; Li, H.; Demark-Wahnefried, W.; Lin, X. Enterolactone induces apoptosis in human prostate carcinoma LNCaP cells via a mitochondrial-mediated, caspase-dependent pathway. Mol. Cancer Ther. 2007, 6, 2581-2590. [CrossRef] [PubMed]

635. Gacche, R.N.; Meshram, R.J. Targeting tumor micro-environment for design and development of novel anti-angiogenic agents arresting tumor growth. Prog. Biophys. Mol. Biol. 2013, 113, 333-354. [CrossRef] [PubMed]

636. Zhao, Y.; Adjei, A.A. Targeting Angiogenesis in Cancer Therapy: Moving Beyond Vascular Endothelial Growth Factor. Oncologist 2015, 20, 660-673. [CrossRef]

637. Dimova, I.; Popivanov, G.; Djonov, V. Angiogenesis in cancer-General pathways and their therapeutic implications. J. BUON 2014, 19, 15-21.

638. Azzi, S.; Hebda, J.K.; Gavard, J. Vascular permeability and drug delivery in cancers. Front. Oncol. 2013, 3, 211. [CrossRef]

639. Chen, J.; Wang, L.; Thompson, L.U. Flaxseed and its components reduce metastasis after surgical excision of solid human breast tumor in nude mice. Cancer Lett. 2006, 234, 168-175. [CrossRef] [PubMed]

640. Magee, P.J.; McGlynn, H.; Rowland, I.R. Differential effects of isoflavones and lignans on invasiveness of MDA-MB-231 breast cancer cells in vitro. Cancer Lett. 2004, 208, 35-41. [CrossRef]

641. Bartsch, J.E.; Staren, E.D.; Appert, H.E. Matrix metalloproteinase expression in breast cancer. J. Surg. Res. 2003, 110, 383-392. [CrossRef]

642. Mali, A.V.; Wagh, U.V.; Hegde, M.V.; Chandorkar, S.S.; Surve, S.V.; Patole, M.V. In vitro anti-metastatic activity of enterolactone, a mammalian lignan derived from flax lignan, and down-regulation of matrix metalloproteinases in MCF-7 and MDA MB 231 cell lines. Indian J. Cancer 2012, 49, 181-187. [CrossRef] [PubMed]

643. Mali, A.V.; Joshi, A.A.; Hegde, M.V.; Kadam, S.S. Enterolactone Suppresses Proliferation, Migration and Metastasis of MDA-MB-231 Breast Cancer Cells Through Inhibition of uPA Induced Plasmin Activation and MMPs-Mediated ECM Remodeling. Asian Pac. J. Cancer Prev. APJCP 2017, 18, 905-915. [CrossRef] [PubMed]

644. Kraljevic Pavelic, S.; Sedic, M.; Bosnjak, H.; Spaventi, S.; Pavelic, K. Metastasis: New perspectives on an old problem. Mol. Cancer 2011, 10, 22. [CrossRef] [PubMed]

645. Li, S.; Wang, Y.; Feng, C.; Wu, G.; Ye, Y.; Tian, J. Calycosin Inhibits the Migration and Invasion of Human Breast Cancer Cells by Down-Regulation of Foxp3 Expression. Cell. Physiol. Biochem. 2017, 44, 1775-1784. [CrossRef]

646. Wong, R.S. Apoptosis in cancer: From pathogenesis to treatment. J. Exp. Clin. Cancer Res. 2011, $30,87$. [CrossRef] [PubMed]

647. Mali, A.V.; Joshi, A.A.; Hegde, M.V.; Kadam, S.S. Enterolactone modulates the ERK/NF-кB/Snail signaling pathway in triple-negative breast cancer cell line MDA-MB-231 to revert the TGF- $\beta$-induced epithelial-mesenchymal transition. Cancer Biol. Med. 2018, 15, 137-156. [CrossRef]

648. Zhang, L.Y.; Wang, X.L.; Sun, D.X.; Liu, X.X.; Hu, X.Y.; Kong, F. Regulation of zinc transporters by dietary flaxseed lignan in human breast cancer xenografts. Mol. Biol. Rep. 2008, 35, 595-600. [CrossRef]

649. Lineberger, C.G.; Bowers, L.W.; Ford, N.A.; Rossi, E.L.; Kimler, B.K.; Fabian, C.J.; Hursting, S.D. Abstract 231: The polyphenolic plant lignan secoisolariciresinol diglycoside reduces mammary tumor growth, possibly via inhibition of local inflammatory signaling. Cancer Res. 2017, 77, 231. [CrossRef]

650. Feng, J.; Shi, Z.; Ye, Z. Effects of Metabolites of the Lignans Enterolactone and Enterodiol on Osteoblastic Differentiation of MG-63 Cells. Biol. Pharm. Bull. 2008, 31, 1067-1070. [CrossRef]

651. Ren, G.Y.; Chen, C.Y.; Chen, W.G.; Huang, Y.; Qin, L.Q.; Chen, L.H. The treatment effects of flaxseed-derived secoisolariciresinol diglycoside and its metabolite enterolactone on benign prostatic hyperplasia involve the G protein-coupled estrogen receptor 1. Appl. Physiol. Nutr. Metab. 2016, 41, 1303-1310. [CrossRef]

652. Bommareddy, A.; Zhang, X.; Schrader, D.; Kaushik, R.S.; Zeman, D.; Matthees, D.P.; Dwivedi, C. Effects of dietary flaxseed on intestinal tumorigenesis in Apc(Min) mouse. Nutr. Cancer 2009, 61, 276-283. [CrossRef] [PubMed]

653. Lehraiki, A.; Attoumbre, J.; Bienaime, C.; Matifat, F.; Bensaddek, L.; Nava-Saucedo, E.; Fliniaux, M.A.; Ouadid-Ahidouch, H.; Baltora-Rosset, S. Extraction of lignans from flaxseed and evaluation of their biological effects on breast cancer MCF-7 and MDA-MB-231 cell lines. J. Med. Food 2010, 13, 834-841. [CrossRef] [PubMed] 
654. Aune, D.; Chan, D.S.M.; Lau, R.; Vieira, R.; Greenwood, D.C.; Kampman, E.; Norat, T. Dietary fibre, whole grains, and risk of colorectal cancer: Systematic review and dose-response meta-analysis of prospective studies. BMJ 2011, 343, d6617. [CrossRef] [PubMed]

655. Armstrong, B.; Doll, R. Environmental factors and cancer incidence and mortality in different countries, with special reference to dietary practices. Int. J. Cancer 1975, 15, 617-631. [CrossRef]

656. Kolonel, L.N. Cancer patterns of four ethnic groups in Hawaii. J. Natl. Cancer Inst. 1980, 65, 1127-1139.

657. Kono, S. Secular trend of colon cancer incidence and mortality in relation to fat and meat intake in Japan. Eur. J. Cancer Prev. 2004, 13, 127-132. [CrossRef] [PubMed]

658. Cagan, R.; Meyer, P. Rethinking cancer: Current challenges and opportunities in cancer research. Disease Models Mech. 2017, 10, 349-352. [CrossRef] [PubMed]

659. Molina-Montes, E.; Sánchez, M.-J.; Zamora-Ros, R.; Bueno-de-Mesquita, H.B.A.; Wark, P.A.; Obon-Santacana, M.; Kühn, T.; Katzke, V.; Travis, R.C.; Ye, W.; et al. Flavonoid and lignan intake and pancreatic cancer risk in the European prospective investigation into cancer and nutrition cohort. Int. J. Cancer 2016, 139, 1480-1492. [CrossRef]

660. Mattiello, A.; Hjartåker, A.; Mulligan, A.A.; Tjønneland, A.; Trichopoulou, A.; Agudo, A.; Scalbert, A.; Teucher, B.; Saieva, C.; González, C.A.; et al. Dietary flavonoid and lignan intake and gastric adenocarcinoma risk in the European Prospective Investigation into Cancer and Nutrition (EPIC) study. Am. J. Clin. Nutr. 2012, 96, 1398-1408. [CrossRef]

661. Zamora-Ros, R.; Sacerdote, C.; Ricceri, F.; Weiderpass, E.; Roswall, N.; Buckland, G.; St-Jules, D.E.; Overvad, K.; Kyro, C.; Fagherazzi, G.; et al. Flavonoid and lignan intake in relation to bladder cancer risk in the European Prospective Investigation into Cancer and Nutrition (EPIC) study. Br. J. Cancer 2014, 111, 1870-1880. [CrossRef] [PubMed]

662. Zamora-Ros, R.; Fedirko, V.; Trichopoulou, A.; Gonzalez, C.A.; Bamia, C.; Trepo, E.; Nothlings, U.; Duarte-Salles, T.; Serafini, M.; Bredsdorff, L.; et al. Dietary flavonoid, lignan and antioxidant capacity and risk of hepatocellular carcinoma in the European prospective investigation into cancer and nutrition study. Int. J. Cancer 2013, 133, 2429-2443. [CrossRef] [PubMed]

(C) 2019 by the authors. Licensee MDPI, Basel, Switzerland. This article is an open access article distributed under the terms and conditions of the Creative Commons Attribution (CC BY) license (http://creativecommons.org/licenses/by/4.0/). 